UNIVERSIDADE DE SÃO PAULO

INSTITUTO DE PSICOLOGIA

MARIA CLARA DRUMMOND SOARES DE MOURA

\title{
Alterações atencionais na Distrofia Muscular de Duchenne
}




\section{Alterações atencionais na Distrofia Muscular de Duchenne}

Dissertação apresentada ao Instituto de Psicologia da Universidade de São Paulo para obtenção do título de mestre em Neurociência e Comportamento.

Área de concentração: Neurociências e Comportamento

Orientador: Prof. Dr. Luiz Eduardo Ribeiro do Valle

São Paulo

2009 
AUTORIZO A REPRODUÇÃO E DIVULGAÇÃO TOTAL OU PARCIAL DESTE TRABALHO, POR QUALQUER MEIO CONVENCIONAL OU ELETRÔNICO, PARA FINS DE ESTUDO E PESQUISA, DESDE QUE CITADA A FONTE.

Catalogação na publicação

Serviço de Biblioteca e Documentação

Instituto de Psicologia da Universidade de São Paulo

Moura, Maria Clara Drummond Soares de.

Alterações atencionais na distrofia muscular de Duchenne / Maria Clara Drummond Soares de Moura; orientador Luiz Eduardo Ribeiro do Valle. -- São Paulo, 2009.

$103 \mathrm{p}$.

Dissertação (Mestrado - Programa de Pós-Graduação em Psicologia. Área de Concentração: Neurociências e Comportamento) Instituto de Psicologia da Universidade de São Paulo.

1. Distrofia muscular 2. Atenção 3. Cognição I. Título.

RC935.M7 


\section{FOLHA DE APROVAÇÃO}

Maria Clara Drummond Soares de Moura

Alterações atencionais na Distrofia Muscular de Duchenne

Dissertação apresentada ao Instituto de Psicologia da Universidade de São Paulo para obtenção do título de mestre em Neurociência e Comportamento.

Área de concentração: Neurociências e Comportamento

Aprovado em:

Banca Examinadora

Prof. Dr.

Instituição: Assinatura

Prof. Dr.

Instituição: Assinatura

Prof. Dr.

Instituição: Assinatura 


\section{DEDICATÓRIA}

A todos os pacientes com Duchenne, que espero que se beneficiem com este trabalho. 


\section{AGRADECIMENTOS}

Ao Prof. Ribeiro, pela orientação, dedicação, paciência e entusiasmo. Pela oportunidade, liberdade e confiança depositadas. Por ser um exemplo pra mim.

Aos meus pais, Madalena e Paulo Cezar, que hoje podem ver os frutos de todo esforço depositados na minha formação. Pelo enorme amor e carinho. Obrigada, do fundo do meu coração.

Ao Mau, pela infinita paciência e apoio incondicional a esse meu projeto e todos os outros. Por me ajudar a concretizar os meus (e nossos!) sonhos. Amo você infinito.

À Dra. Bernadete, por me acolher no seu ambulatório e viabilizar esse trabalho.

À Claudirene, do Núcleo Sócio-Educacional do Jaguaré, por toda ajuda e cuidado, facilitando imensamente a realização desta pesquisa.

À Profa. Renata, pela confiança, carinho e apoio.

À Dra. Ginalda, à Sara e à Paula, pelas as inúmeras trocas de plantão. Sem elas o mestrado nunca teria sido possível.

À Prof. ${ }^{a}$ Yeda, Prof. ${ }^{\text {a }}$ Maria Lúcia e aos participantes do projeto piloto com idosos, na Faculdade de Saúde Pública. Foi um enorme prazer ter feito esse trabalho. Muito obrigado pela participação de todos.

Ao Prof. Marcelo, por seu papel determinante na escolha da minha linha de pesquisa. E pelas contribuições essenciais durante a qualificação.

Ao Prof. Vinícius por toda ajuda desde as primeiras idéias deste projeto.

A todos os meninos que participaram deste trabalho, que toparam fazer os testes, mesmo não sendo exatamente um “joguinho de videogame super legal”...

À Abdim e aos meus antigos pacientes, que me deram a oportunidade de amar a Distrofia Muscular. 
A todas as meninas do laboratório, pela ajuda imprescindível, pelo carinho e amizade, me dando o enorme prazer de estar, sempre que possível, dividindo os momentos deliciosos na nossa salinha!

À Marina, amiga querida de todas as horas, incluindo a participação em cada passo deste projeto.

A todos da minha querida família, que mesmo à distância, sei que torcem por mim.

Enfim, a todos aqueles que de alguma forma fizeram parte desta conquista. 


\section{RESUMO}

Moura, M.C.D.S. Alterações atencionais na Distrofia Muscular de Duchenne. 2009. 103 folhas. Dissertação (mestrado). Instituto de Psicologia, Universidade de São Paulo, São Paulo, 2009.

A Distrofia Muscular de Duchenne (DMD) é uma doença de herança genética recessiva que gera um quadro de fraqueza muscular progressiva muitas vezes associada à deficiência mental. A atenção, considerada como o mecanismo cerebral que permite o processamento de uma informação em detrimento de outras, poderia estar alterada na doença contribuindo pelo menos em parte para o comprometimento cognitivo global observado. OBJETIVO: Investigou-se o desempenho atencional de meninos portadores de DMD utilizando-se testes psicofísicos específicos. MÉTODOS: Testou-se 30 meninos com DMD (GD) e 30 meninos saudáveis (GC), com idade entre 10 e 16 anos, em uma tarefa de tempo de reação de escolha, que consistia em responder o mais rapidamente possível a um estímulo alvo visual lateralizado com mão do mesmo lado. Antes do aparecimento deste estímulo, orientava-se a atenção automática do participante por meio de um estímulo visual periférico não-informativo espacialmente ou então sua atenção voluntária, por meio de um estímulo visual central que informava o local de maior probabilidade de aparecimento do estímulo alvo. RESULTADOS: Os tempos de reação (TR) foram maiores para o GD do que para o GC tanto no teste de atenção automática $(\mathrm{p}<0,001)$ quanto no teste de atenção voluntária $(p<0,001)$. Os TR no teste de atenção voluntária foram menores do que no teste de atenção automática no caso do GD ( $\mathrm{p}<0,001)$ mas não no caso do $\mathrm{GC}(\mathrm{p}=0,20)$. O efeito atencional (diferença entre o TR na condição oposta/inválida e o TR na condição mesma/válida) não diferiu entre os dois grupos no caso da atenção automática $(p=0,846)$, mas foi maior no GD do que no GC no caso da atenção voluntária $(\mathrm{p}<0,001)$. Não foram observadas quaisquer assimetrias interlaterais. DISCUSSÃO: Os resultados sugerem que os meninos com DMD apresentam prejuízo na capacidade de orientar a atenção no tempo e também gerenciam de modo anômalo para a idade a atenção espacial voluntária. O grande efeito atencional apresentado por eles é compatível com um atraso na maturação do seu sistema atencional.

Palavras-chave: Distrofia Muscular de Duchenne, atenção, cognição 


\begin{abstract}
Moura, M.C.D.S. Attentional disturbance in Duchenne Muscular Dystrophy. 2009. 103 folhas. Thesis (Master). Instituto de Psicologia, Universidade de São Paulo, São Paulo, 2009.
\end{abstract}

OBJECTIVE: Considering the divergence in the literature regarding the base of the cognitive deficits in Duchenne Muscular Dystrophy (DMD) patients, the objective of this work was to investigate their attention performance using psychophysical tests.

METHODS: 25 boys with DMD (GD) and 25 healthy boys (GC), which were 10 to 16 years old, were tested in a choice reaction time task. They were instructed to respond as fast as possible to a lateralized visual target stimulus with the same side hand. Attention was automatically oriented by a peripheral spatially non-informative prime stimulus or, alternatively, voluntarily oriented by a central spatially informative cue.

RESULTS: Reaction times (RT) were higher for GD than for GC in both automatic attention $(\mathrm{p}<0,001)$ and voluntary attention tests $(\mathrm{p}<0,001)$, as expected. RTs in voluntary attention tests were smaller than on automatic attention tests for GD $(p<0,001)$ but not for GC $(p=0,200)$. The attentional effect (difference between RT in the opposite/invalid condition and RT in the same/valid condition) was found not to differ between the two groups in the case of automatic attention ( $\mathrm{p}=0,846)$; however it was greater for GD than for $\mathrm{GC}$ in the case of voluntary attention $(\mathrm{p}<0,001)$. Interlateral asymmetries have not been observed.

CONCLUSION: These results suggest that patients with DMD are less efficient to allocate both automatic and voluntary attention. The lack of the expected motor preparation by the patients when the peripheral prime stimulus was used suggests a disturbance of temporal attention. The larger cost and benefit observed when the endogenous visual cue was used suggests a delay in maturation of the executive functions necessary to adequately allocate voluntary attention.

Keywords: Muscular Dystrophy, Duchenne, attention, cognition 


\section{LISTA DE FIGURAS}

Figura 1. Evolução clínica da Distrofia Muscular de Duchenne...........................

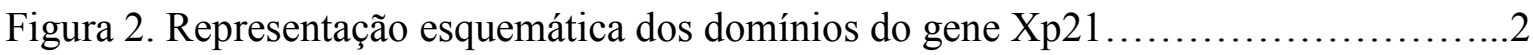

Figura 3. Representação esquemática do genoma do gene Xp21, proteínas codificadas e suas localizações ..................................................................

Figura 4. Representação do western-blot da distrofina e suas isoformas em cérebro normal,

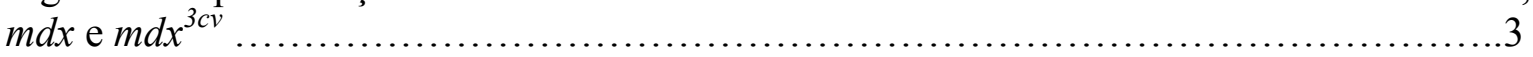

Figura 5. Representação esquemática da sequência de apresentações visuais no teste de

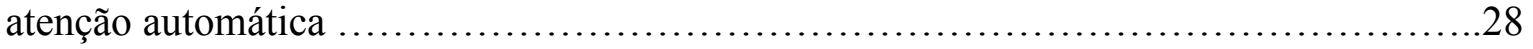

Figura 6. Representação esquemática da sequência de apresentações visuais no teste de

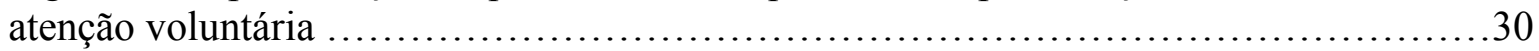

Figura 7. Média (土e.p.m) dos tempos de reação, dos grupos Controle e Duchenne, nas condições mesma, neutra e oposta no teste de atenção automática; e condições válida, neutra e inválida no teste de atenção voluntária .36

Figura 8. Média ( \pm e.p.m) dos efeitos de benefício e custo em milissegundos da pista sobre o alvo para os grupos Controle e Duchenne nos testes de atenção automática e de atenção voluntária

Figura 9. Número total de erros de inversão nas condições válida, neutra e inválida dos grupos Controle e Duchenne no teste de atenção voluntária

Figura 10. Correlação entre o efeito atencional automático e a idade para os meninos com DMD.

Figura 11. Correlação entre o efeito atencional voluntário e a idade para os meninos com DMD. 


\section{LISTA DE TABELAS}

Tabela 1. Localização dos promotores e isoformas da distrofina no Sistema Nervoso

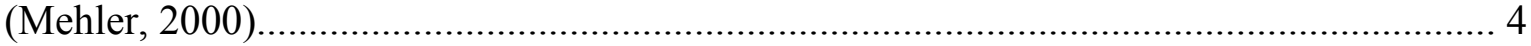

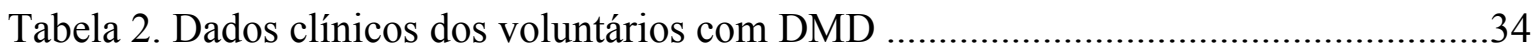

Tabela 3. Médias ( \pm e.p.m) em milissegundos dos tempos de reação de cada grupo nas três condições nos teste de atenção automática e atenção voluntária .........................................36

Tabela 4. Médias ( \pm e.p.m) em milissegundos dos efeitos de benefício e de custo de cada grupo nos testes de atenção automática e atenção voluntária.

Tabela 5. Tabela de leitura pra perto. Teste de acuidade visual. .79

Tabela 6. Tempos de reação no teste de atenção automática para o Grupo controle (GC) e Grupo Duchenne (GD)....

Tabela 6.2. Tempos de reação no teste de atenção voluntária para o Grupo controle (GC) e Grupo Duchenne (GD).....

Tabela 6.3. Efeitos atenção automática (benefício, custo e efeito atencional total) para o Grupo controle (GC) e Grupo Duchenne (GD)

Tabela 6.4. Efeitos atenção voluntária (benefício, custo e efeito atencional total) para o Grupo controle (GC) e Grupo Duchenne (GD).

Tabela 6.5. Erros de antecipação nos testes de atenção automática e atenção voluntária para o Grupo controle (GC) e Grupo Duchenne (GD)....

Tabela 6.6. Erros de omissão nos testes de atenção automática e atenção voluntária para o Grupo controle (GC) e Grupo Duchenne (GD).

Tabela 6.7. Erros de inversão no teste de atenção automática para o Grupo controle (GC) e Grupo Duchenne (GD).... 90

Tabela 6.8. Erros de inversão no teste de atenção voluntária para o Grupo controle (GC) e Grupo Duchenne (GD)

Tabela 6.9. Idades e efeito atencional no teste de atenção voluntária para o Grupo Duchenne (GD) 
Of.0102/CEPH-01.02.07

Senhor Professor,

O Comitê de Ética em Pesquisa com Seres Humanos do IPUSP (CEPH-IP), em reunião de 04/12/2006, aprovou o projeto intitulado "Desempenho atencional em pacientes portadores de Distrofia Muscular de Duchenne: uma avaliação comportamental" a ser desenvolvido pela mestranda Maria Clara Drummond Soares de Moura, sob a orientação de V.Sa., na área de concentração Neurociências e Comportamento, no Instituto de Ciências Biomédicas da Universidade de São Paulo.

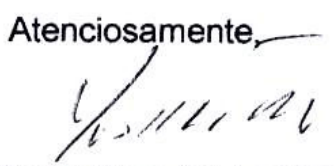

Prof. Titular Yves De La Taille CEPH-IP

IImo. Sr.

Prof. Dr. Luiz Eduardo Ribeiro do Valle

Departamento de Fisiologia e Biofísica

Instituto de Ciências Biomédicas da Universidade de São Paulo

Av. Prof. Mello Moraes, 1721 - Cidade Universitária - 05508-020 - São Paulo - SP - Brasil Fone: (11) 3031.2965 - Fax: (11) 3097.0529 - www.ip.usp.br 


\section{APROVAÇÃO}

A Comissão de Ética para Análise de Projetos de Pesquisa - CAPPesq da Diretoria Clínica do Hospital das Clínicas e da Faculdade de Medicina da Universidade de São Paulo, em sessão de 20.06.07, APROVOU o Protocolo de Pesquisa $n^{\circ}$ 0130/07, intitulado: "DESEMPENHO ATENCIONAL EM PACIENTES COM DISTROFIA MESCULAR DE DUCHENNE: UMA AVALIAÇĀO COMPORTAMENTAL", apresentado pelo DEPARTAMENTO DE NEUROLOGIA, inclusive O Termo de Consentimento Livre e Esclarecido.

Cabe ao pesquisador elaborar e apresentar à CAPPesq, os relatórios parciais e final sobre a pesquisa (Resolução do Conselho Nacional de Saúde n 196, de 10.10.1996, inciso IX. 2, letra "C")

Pesquisador (a) Responsável: Prof ${ }^{a}$. Dr. ${ }^{a}$ Umbertina Conti Reed Pesquisador (a) Executante: Maria Clara Drummond Soares de Moura

CAPPesq, 20 de junho de 2007.

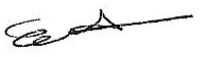

PROF. DR. EDUARDO MASSAD

Presidente da Comissão de Ética para Análise de Projetos de Pesquisa

Comissāo de Ética para Análise de Projetos de Pesquisa do HCFMUSP e da FMUSP 作 Ovídio Pires de Campos. 225. 5 andar - CEP 05403 ol - são Pariacappesq2@hcnet.usp.br Fone: 011 - 30696442 fax: 011 - $30696492-e-m a i l$ : $\frac{\text { capp }}{\text { sol }}$ 


\section{SUMÁRIO}

1. INTRODUÇÃO 1

1.1 Bases neurais do comprometimento cognitivo na Distrofia Muscular de Duchenne. 4

1.2 Alterações cognitivas evidenciadas na Distrofia Muscular de Duchenne. 10

1.3 Atenção na Distrofia Muscular de Duchenne. 14

1.4 Avaliação quantitativa da atenção.

2. OBJETIVOS 23

2.1 Objetivo geral 23

2.2 Obejetivos específicos 23

3. MÉTODOS 24

3.1 Participantes 24

$\begin{array}{ll}3.2 \text { Materiais } & 26\end{array}$

3.3 Procedimentos $\quad 26$

3.4 Análise Estatística 31

4. RESULTADOS 33

4.1 Tempos de Reação

4.2 Benefício e Custo $\quad 37$

4.3 Acurácia 40

4.4 Correlação entre a idade e o efeito atencional nos meninos com DMD. 41

5. DISCUSSÃO 44

5.1 Atenção Automática $\quad 44$

5.2 Atenção Voluntária $\quad 49$

5.3 Possíveis bases neurais das alterações atencionais observadas 55

5.4 Alterações atencionais e suas implicações na vida diária dos portadores de DMD. 58

6. CONCLUSÃO 63

7. REFERÊNCIAS BIBLIOGRÁFICAS 64

8. ANEXOS 78

$\begin{array}{ll}\text { Anexo } 1 \text { - Inventário de Edinburgh } & 78\end{array}$

$\begin{array}{ll}\text { Anexo } 2 \text { - Teste de acuidade visual } & 79\end{array}$

Anexo 3 - Termo de Consentimento Livre e Esclarecido $\quad 80$

Anexo 4 - Descrição do teste de atenção automática $\quad 82$

Anexo 5 - Descrição do teste de atenção voluntária $\quad 83$

Anexo 6 - Tabelas de Dados $\quad 84$ 


\section{INTRODUÇÃO}

A Distrofia Muscular de Duchenne (DMD) é uma doença de herança genética recessiva que apresenta a segunda maior incidência entre todas as doenças hereditárias, apresentando um afetado para cada 3.300 nascimentos do sexo masculino (Emery, 1991). A doença se manifesta em meninos primariamente como um prejuízo na marcha por volta dos 3-5 anos, seguida da necessidade de uso de cadeira de rodas por volta dos 10 a 12 anos e morte por insuficiência cardio-respiratória entre a segunda e terceira décadas de vida. A evolução motora da doença se deve a uma fraqueza muscular progressiva, irreversível, devido à perda da musculatura esquelética como conseqüência da deficiência de uma proteína denominada distrofina (Anderson et al., 2002; Bach, 2004).

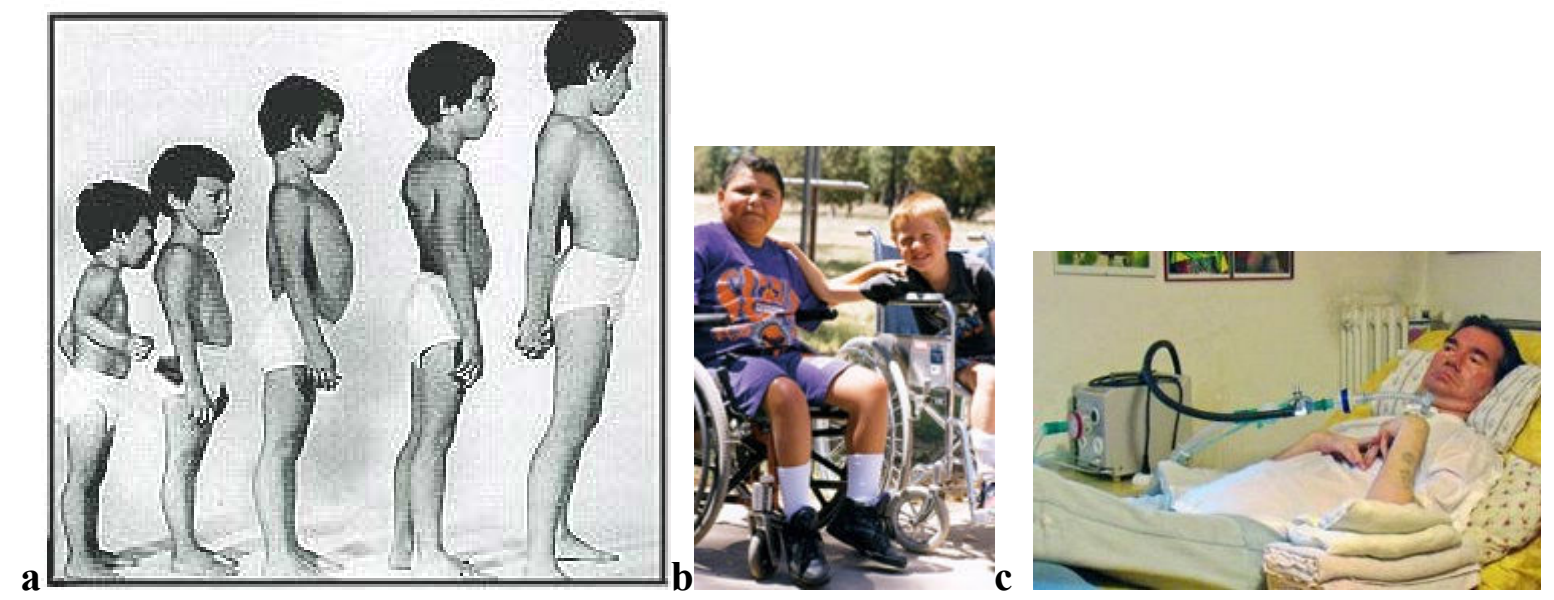

Figura 1: a) Alterações posturais decorrentes da progressiva perda de força muscular em meninos com DMD, levando à perda da marcha (b) e necessidade de assistência ventilatória (c), culminando com a morte na $2^{\mathrm{a}}$ ou $3^{\mathrm{a}}$ décadas de vida (c).

Esta proteína é o produto do gene Xp21 (ou $D M D$ ), gene extremamente longo, com numerosos exons e extensiva região de decodificação, localizado no braço curto do cromossomo X (Mehler, 2000). A DMD é causada por deleções neste gene em 60-70\% dos pacientes, por duplicações em $5-10 \%$ e por mutações pontuais ou pequenos rearranjos em 20-30\% dos casos, sendo em média dois terços casos esporádicos e apenas $1 / 3$ dos casos por origem familiar, hereditária (Moizard et al, 1998; Felisari et al, 2000). 
Apesar de o comprometimento muscular ser o primeiro sintoma e a principal causa de mortalidade nos pacientes com DMD, outros órgãos também estão envolvidos na doença, incluindo o Sistema Nervoso Central (Yaffe et al,1992).

O gene Xp21 é transcrito por três promotores que produzem a proteína distrofina completa (Dp427). O promotor-M está ativo na musculatura esquelética e cardíaca que, na sua ausência, caracteriza a perda muscular irreversível e progressiva. Também está ativo dentro do Sistema Nervoso Central (SNC), sintetizando a distrofina nas células da glia e células endoteliais fetais. Além deste, outros dois promotores (B e P) transcrevem o gene e dirigem a síntese de proteínas dentro do SNC, sendo o promotor-B nos neurônios do hipocampo e do córtex cerebral, e o promotor-P nas células de Purkinje cerebelares e também corticais fetais (Blake e Kroger, 2000; Mehler, 2000; Culligan e Ohlendieck, 2002).

A distrofina completa (Dp427) pode ser dividida em quatro domínios distintos (Figura 2), sendo que no SNC três outras proteínas menores são codificadas na porção distal no gene (C-terminal), as isoformas Dp116, Dp140 e Dp71 (veja a tabela 1). Dentre estas, as duas últimas têm maior expressão no SNC (Figura 3 e 4) (Culligan e Ohlendieck, 2002, Florencia et al, 2004).

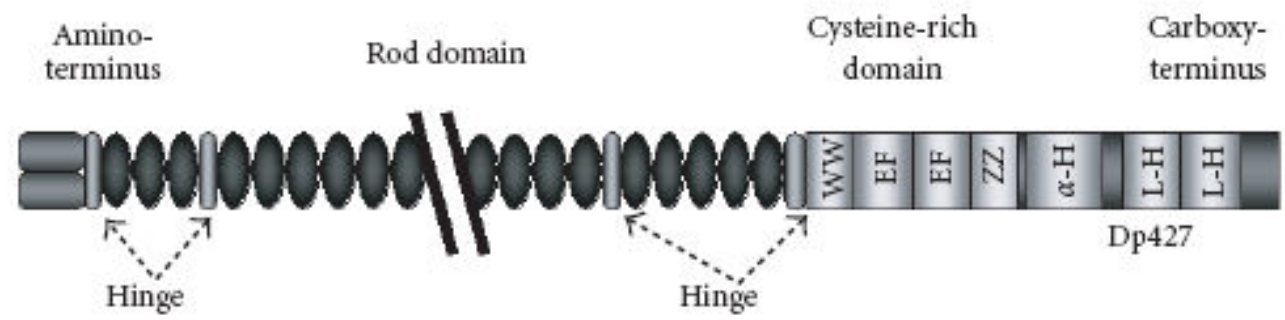

Figura 2: Os quatro domínios do gene Xp21, com ênfase à porção mais distal (C-terminal), local de codificação das isoformas truncadas mais importantes expressas nos cérebro (Culligan e Ohlendieck, 2002) 


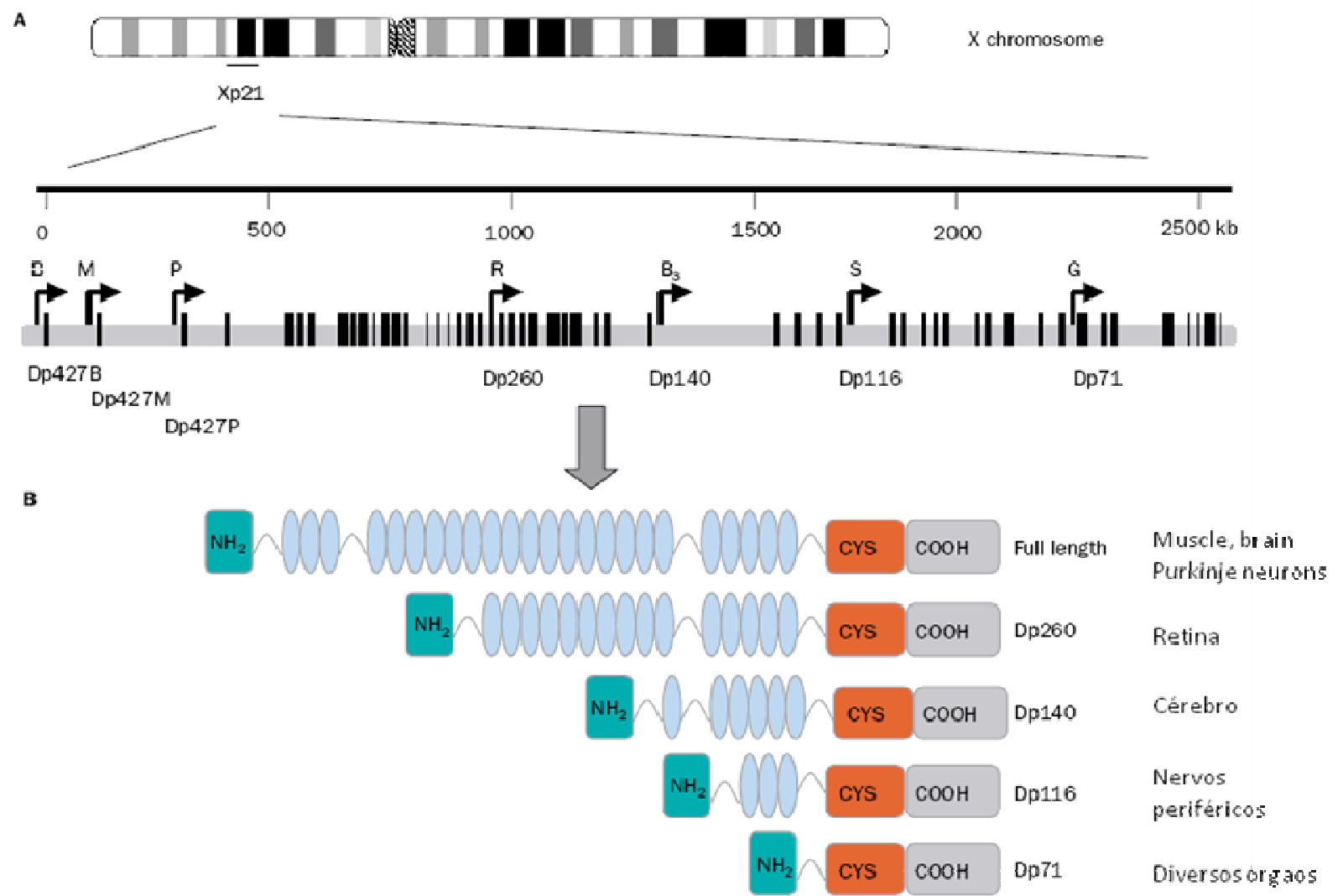

Figura 3: A) Organização no genoma do gene $\mathrm{Xp} 21$; as barras pretas representam os 79 exons e as setas os vários promotores responsáveis pela codificação das proteínas descritas logo abaixo. B) Representação das proteínas e suas localizações (Adaptado de Muntoni, Torelli e Ferlini, 2003)

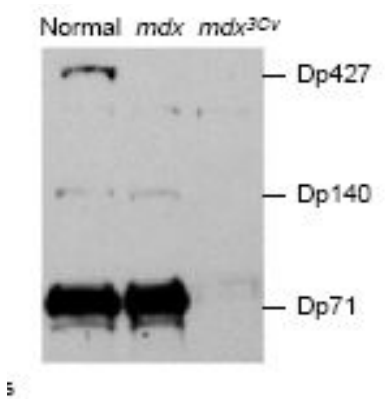

Figura 4: Western-blot da distrofina e suas isoformas no cérebro. No rato normal, a distrofina completa (Dp427) e as isoformas Dp140 e Dp71 estão presentes. No rato distrofina-deficiente $m d x$, há uma ausência específica da distrofina completa, enquanto a Dp140 e Dp71 não são afetas pela mutação. Por fim, nos cérebros dos ratos $m d x^{3 C v}$, há uma severa redução dos níveis de distrofina e todas as isoformas do $\mathrm{C}$ - terminal, não sendo detectadas nem a distrofina completa nem as isoformas menores (Blake and Kröger, 2000). 
Tabela 1: Localização dos promotores e isoformas da distrofina no Sistema Nervoso (Mehler, 2000).

1. C: Codes for full-length tramscripts present in cerebral cortical and hippocampal (CA region) neuroms; subcellular localization: neuronal somadendritic microdomains.

2. M: Codes for full-length transcripts present in CNS glia and vascular endothelial cells.

3. P: Codes for fill-length transcripts present in cerebellar Purkinje cells and fetal cerebral cortex.

4. Dp260: Truncated transcripts spliced in-frame to exan 30; present at synapse between retinal photoreceptor cells and ON bipolar cells.

5. Dpl40: Truncated transcripts spliced in-frame to exan 45; present in astrocytes in the neuropil during development, an leptomeningeal surfaces and along penetrating blood vessels, ensheathing the olfactory nerve and in the neurohypohysis.

6. S (Dpl 16): Truncated tramscripts spliced in-frame to exon 57; present in late human fetal and neonatal diencephalon (caudate/putamen) and in peripheral nerves.

7. G (Dp71): Truncated transcripts spliced in-frame to exon 64; present in embryonic stem cells, ventral neural tube, embryonic midbrain and hindlurain, perinatal brain correlated with stages of terminal neural differentiation, and in forrebrain with persistence in adult life predominantly in the cerebral cortex, gramule neurons of the hippocanpal dentate gyrus, olfactory bulb, pituitary, retina, and neocortical regions associated with angoing neurogemesis and synaptic plasticity; subcellnlar localization: associated with synaptic vesicles, microsomes and mitochandria.

\subsection{Bases neurais do comprometimento cognitivo na Distrofia Muscular de}

\section{Duchenne.}

A idéia de que as funções cognitivas, além da função motora, também estariam alteradas nos pacientes com DMD foi primeiramente considerada por Duchenne de Boulogne, na segunda metade do século 19 (Duchenne, G. 1868). Mas foi somente após mais de um século depois, a partir de 1980, que os pesquisadores buscaram detalhar mais profundamente os déficits mentais e elucidar seu substrato anatômico.

Em geral, em encéfalos normais, a Dp427 (proteína distrofina completa) e suas isoformas estão mais concentradas na densidade pós-sináptica (DPS) de neurônios piramidais do neocórtex cerebral (principalmente camadas profundas das células piramidais do córtex frontal), regiões hipocampais e, de forma mais abundante, no soma e nos dendritos de células de Purkinje no cerebelo (Lidov et al, 2000, Lidov, Byers e Kunkel, 1993). Foi verificado, porém, que a proteína não é expressa nem em encéfalos de ratos $m d x$ (muscular dystrophy X-linked, modelo de rato com deficiência de distrofina) (Anderson et al., 2002, Mehler, 2000) nem no cortex cerebral de menino com DMD (após autópsia comparativa com cérebro controle) (Kim et al., 1995). Isto sugere que a atividade sináptica seja claramente distinta entre os sujeitos normais, com densidade normal da proteína no SNC, e aqueles com deficiência de distrofina. 
A etiologia precisa do comprometimento mental nos meninos com DMD ainda permanece pouco clara, mas os trabalhos têm evidenciado sua correlação com alterações genéticas específicas (al-Qudah et al., 1990; Rapaport et al., 1991; Moizard et al., 1998 e 2000; Bardoni et al., 2000; Felisari et al., 2000). Muitos trabalhos descrevem que o atraso no desenvolvimento neuropsicomotor e a deficiência mental estão preferencialmente associados a alterações genéticas afetando o terço final do gene Xp21, justamente o local de codificação para as proteínas truncadas (Rapaport et al, 1991; Hodgson et al, 1992; Bushby et al, 1992 e 1995, Giliberto et al, 2004).

Florencia e colaboradores (2004) observaram que deleções em diferentes regiões do gene Xp21 podem afetar a expressão de uma ou várias isoformas da distrofina, levando a déficits multifuncionais de nível moderado a grave. A ausência das três isoformas truncadas (Dp71, Dp140 e Dp116), resultado de deleções na porção distal do gene, pode gerar efeitos cumulativos, levando à deficiência mental severa. Pacientes com deleções proximais raramente apresentam um severo grau de comprometimento mental. Nestes casos, com a deficiência apenas da distrofina completa (Dp427), mantendo a transcrição das demais isoformas menores da distrofina, as funções cognitivas parecem estar comprometida apenas de forma leve ou moderada (Moizard et al, 1998; Giliberto et al, 2004) ou até mesmo não serem afetadas (den Dunnen et al, 1991; Hodgson et al, 1992; Nicholson et al, 1993).

Apesar do papel da distrofina completa (Dp427) no SNC ainda ser pouco clara, evidências sugerem que ela aja no direcionamento (targeting) ou na estabilização dos receptores GABAa na densidade pós-sináptica da membrana celular sendo que, na sua ausência, há diminuição no tamanho e número de agrupamentos destes receptores nas sinapses do SNC de ratos $m d x$ (Knuesel et al., 1999; Kueh, Head and Morley, 2008). 
Conseqüências disto são os distúrbios na plasticidade sináptica evidenciados nos ratos $m d x$. Foi observada uma diminuição significativa na depressão de longo prazo (LTD) nas células de Purkinje cerebelares destes animais, gerada possivelmente por um distúrbio na homeostase do cálcio (Anderson, Head and Morley, 2004). Já no hipocampo, a deficiência de distrofina gera um aumento na potenciação de curto e de longo prazo (STP e LTP, respectivamente), além de uma melhora na eficiência sináptica e na excitabilidade neural dos neurônios da região CA1 hipocampal. Isto se daria provavelmente por uma lentificação no disparo de receptores NMDA causada pelo número reduzido de receptores GABAa (Vaillend e Billard, 2002; Vaillend, Billard and Laroche, 2004). Estas alterações foram encontradas em animais que apresentaram também importante distúrbio na consolidação e expressão na memória de reconhecimento de longo-prazo, sugerindo que um aumento anormal da plasticidade sináptica e da excitabilidade neural podem ser deletérias para as funções cognitivas, visto que alterações similares foram também observadas em pacientes com Doença de Alzheimer (Jolas et al, 2002). Assim, sugere-se que a ausência da Dp427 poderia interferir de modo importante na função neural e, conseqüentemente cognitiva, também de meninos com DMD (para revisão, veja Poysky, 2007).

Já a função das isoformas truncadas da distrofina ainda permanece desconhecida, porém sabe-se que a sua ausência é ainda mais relevante para a função cognitiva de meninos com DMD. Em trabalho realizado no Brasil, 50\% dos 148 pacientes com DMD avaliados apresentaram deficiência mental, sendo que o exon 52 se mostrou funcionalmente determinante para a manifestação deste comprometimento. Setenta por cento dos pacientes com mutação neste exon apresentaram a deficiência, e, ao contrário, $62 \%$ de todos os pacientes com o déficit apresentaram este tipo de deleção (Rapaport et al., 1991). Trabalhos posteriores encontraram incidência um pouco inferior da mesma 
correlação genética (Nicholson et al. 1993, Bushby et al, 1995). No caso, a deleção no exon 52 parece interromper a seqüência de codificação de uma das isoformas da distrofina expressas no cérebro que tem espacial correlação com o comprometimento cognitivo nos pacientes com DMD, a Dp140 (Moizard et al, 1998; Bardoni et al, 2000).

A Dp140 tem sua transdução iniciada no exon 51, sendo expressa principalmente nos tecidos fetais e em pequena quantidade no adulto (Lidov, Selig e Kunkel, 1995; Morris, Simmons \& Nguyen 1995). Ela está distribuída pela superfície cerebral leptomeningeal e ao longo dos vasos perfurantes, o que favorece a idéia de seu papel do déficit cognitivo na DMD (Moizard et al, 1998). Devido à sua maior presença durante a embriogênese, acredita-se que a ausência da Dp140 poderia ser um dos elementos genéticos a influenciar a maturação harmoniosa do Sistema Nervoso Central (Felisari et al. 2000). Em casos de DMD em que não há expressão da Dp140 o comprometimento intelectual é maior do que nos casos em que a proteína está presente; e ainda, em pacientes em que a inteligência é normal, a Dp140 está sempre presente (Bardoni et al, 2000; Felisari et al. 2000).

Outra isoforma, a de maior impacto no encéfalo, é a Dp71. Ela é encontrada também na retina, no fígado e nos rins. No SNC está presente no córtex cerebral, cerebelo, no plexo coróide ventricular, e hipocampo (Lumeng et al, 1999, Mehler, 2000), num aumento de concentração crescente da proteína desde a fase embrionária até a fase adulta (Jung et al, 1993, Morris, Simmons \& Nguyen, 1995). Seu papel ainda não é bem conhecido, mas além de sua ação direta, a proteína é também responsável pela codificação de outras proteínas, complicando ainda mais o entendimento de seu papel nas funções cerebrais e no desenvolvimento do SNC (Austin et al, 2000). Esta isoforma da distrofina está associada intimamente à membrana plasmática sináptica, sugerindo possível envolvimento com a transmissão de impulsos nervosos (Moizard et al., 1998). Marquez e 
colaboradores (2003) sugerem que a Dp71 tenha participação durante a fase de diferenciação celular de células prototípicas em células neuronais na presença de fator de crescimento neuronal (Marquez et al, 2003). O aumento gradual e precoce dos níveis de Dp71 no cérebro anterior embrionário normal persistindo até a vida adulta sugere um papel da proteína no desenvolvimento do $\mathrm{SNC}$, favorecendo o comprometimento que a sua ausência gera na inteligência de meninos com DMD. Os quadros mais graves de deficiência mental na DMD estão descritos na ausência da Dp71. A prematura terminação da transcrição na seqüência de codificação da Dp71 está preferencialmente relacionada a um retardo mental severo (Moizard et al., 2000).

Além das isoformas Dp140 e Dp71, a Dp 260 tem um papel importante no componente visual pela sua presença nas células fotorreceptoras da retina. É bem descrita na literatura alterações neurofisiológicas na retina de meninos com DMD, avaliadas através da eletroretinografia e potencial relacionado ao evento (Girlanda et al, 1997; Pascual Pascual et al, 1998), porém as alterações oftalmológicas já são mais controversas. Trabalho recente verificou que os meninos com DMD apresentam defeito na visão de cores para verde-vermelho, e que a alteração está intimamente relacionada à ausência da Dp 260 (Costa et al, 2007); porém outras funções visuais como a acuidade visual e motilidade ocular parecem estar preservadas (Sigesmund et al, 1994).

Outras evidências obtidas em estudos neuropatológicos parecem contribuir para a idéia de um substrato anatômico para o comprometimento cognitivo apresentado na DMD. Através de estimulação magnética transcraniana, Yayla et al (2008) não observaram alterações eletrofisiológicas relacionadas à doença, enquanto Di Lazzaro (1998) obteve resposta diminuída da excitabilidade do córtex motor, que o autor relaciona à falta de distrofina cortical, e não à alteração do trato cortico-espinhal em si. Por meio de tomografia computadorizada (TC) 30 casos de DMD foram avaliados e verificou-se atrofia 
cerebral leve em $67 \%$ dos pacientes, dilatação ventricular leve em $60 \%$ e atrofia cortical em $30 \%$. A avaliação cognitiva destes pacientes demonstrou que 1/3 deles apresentou deficiência mental, e destes, a maioria apresentava alterações na TC. Porém, mesmo aqueles que apresentaram TC normal, também apresentaram graus variados de comprometimento cognitivo (Yoshioka et al., 1980). Por outro lado, Dubowitz e Crome (1969), em necropsia com 21 meninos portadores de DMD não observaram nenhuma alteração estrutural no encéfalo.

Exames de tomografia por emissão de pósitrons (PET) foram mais conclusivos quanto ao funcionamento do encéfalo dos pacientes com DMD, permitindo uma maior compreensão das áreas acometidas nos pacientes. Bresolin et al. (1994) relatam presença de hipometabolismo cerebelar bilateral em todos os pacientes com DMD examinados. Estes pacientes apresentaram ainda variável envolvimento de áreas corticais associativas. Já trabalho mais recente, verificou alterações mais claras na área sensório-motora, no neocortex temporal, em estruturas temporais mediais e no cerebelo. Estas áreas são justamente aquelas ricas em distrofina, o que fortalece a idéia de que na sua ausência a função sináptica estaria alterada. Os autores também encontraram déficits cognitivos e comportamentais nos pacientes não havendo, no entanto, correlação entre os dois achados (Lee et al., 2002).

Em estudo utilizando imageamento por ressonância magnética (iRM) foi identificado um aumento na taxa de fosfato inorgânico/ATP em pacientes com DMD, que apresentou correlação positiva com o déficit cognitivo apresentado por eles (Tracey et al, 1995). Alterações também foram observadas com relação a compostos contendo colina. Kato et al. (1997) relatam a presença destes compostos no córtex frontal de pacientes mais velhos que 17 anos. Por outro lado Rae et al. (1998) encontraram elevação na taxa desses compostos apenas no cerebelo esquerdo, não os evidenciando no lobo frontal em pacientes 
com menos de 13 anos. Estes autores não encontraram associação significativa entre os níveis de colina no cerebelo e os resultados dos testes de inteligência, questionando a correlação direta entre as alterações bioenergéticas e o déficit cognitivo característicos da DMD (Rae et al. 1998).

\subsection{Alterações cognitivas evidenciadas na Distrofia Muscular de Duchenne.}

Para examinar mais detalhadamente as alterações cognitivas na DMD, diversos trabalhos têm usado testes neuropsicológicos para acessar tanto a inteligência como um todo (Coeficiente de inteligência, ou QI), como também os déficits específicos em cada função mental. Um estudo de meta-análise determinou as médias de testes simples de QI para pacientes com DMD, considerando QI total (QIT), QI verbal (QIV) e QI de performance (QIP, não-verbal). Considerando os 1146 meninos com DMD entre os trabalhos relacionados (média de 12,26 \pm 4,06 anos), a média do QIT foi de 80.2 , do QIV médio de 80.4, e do QIP de 85.4, sendo todos estatisticamente menores do que a média da população normal, que é 100 para os três casos. Os dados corroboram com a idéia de que os componentes que envolvem a linguagem são no geral mais prejudicados nos pacientes com DMD do que aqueles que envolvem de execução (Cotton, Voudouris e Greenwood, 2001).

Já foi bem estabelecido na literatura que aproximadamente $30 \%$ dos indivíduos apresentam deficiência mental (DM), determinado pelo QI abaixo de 70 (Yoshioka, 1980; Bushby, 1992; Nicholson et al., 1993; Bardoni et al., 2000; Blake e Kröger, 2000), sendo esta uma incidência muito maior do que a observada na população normal (aproximadamente 2\%) (Poysky, 2007). Na meta-análise citada anteriormente, do total de 1146 pacientes, 34,8\% apresentaram DM. Destes, 79,3\% apresentaram DM leve (QI entre 50 e 70$) ; 19,3 \%$ apresentaram DM moderada (QI entre 35 e 50); 1,1\% com DM severa (QI 
entre 20 e 35); e 0,3\% com retardo mental profundo (QI menor que 20) (Cotton, Voudouris e Greenwood, 2001). Mas é importante notar que há um continuum nas habilidades intelectuais dos pacientes, com escores evidenciando desde quadros muito comprometidos $(\leq 70)$ até superiores aos de meninos saudáveis (escores $\geq 130$ ), sendo que a maioria dos pacientes se encontra dentro dos limites normais de inteligência. E dentre os testes avaliados, os índices que mostraram maior comprometimento foram aqueles envolvendo vocabulário, aritmética e memória (Digit Span) (Poysky, 2007).

Na mesma linha, outros trabalhos têm tentado caracterizar mais precisamente os déficits cognitivos que estariam levando ao prejuízo da inteligência dos pacientes demonstrado pelos testes de QI. Testes mais específicos têm sido aplicados, como os comportamentais em ratos $\mathrm{mdx}$ e os neuropsicológicos em crianças. E a memória tem sido descrita como a função cognitiva mais comprometida. Tarefas com ratos $\mathrm{mdx}$ demonstraram comprometimento do aprendizado de esquiva passiva, não relacionado à aquisição da tarefa ou à memória de procedimento, mas sim ao esquecimento rápido de novas informações aprendidas (Muntoni et al., 1991; Vaillend et al., 1995). Em trabalho mais recente, Vaillend e colaboradores (2004) observaram que a ausência de distrofina nos ratos mdx compromete a memória de reconhecimento de longo prazo, mas não a de curto prazo, e prejudica a memória espacial de longo prazo, mas não sua aquisição após treinamento massivo no labirinto na água. Assim, os autores concluem que a perda de distrofina altera a consolidação da memória tanto em tarefas de aprendizagem espacial como não espacial devido, pelo menos em parte, a alterações na plasticidade sináptica hipocampal (Vaillend, Billard and Laroche, 2004).

Já em pacientes, diversos trabalhos têm descrito o comprometimento cognitivo na DMD. Apesar de algumas funções cognitivas estarem alteradas em alguns trabalhos e não em outros, o que parece bem consistente entre todos é a presença de prejuízo em testes de 
recordação imediata de informações (Digit Span). Os autores, em geral, verificaram que haveria um déficit específico relacionado principalmente ao componente verbal da memória operacional (Whelan, 1987; Bresolin et al, 1994, Billard et al, 1998, Hinton et al. 2000, 2001, 2007). Já Wicksell e colaboradores (2004) confirmam a idéia de comprometimento maior na memória operacional, mas observaram pior desempenho dos pacientes também nos componentes visuo-espaciais da memória de curto prazo. Os autores observaram um prejuízo mais global na memória, incluindo a de longo prazo e também as funções executivas (Wicksell et al., 2004).

Para verificar o impacto do comprometimento motor e dos fatores sócio ambientais sobre os baixos resultados obtidos nos testes de QI e memória em meninos com DMD, foram realizados alguns trabalhos comparativos com Amiotrofia Espinhal Progressiva (AEP), outra doença que acomete a função motora de crianças progressivamente (Blake e Kröger, 2000). Nestes estudos, o grupo com DMD mostrou maiores deficiências para aprendizagem, apresentando os escores tanto de QI verbal como de memória significativamente menores quando comparados com o grupo AEP (Ogasawara, 1989; Billard et al., 1992 e 1998). Os trabalhos sugerem, então, que as alterações não são secundárias às limitações motoras, mas sim decorrente de características específicas da DMD.

Outro fator muito questionado quando se trata do déficit cognitivo nesses pacientes é a possibilidade de haver uma progressão do comprometimento ou alguma correlação com a idade, já que o componente motor tem a característica progressiva. Apesar de muitos autores apontarem o comprometimento como sendo estático, estudo recente evidenciou uma diminuição dos déficits após os 14 anos, concluindo que a função intelectual nos pacientes com DMD muda sim com a idade, mas não para pior. Isto não ocorre globalmente (QI total), mas sim nas funções verbais e de linguagem (QI verbal) (Cotton et 
al., 2005). No caso, crianças mais novas apresentam maiores dificuldades nos componentes de compreensão e expressão de linguagem, enquanto meninos mais velhos apresentam maiores dificuldades nos componentes de execução decorrentes dos déficits motores progressivos e das complicações médicas da idade. Outros autores também evidenciaram esta melhora tardia (Sollee et al., 1985, Bresolin et al., 1994), sugerindo inclusive que a melhora do QI em cadeirantes poderia ser explicado por mecanismos comportamentais adaptativos, como a maior maturidade para entender e lidar com a realidade da doença. Por outro lado, Yoshioka e colaboradores (1990) apesar de não evidenciarem correlação do QI com a idade ou severidade da doença, observaram alterações mais severas na TC nos meninos mais velhos.

Cotton e colaboradores (1998) discutem um fator interessante que poderia estar relacionado aos pacientes que é a possibilidade de haver uma assimetria funcional dos déficits. Os autores descrevem que haveria um comprometimento específico de memória para faces, e não para palavras, nos pacientes com DMD, relacionando a resultados encontrados em indivíduos com lesões corticais em hemisfério direito. Estes dados podem ser sustentados por uma assimetria cortical também evidenciada por hipometabolismo em áreas específicas do hemisfério direito, como o córtex temporal lateral, giro pós-central e hipocampo (Lee et al., 2002). Billard e colaboradores (1998) consideraram ainda que os déficits dos pacientes com DMD de processamento verbal e na habilidade de leitura seriam comparáveis a quadros encontrados na dislexia disfonética, o subtipo mais comum de dislexia, que tem sido relacionada à disfunção do cerebelo direito (Anderson et al., 2002) ou mesmo a uma assimetria inter-hemisférica desregulada (Wijers et al., 2005).

O cerebelo tem sido foco principal da relação entre a ausência de distrofina e os achados neuropsicológicos. Em estudo de revisão recente, Cyrulnick e Hinton (2007) defendem que os déficits cognitivos específicos dos pacientes com DMD estão 
intimamente relacionados a comprometimento funcional do cerebelo. Apesar de diversas áreas do SNC estarem envolvidas na memória operacional verbal, as autoras acreditam que circuitos cerebro-cerebelares proveriam uma suposta explicação para os déficits. Ravizza et al. (2006) fortalecem esta idéia ao descreverem que lesões cerebelares geram déficits específicos na memória operacional verbal. O cerebelo contribuiria de maneira importante para aspectos de codificação fonológica, mais do que articulatórios.

\subsection{Atenção na Distrofia Muscular de Duchenne}

A atenção é um processo cognitivo cuja definição é extremamente difícil e controversa, apresentando confusões e ambigüidades inerentes tanto ao termo como à sua função e atuação (Nahas e Xavier, 2004). Gazzaniga, Ivry e Mangun (2006) definem a atenção como um mecanismo cerebral cognitivo que permite o processamento de uma aferência, um pensamento ou uma ação, enquanto ignora outros irrelevantes ou distraidores. Ou ainda, de maneira mais simples, Arrington e colaboradores (2000) descrevem que a atenção tem o papel de selecionar uma informação a ser dada prioridade durante a percepção. Mas talvez a definição e função de atenção propostas por James (1890/1950) sejam, ainda hoje, aquelas mais aceitas e utilizadas no meio científico: "É a possessão da mente, de forma clara e nítida, de um objeto ou pensamento dentre várias possibilidades simultâneas. Sua essência está na focalização, na concentração da consciência. Implica no afastamento de algumas coisas para que se possa lidar de maneira efetiva com outras..." (p. 403-4).

O controle da atenção se dá por meio de fatores cognitivos como conhecimento, expectativa e objetivos comuns (controle descendente, designado usualmente como "de cima para baixo") e fatores que refletem a estimulação sensorial (controle ascendente, designado usualmente "de baixo para cima"). Outros fatores que afetam a atenção, como o 
novo e o inesperado, refletem a interação entre influências cognitivas e sensoriais. Desta forma, a interação dinâmica desses fatores controla onde, como e para quê se presta atenção no ambiente visual (Corbetta e Shulman, 2002).

Nahas e Xavier (2004) definiram os dois tipos de processos envolvidos na captação da atenção: os processos automáticos e os voluntários. Os processos automáticos podem ser desencadeados prontamente, de forma quase inevitável, por eventos inesperados do ambiente, mesmo quando a atenção está previamente alocada a uma outra fonte de estimulação. Admite-se que estes processos sejam velozes, e não requeiram um "controle ativo" por parte do indivíduo, podendo, por esta razão, ocorrer simultaneamente a outros processamentos com pouca interferência. Assim, estímulos inéditos, surpreendentes ou incongruentes atraem a atenção para si, não havendo esforço voluntário para o direcionamento atencional e sim uma captura gerada pelo estímulo, de onde a denominação atenção automática para o fenômeno. Gazzaniga, Ivry e Mangun (2006) caracterizam a atenção automática como sendo reflexa, de origem exógena.

Por outro lado, os processos voluntários da atenção dependem de controle intencional e são normalmente usados para tarefas mais complexas e pouco familiares, que requerem por este motivo, mais empenho para sua execução. Neste caso, o envolvimento da intenção leva a haver interferência no caso de desempenho concomitante de uma tarefa secundária. O direcionamento intencional de recursos de processamento para determinada fonte de informação, devido à sua relevância momentânea justifica a denominação de atenção voluntária (Nahas e Xavier, 2004) ou "atenção endógena" (Gazzaniga, Ivry e Mangun, 2006) para o fenômeno.

Normalmente a atenção se acompanha de movimentos dos olhos, da cabeça ou do corpo todo, caracterizando o que é chamado de comportamento exploratório. Esta forma de orientação da atenção é dita manifesta ou explícita. A orientação da atenção, sem 
movimentação dos olhos é denominada encoberta, e, embora bem menos comum, ocorre também naturalmente (Nahas e Xavier, 2004). Há autores que acreditam que há uma íntima relação entre os movimentos oculares e a atenção seletiva, denominada de "teoria pré-motora da atenção". De acordo com esta teoria, "os mecanismos responsáveis pela atenção espacial e os mecanismos involvidos na programação das sacadas oculares são basicamente os mesmos" (Sheliga, Riggio, Rizzolatti, 1994, 1995). Por outro lado, seguimos a linha que acredita que a atenção por definição é um processo encoberto por natureza, e os ajustes motores que usualmente a acompanham são apenas fenômenos complementares, que não apresentam mecanismos em comum com a atenção em si (Gazzaniga, Ivry e Mangun, 2006).

Apesar do comprometimento da memória operacional verbal ter sido descrito como a função mental de maior impacto sobre o déficit intelectual global e os distúrbios de leitura e aprendizagem apresentados pelos pacientes com DMD, alguns trabalhos têm sugerido que o teste em que os pacientes vão pior (Digit span) envolve componentes mentais diversos, não só memória operacional, como também atenção e linguagem (Sollee et al, 1985; Poysky, 2007). Alguns autores acreditam inclusive que seria um pior desempenho atencional que seria mais determinante para os déficits encontrados, mas nem todos avaliaram diretamente a atenção (Sollee et al., 1985; Billard et al., 1992, Rae et al., 1998, Cotton et al., 1998, Cyrulnik et al, 2008).

Testes neuropsicológicos específicos de avaliação da atenção foram utilizados em trabalhos com pacientes com DMD e evidenciaram um déficit atencional importante. Cotton e colaboradores (1998), utilizando o Symbol Digit Modality Test (SDMT), encontraram comprometimento da atenção nos pacientes com DMD quando comparados a meninos de idade e inteligência pareada. $O$ teste consiste em uma tarefa de substituição de símbolos por números de uma a nove, seguindo uma seqüência chave apresentada. Esta 
tarefa deve ser realizada o mais rápidamente possível durante 90 segundos, de forma oral ou escrita (Lezak, 1995). Os autores sugerem que os pacientes (com média de idade de 15,7 anos) teriam um comprometimento na habilidade de processar informações rapidamente e de sustentar a atenção (Cotton et al, 1998). Mais recentemente, por meio do sub-teste de atenção visual (tarefas de busca visual) do NEPSY: A Developmental Neuropsychological Assessment (Korkman, Kemp, Kirk, 2001), foi observado significativo comprometimento atencional tanto em crianças bem jovens (três a 6 anos de idade) (Cyrulnik et al, 2008) como em pacientes com DMD um pouco mais velhos (média de 8,3 anos de idade) (Marini et al., 2007). Por outro lado, outros trabalhos, apesar de não terem avaliado a atenção de forma específica, sugerem haver a preservação da função atencional dos pacientes, visto que conseguem manter a "concentração", com adequada capacidade de sustentarem a atenção (Billard et al, 1998; Hinton et al, 2000).

Dados interessantes também foram recentemente publicados sobre uma alta incidência de Transtorno de Déficit Atenção/ Hiperatividade (TDAH) nos meninos com DMD, mesmo que em estudos preliminares (Steele et al, 2008) ou por meio de entrevista qualitativa com os pais dos meninos (Hilton et al, 2006; Hendriksen \& Vles, 2008).

Desta forma, o comprometimento da atenção em pacientes com DMD ainda é uma possibilidade pouco investigada e que deve ser considerada. Os testes neuropsicológicos são pouco precisos em relação a minimizar os efeitos da memória operacional, componentes motores ou de linguagem. Esta questão deveria ser examinada sistematicamente considerando que um déficit atencional poderia ser um importante fator determinante do comprometimento cognitivo global, assim como sua relação intrínseca com a memória operacional, já bem estabelecida como deficiente nos meninos com DMD. Helene e Xavier (2003) defendem uma associação conceitual entre estas duas funções cognitivas, atenção e memória, pois enquanto a atenção é necessária para a seleção de 
informações do ambiente que serão armazenadas na memória, a atenção se baseia em memórias pregressas que geram as características para esta seleção. Para um indivíduo aprender é necessário que identifique e associe os estímulos ambientais e arquive as informações relevantes. Por outro lado, a eficiência desta identificação e associação dependeria da atenção além, obviamente, da motivação e memórias formadas previamente (D’Mello e Steckler, 1996).

Recente revisão descreve os mecanismos atencionais como sendo responsáveis pela seleção de informações que ganham acesso à memória operacional. A memória operacional seria um dos componentes fundamentais para a atenção, visto que após a seleção, a representação dos objetos da atenção passa a ser a própria memória. Em um ciclo constante, a atenção é essencial também para a evocação de informação armazenada na memória para sua utilização (Knudsen, 2007). Alguns trabalhos também têm tentado demonstrar o papel da atenção exatamente na ativação cortical seqüencial de informações da memória operacional. Para os autores, a evocação de mais de uma informação da memória operacional só é possível pela ação da atenção que alterna entre as informações, sendo que a escolha desta forma determina a eficiência do resgate da informação (Li et al., 2004 e 2006).

LaBar e colaboradores (1999) descrevem diversas áreas encefálicas ativas tanto em tarefas prioritariamente de memória operacional como em tarefas atencionais, e acreditam que esta intersecção funcional seja devida à necessidade da alocação atencional em ambas as tarefas, indicando que esta função estaria inevitavelmente ativa em qualquer atividade de memória operacional verbal. Assim, além dos campos visuais frontais, cerebelo e do tálamo, diversas áreas fronto-parietais, incluindo os sulcos intraparietal, pré-central ventral e a área motora suplementar intersectam as duas funções cognitivas. Já o córtex pré-motor bilateral, o lóbulo parietal inferior direito, o giro frontal inferior esquerdo e o córtex 
cerebelar direito estariam ativados durante o uso preferencial da memória operacional verbal, enquanto a junção occípito-temporal bilateral e o córtex extraestriado quando a atenção estivesse sendo priorizada (LaBar et al, 1999).

Temos então que muito pouco foi estudado da atenção na DMD para que se possa concluir que as alterações cognitivas sejam decorrentes exclusivamente de um comprometimento da memória. Toda essa correlação entre estas duas funções mentais favorece a idéia de que a atenção possa definitivamente estar também comprometida na doença. E a atenção interferiria tanto nos componentes verbais como nos componentes de execução dos testes de inteligência, permeando assim todas as funções cognitivas avaliadas nos testes neuropsicológicos.

\subsection{Avaliação quantitativa da atenção}

É possível estudar a expressão comportamental dos processos atencionais automáticos e voluntários. Para tanto se considera que: pistas "exógenas" capturam a atenção de maneira ascendente (de baixo para cima), caracterizando a atenção automática, enquanto pistas "endógenas" que requerem o direcionamento do foco atencional de maneira descendente (de cima para baixo) caracterizariam a atenção voluntária (Coull, 1998). Estas são as premissas em que se baseiam as tarefas de orientação espacial da atenção desenvolvidas por Posner (1980).

A tarefa descrita por Posner (1980) se tornou padrão de ouro para testar orientação espacial da atenção, sendo conhecida como tarefa de orientação encoberta de Posner. Nela, os sujeitos são posicionados em frente à tela de um monitor de vídeo com um ponto de fixação central e dois quadrados periféricos. Sua tarefa é responder o mais rapidamente possível a um alvo visual que aparece brevemente em um dos dois quadrados periféricos, enquanto mantêm fixos os olhos no ponto central da tela. Pouco antes do aparecimento do 
alvo, é apresentado outro estímulo visual, periférica ou centralmente. O estímulo periférico pode ser um clareamento rápido de um dos dois quadrados (um estímulo precedente "exógeno", que direciona a atenção dos indivíduos para um local de forma automática). O estímulo precedente central pode ser uma cabeça de seta que aponta para um dos dois lados da tela (um estímulo precedente "endógeno", que requer do indivíduo que direcione seu foco atencional de maneira voluntária para o lado indicado pela cabeça de seta). Havendo ainda uma condição neutra em ambos os testes (na qual a atenção é capturada ou voluntariamente direcionada para ambos os lados da tela), é possível calcular o benefício (redução do tempo de reação) de ter sido alocada a atenção pro local de aparecimento do alvo, ou o custo de ter sido retirada a atenção do local de aparecimento do alvo. Como é de se esperar, os indivíduos respondem de maneira mais rápida ao alvo que aparece no local atendido, e mais lentamente ao alvo que aparece no local desatendido. E a diferença entre o tempo de resposta a um estímulo nestas duas condições (local desatendido e local atendido), é a medida da eficiência da detecção, determinada pela alocação da atenção para o local esperado (Posner, 1980). A esta diferença damos o nome de efeito atencional.

Desde que descrito por Posner em 1980, estas tarefas ou tarefas similares têm sido usadas em diversas situações, inclusive para avaliar a atenção de crianças com patologias envolvendo o SNC. Nestas se incluem a Desordem de Desenvolvimento de Coordenação (DDC) (Wilson et al., 1997; Mandich et al., 2003), o Transtorno de Déficit de Atenção/Hiperatividade (TDAH) (Huang-Pollock e Nigg, 2003) e a Espinha Bífida (Dennis et al., 2005).

Nos testes neuropsicológicos realizados em meninos com DMD, distúrbios específicos de atenção podem passar despercebidos. Os testes de Posner provavelmente detectariam tais distúrbios. No presente estudo utilizamos os testes de Posner para avaliar o desempenho atencional de meninos com Distrofia Muscular de Duchenne por meio das 
formas de mobilização de atenção automática e voluntária. Testamos voluntários com uma tarefa de tempo de reação de escolha de local (respostas com a mão direita caso o estímulo alvo apareça à direita e respostas com a mão esquerda no caso do estímulo alvo aparecer à esquerda) com orientação encoberta da atenção. Avaliamos tanto os tempos de reação (TR) brutos como o benefício e custo da orientação da atenção. Para calcularmos o benefício e o custo incluímos na tarefa um estímulo precedente periférico bilateral e um estímulo central indicando ambos os lados (condição bilateral e neutra, respectivamente). Para reduzirmos a influência da memória operacional nos testes, mantivemos o estímulo precedente na tela até o aparecimento do alvo (LaBar et al, 1999).

Baseado no fato de que a ausência de distrofina na densidade pós-sináptica interfere na eficiência das sinapses (Kim et al., 1995), acreditamos que os mecanismos neurais da atenção podem estar comprometidos nos pacientes com DMD. Como a atenção possibilita a melhora no processamento da informação (Posner, 1980), temos que uma alteração atencional poderia ser interpretada como o comprometimento no processamento, resultando na diminuição na velocidade de resposta a esta informação (ou um aumento nos TR). Temos, porém, que alguns fatores característicos da DMD, como os déficits motores e as alterações na retina, também poderiam levar a esta lentificação da resposta, o que prejudicaria a interpretação dos dados relativos à atenção em si. Assim, optamos por priorizar a análise do efeito atencional, tanto pelo beneficio como pelo custo da atenção, por serem medidas quantitativas da atenção que excluem os componentes de resposta. Desta forma, predissemos que os efeitos atencionais tanto automáticos como voluntários estariam diminuídos no grupo DMD.

Com relação aos TR, estes seriam considerados apenas quando analisados em condições comparativas dentro do mesmo grupo, para minimizar as diferenças entre os grupos determinadas pelos outros fatores que não a própria atenção. 


\section{OBJETIVOS}

\subsection{Objetivo geral}

O presente estudo teve como objetivo investigar o desempenho atencional de meninos portadores de DMD.

\subsection{Objetivos específicos}

1. Contrastar o desempenho de meninos com DMD com o de meninos saudáveis nos testes de atenção automática e atenção voluntária.

2. Verificar a evolução com a idade no desempenho atencional dos meninos com DMD.

3. Verificar se existem assimetrias inter-laterais relacionadas aos tipos de atenção nos meninos com DMD. 


\section{MÉTODOS}

\subsection{Participantes}

Foram estudados 30 indivíduos com DMD atendidos no ambulatório de Distrofia Muscular do Serviço de Neurologia Infantil do Hospital das Clínicas da Faculdade de Medicina da Universidade de São Paulo (HC - FMUSP). Seu diagnóstico baseou-se em quadro clínico caracterizado por perda progressiva de força muscular, elevados níveis de creatina-fosfo-quinase (CPK), histologia muscular compatível com DMD e/ou mutações no gene DMD. Todos eram do sexo masculino, tinham entre 10 e 16 anos de idade, estavam em bom estado geral de saúde, não apresentavam antecedentes adicionais relacionados ao SNC, depressão e/ou em uso de medicamentos antidepressivos. Eram alfabetizados, matriculados e freqüentavam salas normais do ensino fundamental ou do ensino médio. Todos os canhotos de acordo com o resultado obtido com o Questionário de Edinburgh (Oldfield, 1971) foram excluídos (anexo 1).

O grupo controle foi composto de 30 meninos, recrutados em um Núcleo SócioEducativo do Jaguaré, da Prefeitura da Cidade de São Paulo. Suas idades eram semelhantes às dos meninos com DMD. Todos gozavam de boa saúde e não apresentavam antecedentes de doenças neurológicas, mentais ou uso de antidepressivos. Todos eram alfabetizados, matriculados e freqüentavam salas normais do ensino fundamental ou do ensino médio. Todos os canhotos segundo o Questionário de Edinburgh (índice de lateralidade inferior a 0,3) foram excluídos.

Todos os participantes (DMD e controle) realizaram um teste de acuidade visual (anexo 2). Apenas aqueles que apresentavam visão normal ou corrigida tiveram seus resultados considerados. 
O grau de comprometimento motor nos meninos com DMD foi considerado pouco relevante para a realização dos testes, não sendo realizado nenhum teste específico para sua mensuração. Da mesma forma, o possível déficit de processamento visual acarretado pela ausência de distrofina nos fotoreceptores da retina também não serão considerados relevantes para o trabalho. Isto porque, mesmo que a deficiência de distrofina gere lentificação na execução da resposta motora e/ou uma lentificação no processamento perceptual visual dos estímulos, em ambos os casos a resposta comportamental associada seria a elevação dos TR. Assim, partimos da premissa que todos os meninos têm algum grau de fraqueza muscular e de alteração visual, e, apesar dos estímulos serem muito supra-limiares e as respostas exigidas dependerem de movimentos extremamente simples, optamos por considerar o TR apenas quando comparado dentro do próprio grupo, ou em outras análises que desconsideram o componente de resposta, como será explicado posteriormente.

A escolha da faixa etária baseou-se em idade pertencente àquela determinada pelo WISCIII, a Escala de Inteligência Wechsler para crianças, adaptado e padronizado para o Brasil (Figueiredo, 2001).

Este projeto de pesquisa foi submetido à Comissão de Ética em Pesquisa com Seres Humanos do Instituto de Psicologia da Universidade de São Paulo e também à Comissão de Ética do Hospital das Clínicas da Faculdade de Medicina da USP. Todos os responsáveis legais pelos participantes aceitaram que eles participassem do projeto assinando um termo de consentimento livre e esclarecido (anexo 3) após a devida explicação oral e escrita do mesmo. 


\subsection{Materiais}

Os voluntários foram testados individualmente, sob baixo nível de iluminação ambiente, em uma sala no Hospital das Clínicas (grupo Duchenne - GD) e outra no Núcleo Sócio-Educativo do Jaguaré (grupo controle - GC). Eles permaneceram sentados, em frente a uma mesa onde se encontrava um monitor de vídeo de 15 polegadas distante $57 \mathrm{~cm}$ de seus olhos. Neste monitor eram apresentados estímulos visuais. Os voluntários respondiam a alguns destes estímulos pressionando com seus polegares uma ou outra tecla de um mouse, conectado à entrada de jogo de computador, que seguravam sobre suas pernas com ambas as mãos.

Os estímulos eram gerados e as respostas gravadas por um microcomputador IBMPC/AT 486, controlado por programas elaborados com o aplicativo MEL2 - Micro Experimental Laboratory (Psychology Software Tools). A precisão das medidas do tempo de reação (TR) era da ordem de um milésimo de segundo.

\subsection{Procedimentos}

Todos os voluntários com DMD e controles realizaram uma sessão de teste constituída de duas etapas, uma de avaliação da atenção automática e outra de avaliação da atenção voluntária. A ordem destas duas etapas foi balanceada entre os voluntários de cada grupo. A sessão de teste durava no total 50 min.; ela incluía 10 min. para explicação, 05 min. de treinamento e 10 minutos de execução do primeiro teste, seguido de mesmo tempo para explicação, treinamento e execução do segundo teste.

O teste de atenção automática era constituído por dois blocos de 48 tentativas (96 tentativas no total) com um intervalo de aproximadamente 2 minutos entre eles. Antes de ser iniciado o teste, os voluntários recebiam as instruções apropriadas, oralmente e por escrito (anexo 4). A seguir eles realizaram como treino aproximadamente 15 tentativas; 
eventuais problemas de compreensão da tarefa eram corrigidos. Então o teste propriamente tinha início.

Cada tentativa iniciava-se com o aparecimento de uma pequena cruz central (ponto de fixação - PF; com luminância de $28 \mathrm{~cd} / \mathrm{m}^{2}$ ), e dois quadrados periféricos demarcadores de posição $\left(1,50^{\circ}\right.$ de largura por $1,50^{\circ}$ de altura e $0,04^{\circ}$ de borda, de mesma luminância $)$ cujo centro estava disposto $6,8^{\circ}$ à esquerda e à direita do PF. A cor do fundo da tela era cinza escuro (com luminância de $3 \mathrm{~cd} / \mathrm{m}^{2}$ ). Após algum tempo que podia variar aleatoriamente entre 1750 e $2250 \mathrm{~ms}$, ocorria o clareamento da borda de um dos quadrados (luminância $40 \mathrm{~cd} / \mathrm{m}^{2}$ ), que chamaremos de estímulo precedente. Este estímulo ocorria em $1 / 3$ das tentativas no quadrado da esquerda, em $1 / 3$ das tentativas no quadrado da direita $\mathrm{e}$ em $1 / 3$ das tentativas em ambos os quadrados (condição bilateral). $\mathrm{O}$ estímulo precedente durava $100 \mathrm{~ms}$ e era seguido imediatamente pelo estímulo alvo, que era uma linha vertical (luminância de $45 \mathrm{~cd} / \mathrm{m}^{2}, 0,8^{\circ}$ de comprimento e $0,04^{\circ}$ de largura) no interior de um dos quadrados. $\mathrm{O}$ alvo permanecia por $100 \mathrm{~ms}$ na tela; ele ocorria em $50 \%$ das tentativas do lado direito e em $50 \%$ das tentativas do lado esquerdo, sendo que em $1 / 3$ das tentativas aparecia na mesma posição do estímulo precedente, em $1 / 3$ das tentativas aparecia na posição oposta ao estímulo precedente e em $1 / 3$ das tentativas, correspondente à condição bilateral, aparecia do lado esquerdo ou direito igualmente. Assim, considerando os dois blocos, tínhamos 16 tentativas para cada uma das condições: mesma posição do estímulo precedente e do alvo à direita, mesma condição à esquerda, condição oposta entre o estímulo precedente e o alvo à direita e à esquerda, e condição bilateral com alvo à direita ou à esquerda, totalizando 96 tentativas. Essas condições ocorriam aleatoriamente.

Os participantes eram orientados a manter o olhar fixo no centro da tela e a responder ao alvo o mais rápidamente possível, porém procurando não errar, pressionando a tecla da direita do mouse com o polegar direito caso o alvo aparecesse deste lado da tela; 
e pressionar com o polegar esquerdo a tecla da esquerda do mouse caso o alvo aparecesse deste lado da tela (veja a figura 5).

Ao final de cada tentativa era apresentada uma mensagem de acordo com o desempenho do participante. Respostas com latência menor que $150 \mathrm{~ms}$ ou emitidas antes da apresentação do alvo eram consideradas antecipações e a mensagem "ESPERE O ALVO" aparecia no centro da tela. As respostas dadas com uma latência maior que 2000 ms eram considerada omissões e a mensagem "MAIS RÁPIDO" aparecia no centro da tela. Respostas dadas com a mão trocada eram definidas como erros de inversão e a mensagem "RESPONDA COM A MÃO DO LADO DO ALVO" aparecia no centro da tela. As respostas eram consideradas corretas quando eram dadas no intervalo de tempo apropriado e com a mão correspondente ao lado de aparecimento do alvo. Estas respostas eram reforçadas pelo aparecimento no centro da tela do TR em milisegundos. As mensagens duravam 1000 ms. Após o término da mensagem aparecia novamente o PF para iniciar a próxima tentativa.

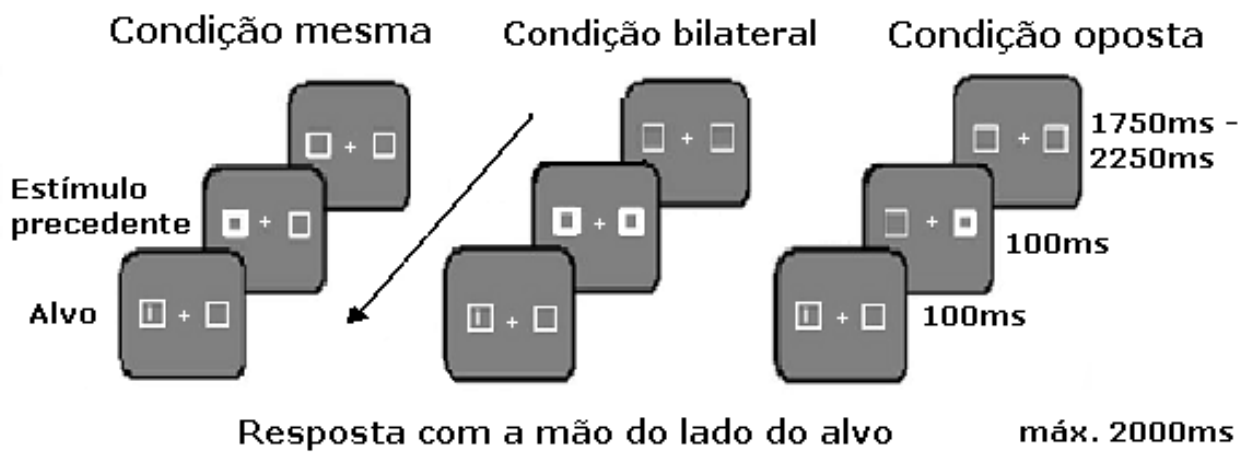

Figura 5: Diagrama representativo da seqüência de apresentações visuais no teste de atenção automática. Após intervalo de $1750 \mathrm{~ms}$ ou $2250 \mathrm{~ms}$, o estímulo precedente (clareamento da borda dos quadrados periféricos) permanecia por $100 \mathrm{~ms} \mathrm{e}$, ao desaparecimento, o alvo era apresentado em um dos dois quadrados, ao qual o participante deveria responder com a mão do lado do alvo, o mais rapidamente possível, porém tentando não cometer erros. 
O teste de atenção voluntária era constituído por dois blocos de 60 tentativas (120 tentativas no total) com intervalo de 5 minutos entre os blocos. Antes de ser iniciado o teste, os participantes recebiam instruções apropriadas por escrito (anexo 5), e oralmente, visto que isto facilitava a compreensão e agilizava o início da sessão. A seguir, os participantes realizavam aproximadamente 20 tentativas, não registradas, para que o experimentador pudesse avaliar a compreensão da tarefa e para minimizar a influência da aprendizagem da tarefa no TR. Após este treino é que era iniciado o teste propriamente.

Cada tentativa iniciava-se com o aparecimento do PF (com luminância de $28 \mathrm{~cd} / \mathrm{m}^{2}$ ) e dois quadrados demarcadores de posição $\left(1,50^{\circ}\right.$ de largura por $1,50^{\circ}$ de altura e $0,04^{\circ}$ de borda, com mesma luminância) cujo centro estava disposto $6,8^{\circ}$ à esquerda e à direita do PF. A cor do fundo da tela era cinza escuro (com luminância de $3 \mathrm{~cd} / \mathrm{m}^{2}$ ). Após algum tempo que poderia variar aleatoriamente entre 1750 e $2250 \mathrm{~ms}$, aparecia uma pequena "cabeça" de seta no centro da tela (largura $0,2^{\circ}$ e altura o, $4^{\circ}$, com luminância de $40 \mathrm{~cd} / \mathrm{m}^{2}$ ), que chamamos de pista. Este estímulo em $1 / 3$ das tentativas apontava para o quadrado da esquerda, em $1 / 3$ das tentativas apontava para o quadrado da direita e em $1 / 3$ das tentativas apontava para ambos os quadrados simultaneamente (condição neutra). A pista permanecia na tela até a resposta ser executada. O alvo aparecia $1000 \mathrm{~ms}$ após o surgimento da pista e durava $100 \mathrm{~ms}$. O alvo era uma linha vertical $\left(0,8^{\circ}\right.$ de comprimento e $0,04^{\circ}$ de largura, luminância de $45 \mathrm{~cd} / \mathrm{m}^{2}$ ) no interior de um dos quadrados e ocorria em $50 \%$ das tentativas do lado direito e em $50 \%$ das tentativas do lado esquerdo. Em $60 \%$ das tentativas o alvo aparecia no local indicado pela pista (condição válida), em $20 \%$ das tentativas aparecia na posição oposta à indicada pela pista (condição inválida) e em $20 \%$ das tentativas, correspondente à condição neutra, do lado esquerdo ou direito igualmente. Assim, considerando os dois blocos, eram 36 tentativas para a condição válida à direita, 36 tentativas para a condição válida à esquerda, e 12 tentativas nas demais condições 
(condição inválida à direita, condição inválida à esquerda, condição neutra com alvo à direita e situação neutra com alvo à esquerda) totalizando 120 tentativas. Essas condições ocorriam aleatoriamente.

Os participantes eram instruídos a manter o olhar fixo no centro da tela e a orientar sua atenção na direção apontada pela cabeça de seta sem mexer os olhos. Deveriam então responder o mais rapidamente possível, porém tentando não errar, pressionando a tecla da direita do mouse com o polegar direito caso o alvo aparecesse deste lado da tela; e deveriam pressionar a tecla da esquerda do mouse com o polegar esquerdo caso o alvo aparecesse deste lado da tela (veja a figura 6).

Ao final de cada tentativa era apresentada uma mensagem relacionada com o desempenho, como descrito para a atenção automática.

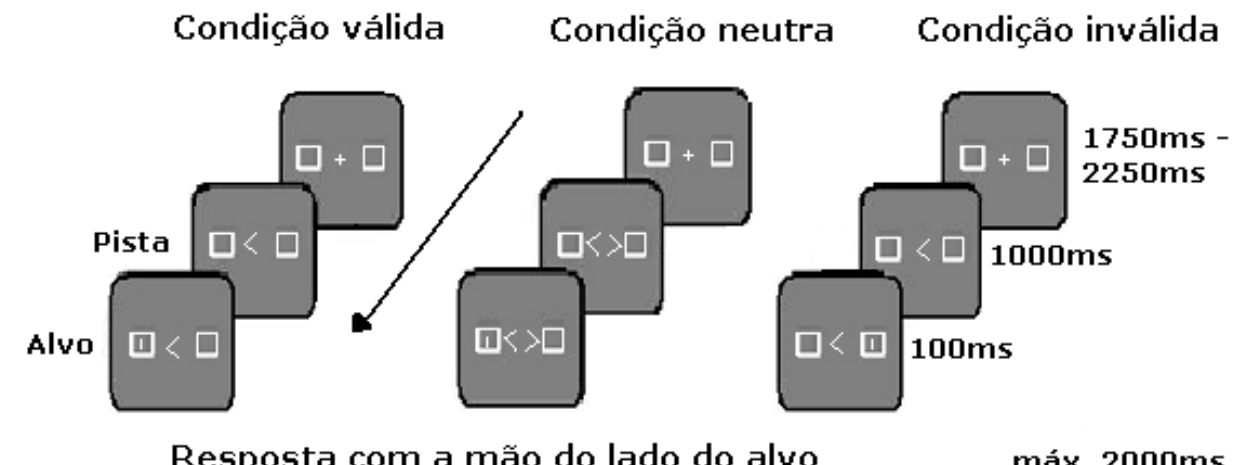

Figura 6: Diagrama representativo da seqüência de apresentações visuais no teste de atenção voluntária. Após intervalo de $1750 \mathrm{~ms}$ ou $2250 \mathrm{~ms}$, a pista ("cabeça" de seta central) permanecia por $1000 \mathrm{~ms}$ até o aparecimento do alvo em um dos dois quadrados, ao qual o participante deveria responder com a mão do lado do alvo, o mais rapidamente possível, porém tentando não cometer erros.

A verificação dos movimentos oculares durante o teste de atenção voluntária era feita com observação direta do avaliador que se posicionava lateralmente ao monitor de vídeo. Após o treino, quando eram feitas correções orais, o voluntário realizava a tarefa sob observação constante do orientador. Caso houvesse movimentação ocular, era chamada 
a atenção para correção. Três ou mais correções durante o teste a criança era posteriormente eliminada por não colaboração. Devido à dificuldade de utilizar métodos mais sofisticados de escaneamento dos movimentos oculares em ambiente clínico, outros trabalhos com crianças também relatam avaliação direta do avaliador (Dennis et al., 2005). Em trabalhos com adultos jovens, o uso de escaneamento do movimento ocular em tarefas de atenção voluntária similares à nossa não evidenciou movimentos em mais do que $2 \%$ das tentativas, sem haver necessidade de exclusão de participantes por este motivo (Riggio e Kirsner, 1997; Rosen et al., 1999; Kincade et al., 2005).

A inclusão da pista neutra se deveu à necessidade de conhecimento mais detalhado dos efeitos comportamentais das pistas automática e voluntária. Este tipo de pista permite a análise do benefício e do custo da alocação da atenção, e pode revelar diferenças específicas nos padrões de desempenho entre pacientes e sujeitos saudáveis (Pollux e Robertson, 2001).

\subsection{Análise Estatística}

Para cada voluntário foi calculada a média das medianas dos tempos de reação (TR) nos dois blocos para cada condição. Também, para cada voluntário, foram calculados os números totais de omissões, respostas antecipadas e invertidas nos dois blocos para cada condição.

Os dados de TR foram submetidos a uma análise de variância para medidas repetidas, tendo como fatores o grupo (GC e GD), o tipo de atenção (automática e voluntária) e o tipo de estímulo precedente (mesmo/válido, oposto/inválido, bilateral/neutro). Quando apropriado, os dados foram analisados com o teste post-hoc de Newman-Keuss. Foi adotado nível de significância de 0,05. 
Os dados de acurácia foram analisados com o teste de Kolmogorov-Smirnov. Basicamente, foram comparados os números de erros de cada tipo entre os grupos GC e GD em cada condição. O nível de significância foi ajustado para o número de comparações realizadas (dividindo-se 0,05 pelo número de comparações). 


\section{RESULTADOS}

Dos 30 meninos do GC, cinco foram excluídos. Um deles apresentava acuidade visual reduzida, dois não colaboraram com o teste e dois eram canhotos. Dos 30 meninos do grupo experimental, também cinco foram excluídos. Um deles apresentava acuidade visual reduzida, três não colaboraram com o teste e um teve seu diagnóstico corrigido para Distrofia Muscular de Becker.

Não houve exclusão de voluntários por movimentação ocular excessiva no teste de atenção voluntária (três ou mais movimentações). A não colaboração se deu basicamente por falta de motivação ou cansaço, com os meninos interrompendo a execução do teste.

Os dois grupos não diferiram em relação à idade (média $\pm \mathrm{dp}: 12,04 \pm 2,01$ anos para o GC e 12,04 $\pm 2,17$ anos para o GD; t-value $<0,001, \mathrm{p}>0,05)$.

Em ambos os grupos havia 24 voluntários destros (índice de lateralidade maior que $+0,3)$ e 1 voluntário ambidestro (índice de lateralidade entre $-0,3$ e $+0,3$ ), totalizando 25 meninos por grupo.

Os dados clínicos dos voluntários com DMD podem ser visualizados na Tabela 2. 
Tabela 2. Dados clínicos dos voluntários com DMD que participaram dos experimentos (Idade: média $\pm \mathrm{dp}$ )

\begin{tabular}{|c|c|c|c|c|}
\hline DUCHENNE & LOCOMOÇÃO & IDADE & $\begin{array}{l}\text { DOMINÂNCIA } \\
\text { MANUAL }\end{array}$ & $\begin{array}{l}\text { TEMPO APROXIMADO } \\
\text { DE COTICOTERAPIA }\end{array}$ \\
\hline 1 & deambulante & 11 & Direita & 2 anos \\
\hline 2 & deambulante & 12 & Direita & 4 anos \\
\hline 3 & cadeirante & 11 & Direita & 3 anos \\
\hline 4 & deambulante & 16 & Direita & 8 anos \\
\hline 5 & deambulante & 11 & Direita & 5 anos \\
\hline 6 & cadeirante & 10 & Direita & 6 anos \\
\hline 7 & cadeirante & 11 & Ambidestro & 5 anos \\
\hline 8 & deambulante & 10 & Direita & 2 anos \\
\hline 9 & cadeirante & 15 & Direita & 5 anos \\
\hline 10 & cadeirante & 16 & Direita & 1 ano \\
\hline 11 & deambulante & 11 & Direita & 3 anos \\
\hline 12 & deambulante & 11 & Direita & 2 anos \\
\hline 13 & cadeirante & 14 & Direita & 5 anos \\
\hline 14 & deambulante & 11 & Direita & 2 anos \\
\hline 15 & deambulante & 10 & Direita & 5 anos \\
\hline 16 & cadeirante & 15 & Direita & 7 anos \\
\hline 17 & cadeirante & 16 & Direita & 4 anos \\
\hline 18 & cadeirante & 11 & Direita & 6 meses \\
\hline 19 & deambulante & 12 & Direita & 6 anos \\
\hline 20 & cadeirante & 15 & Direita & 4 meses \\
\hline 21 & cadeirante & 10 & Direita & 1 ano \\
\hline 22 & deambulante & 10 & Direita & 4 anos \\
\hline 23 & deambulante & 10 & Direita & 6 meses \\
\hline $24 *$ & cadeirante & 11 & Direita & 4 meses \\
\hline $25^{*}$ & cadeirante & 11 & Direita & 4 meses \\
\hline
\end{tabular}

TOTAL 12 deambulantes $12,04 \pm$ 13 cadeirantes 2,17 anos

* Estes voluntários eram irmãos gêmeos. Os demais participantes não apresentavam irmãos com DMD. 


\subsection{Tempos de Reação}

A análise de variância dos TR evidenciou efeito principal para os três fatores considerados, a saber, grupo $\left(\mathrm{F}_{1,48}=8,995 ; \mathrm{p}=0,004\right)$, tipo de atenção $\left(\mathrm{F}_{1,48}=13,406\right.$; $\mathrm{p}<0,001)$ e tipo de estímulo precedente $\left(\mathrm{F}_{2,96}=151,108 ; \mathrm{p}<0,001\right)$. Os TR foram maiores para o GD do que para o GC e menores para a atenção voluntária do que para a atenção automática.

Houve um efeito do estímulo precedente para ambos os grupos no teste de atenção automática, porém apenas para o GD no teste de atenção voluntária. Assim, no teste de atenção automática, o TR na condição mesma foi menor do que o TR na condição oposta tanto para o grupo GC como para o GD $(312 \mathrm{~ms} \pm 12 \mathrm{~ms}$ e $369 \mathrm{~ms} \pm 10 \mathrm{~ms} ; \mathrm{p}<0,001$ para o GC; $371 \mathrm{~ms} \pm 18 \mathrm{~ms}$ e $431 \mathrm{~ms} \pm 15 \mathrm{~ms}, \mathrm{p}<0,001$ para o grupo GD, nas condições mesma e oposta, respectivamente). No teste de atenção voluntária, também houve diferença entre os TR nas condições válida e inválida para o GD $(325 \mathrm{~ms} \pm 13 \mathrm{~ms}$ e $406 \mathrm{~ms} \pm 18 \mathrm{~ms}$, $\mathrm{p}<0,001$, nas condições válida e inválida, respectivamente). Porém o mesmo efeito não foi verificado no grupo GC $(316 \mathrm{~ms} \pm 9 \mathrm{~ms}$ e $334 \mathrm{~ms} \pm 9 \mathrm{~ms}, \mathrm{p}=0,14$ nas condições válida e inválida, respectivamente).

Houve tendência de interação entre os fatores grupo e tipo de atenção $\left(\mathrm{F}_{1,48}=3,410\right.$; $\mathrm{p}=0,071)$. A análise posterior referente a esta interação evidenciou que os TR foram maiores para o GD do que para o GC tanto no caso da atenção automática $(\mathrm{p}<0,001)$ quanto no caso da atenção voluntária $(\mathrm{p}<0,001)$. Enquanto os TR da atenção voluntária não diferiram dos TR da atenção automática para o $\mathrm{GC}(\mathrm{p}=0,20)$, os TR da atenção voluntária foram menores do que os TR da atenção automática para o GD $(\mathrm{p}<0,001)$.

Houve interação entre os fatores grupo, tipo de atenção e tipo de estímulo precedente $\left(\mathrm{F}_{2,96}=7,456 ; \mathrm{p}<0,001\right)$. A análise posterior referente a esta interação mostrou que, no caso da atenção automática, os TR foram maiores para o GD do que para o GC nas 
condições mesma $(p<0,001)$, bilateral $(p<0,001)$ e oposta $(p<0,001)$. No caso da atenção voluntária, os TR não diferiram entre os dois grupos na condição válida $(\mathrm{p}=0,249)$, mas foram maiores para o GD do que para o GC nas condições neutra $(p<0,001)$ e inválida $(p<0,001)$. A tabela 3 e a figura 7 sumarizam e ilustram esses resultados.

Tabela 3. Médias ( \pm e.p.m) em milissegundos dos tempos de reação de cada grupo nas três condições nos dois testes.

\begin{tabular}{ccccccc}
\hline \multirow{2}{*}{ Grupos } & \multicolumn{2}{c}{ Atenção Automática } & \multicolumn{3}{c}{ Atenção Voluntária } \\
& Mesma & Oposta & Bilateral & Válida & Inválida & Neutra \\
\hline Controle & $312( \pm 12)$ & $369( \pm 10)$ & $328( \pm 9)$ & $316( \pm 9)$ & $334( \pm 9)$ & $327( \pm 9)$ \\
Duchenne & $371( \pm 18)$ & $431( \pm 15)$ & $389( \pm 15)$ & $325( \pm 13)$ & $406( \pm 18)$ & $362( \pm 14)$ \\
\hline
\end{tabular}

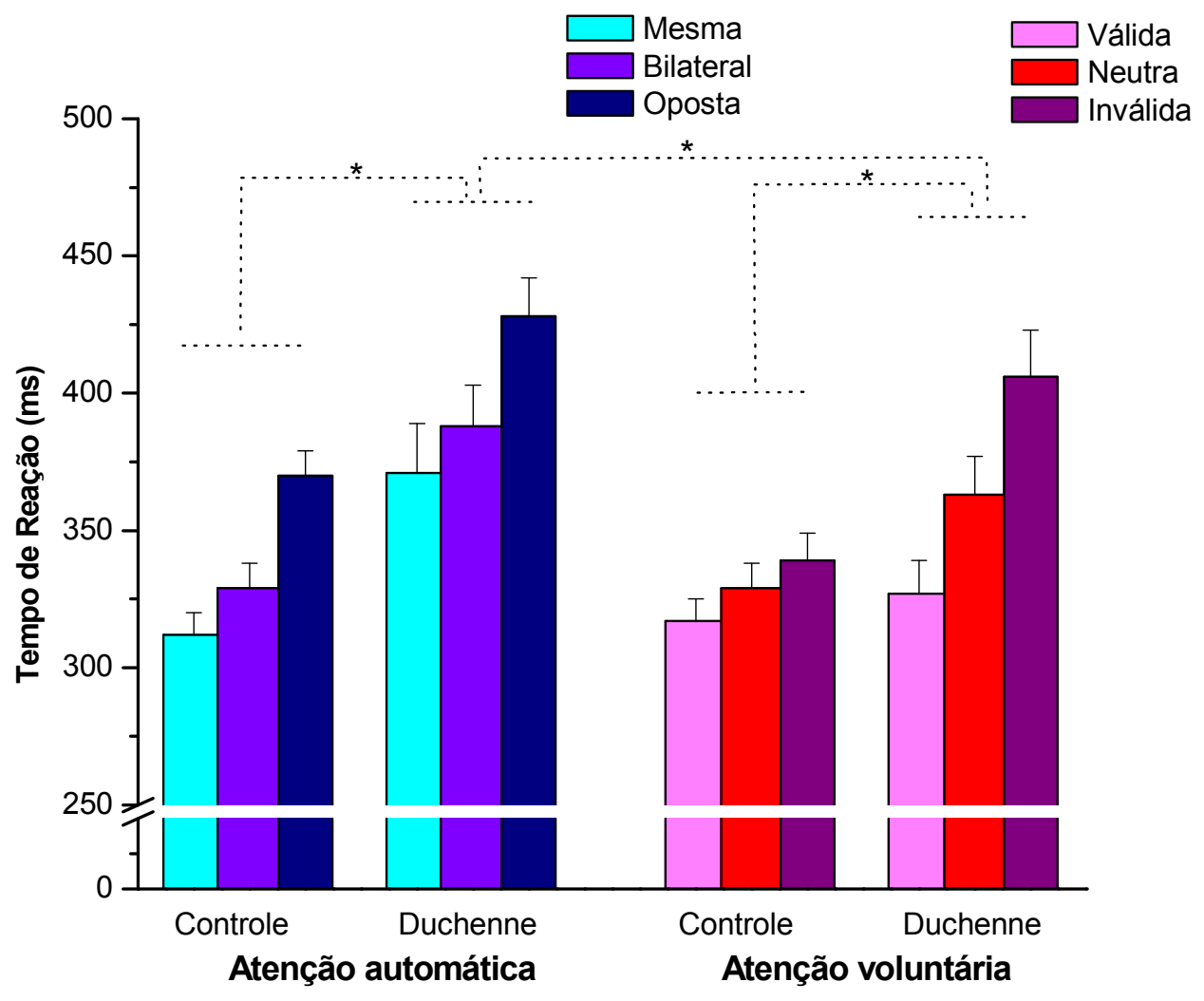

Figura 7. Média (土e.p.m) dos tempos de reação, dos grupos Controle e Duchenne, nas condições mesma, neutra e oposta no teste de atenção automática (barras à esquerda); e condições válida, neutra e inválida no teste de atenção voluntária (barras à direita). ${ }^{*} \mathrm{p}<0,001$. 
Foi feita uma análise de variância adicional dos TR considerando-se como quarto fator a mão utilizada para responder ao estímulo alvo. Nesta análise, diferentemente das anteriores, considerou-se a média dos TR em cada condição e não a mediana em virtude do número relativamente pequeno e desigual de TR para cada condição (veja Miller, 1988). Nenhuma diferença significativa foi encontrada envolvendo o fator mão. Os demais resultados desta análise replicaram os resultados obtidos com as análises utilizando medianas dos TR.

\subsection{Benefício e Custo}

O benefício e o custo da orientação da atenção automática e da atenção voluntária foram calculados respectivamente subtraindo-se o TR na condição mesma/válida do TR na condição bilateral/neutra e o TR na condição bilateral/neutra do TR na condição oposta/ inválida. Os dados assim obtidos foram submetidos a uma análise de variância para medidas repetidas, tendo como fatores o grupo (GC e GD), o tipo de atenção (automática e voluntária) e o tipo de efeito (custo/benefício).

Esta análise revelou um efeito principal para os fatores grupo $\left(\mathrm{F}_{1,48}=21,786\right.$; $\mathrm{p}<0,001)$ e tipo de efeito $\left(\mathrm{F}_{1,48}=7,186 ; \mathrm{p}=0,010\right)$, mas não para o fator tipo da atenção $(p=0,322)$. O GD apresentou um efeito atencional (benefício mais custo) maior do que o GC. O custo foi maior do que o benefício.

Houve interação entre os fatores grupo e tipo de atenção $\left(F_{1,48}=10,818 ; p=0,002\right)$ e entre os fatores tipo de atenção e tipo de efeito $\left(\mathrm{F}_{1,48}=4,401 ; \mathrm{p}=0,041\right)$.

A análise posterior referente à primeira interação acima evidenciou que o efeito atencional não diferiu entre os dois grupos no caso da atenção automática ( $p=0,846)$, mas foi maior no GD do que no $\mathrm{GC}$ no caso da atenção voluntária $(\mathrm{p}<0,001)$. O efeito atencional foi menor para a atenção voluntária do que para a atenção automática no caso 
do GC ( $p=0,004)$, mas não diferiu entre estes dois tipos de atenção, no caso do GD $(\mathrm{p}=0,112)$.

A análise posterior referente à segunda interação revelou que na atenção automática, o benefício foi menor do que o custo para ambos os grupos $(\mathrm{p}=0,014)$, enquanto na atenção voluntária não houve diferença entre benefício e custo da pista $(\mathrm{p}=0,842)$. $\mathrm{O}$ custo foi menor na atenção voluntária do que na atenção automática $(p=0,042)$, mas o benefício não diferiu entre os dois tipos de atenção $(p=0,382)$.

A tabela 4 e a figura 8 sumarizam e ilustram esses resultados.

Tabela 4. Médias ( \pm e.p.m) em milissegundos dos efeitos de benefício e de custo dos grupos Controle e Duchenne nos testes de atenção automática e atenção voluntária.

\begin{tabular}{ccccc}
\hline & \multicolumn{2}{c}{ Automática } & \multicolumn{2}{c}{ Voluntária } \\
Grupos & Benefício & Custo & Benefício & Custo \\
\hline Controle & $16( \pm 5)$ & $41( \pm 4)$ & $11( \pm 7)$ & $7( \pm 4)$ \\
Duchenne & $18( \pm 6)$ & $42( \pm 6)$ & $37( \pm 5)$ & $44( \pm 12)$ \\
\hline
\end{tabular}

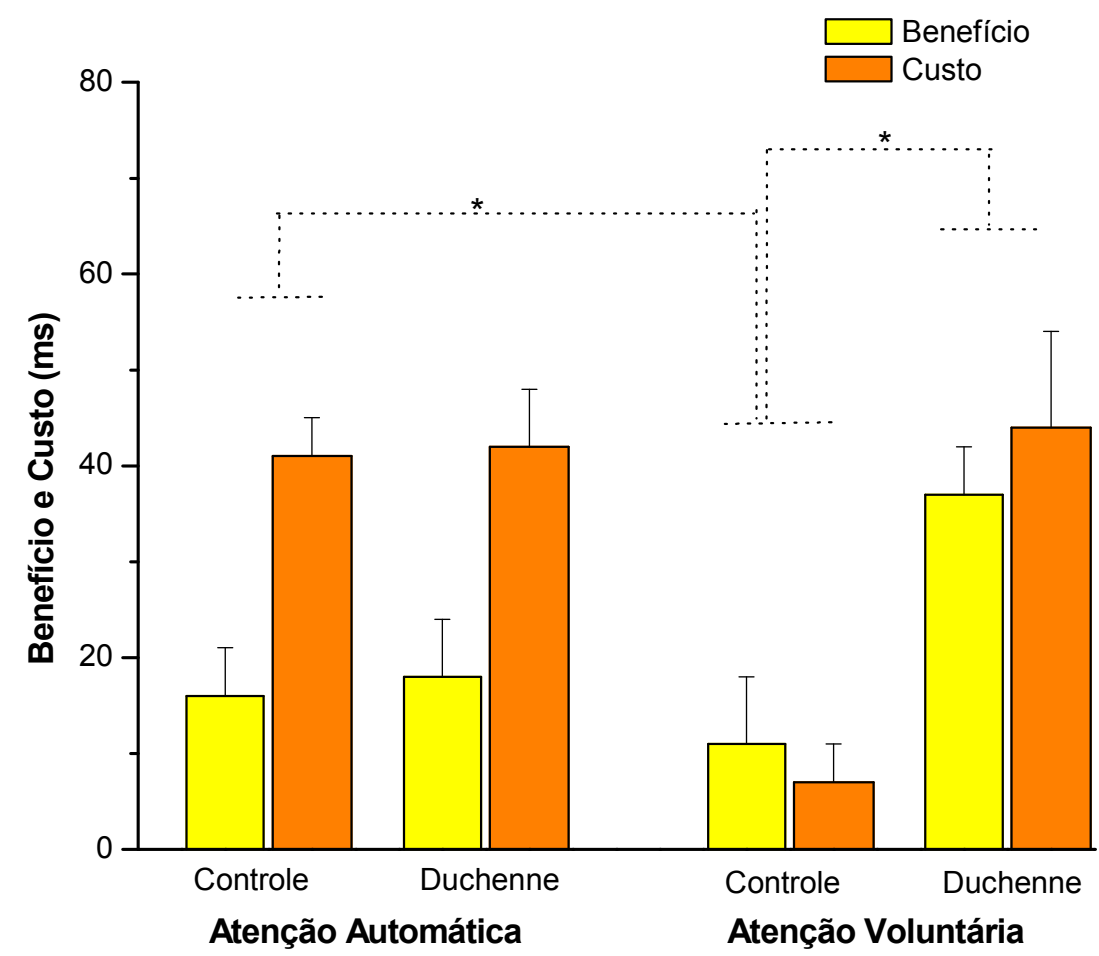

Figura 8. Média ( \pm e.p.m) dos efeitos de benefício e custo em milissegundos da pista sobre o alvo para os grupos Controle e Duchenne nos testes de atenção automática (barras à esquerda) e de atenção voluntária (barras à direita). ${ }^{*} \mathrm{p}<0,01$. 
Foi feita uma análise de variância adicional do benefício e custo considerando-se como quarto fator a mão utilizada para responder ao estímulo alvo. Nesta análise, novamente, considerou-se a média dos TR em cada condição e não a mediana em virtude do número relativamente pequeno e desigual de TR para cada condição (veja Miller, 1988). Nenhuma diferença significativa foi encontrada envolvendo o fator mão. Os demais resultados desta análise replicaram os resultados obtidos com as análises utilizando medianas dos TR.

\subsection{Acurácia}

Não foram observadas diferenças entre o número de erros de antecipação dos grupos GC e GD no teste de atenção automática $(3,0 \pm 0,69$ e 2,96 $\pm 0,79$ erros, $p>0,10$, respectivamente) e no teste de atenção voluntária $(4,08 \pm 0,56$ e 5,28 $\pm 0,92$ erros, $\mathrm{p}>0,10$, respectivamente). $\mathrm{O}$ mesmo aconteceu para os erros de omissão no teste de atenção automática $(0,12 \pm 0,07,0,16 \pm 0,07$ e $0,28 \pm 0,09$ para o GC e $0,08 \pm 0,06,0,16 \pm 0,07$ e $0,56 \pm 0,21$, para o grupo GD, respectivamente nas condições mesma, oposta e bilateral, $\mathrm{p}>0,10)$ e no teste de atenção voluntária $(0,72 \pm 0,27,0,16 \pm 0,07$ e $0,12 \pm 0,07$, para o grupo GC e $0,76 \pm 0,28,0,44 \pm 0,17$ e $0,16 \pm 0,07$, para o grupo GD, respectivamente nas condições válida, inválida e neutra, $\mathrm{p}>0,10)$.

Houve, no entanto, diferença entre o número de erros de inversão na condição inválida no teste de atenção voluntária entre os grupos GC e GD (respectivamente 0,36 \pm $0,15$ e $1,72 \pm 0,34, p<0,001)$. Nas demais condições não houve diferença significativa entre os dois grupos, tanto no teste de atenção automática $(0,72 \pm 0,26,2,68 \pm 0,38$ e 1,28 $\pm 0,31$ para o grupo CG e $0,68 \pm 0,22,2,84 \pm 0,39$ e $0,96 \pm 0,19$ para o GD, respectivamente nas condições mesma, oposta e bilateral) como no teste de atenção voluntária $(0,84 \pm 0,21$ e 
$0,60 \pm 0,15$ para o grupo $\mathrm{GC}$ e 1,24 $\pm 0,31$ e $0,32 \pm 0,14$ para o grupo GD, respectivamente nas condições válida e neutra). A figura 9 ilustra esses resultados.

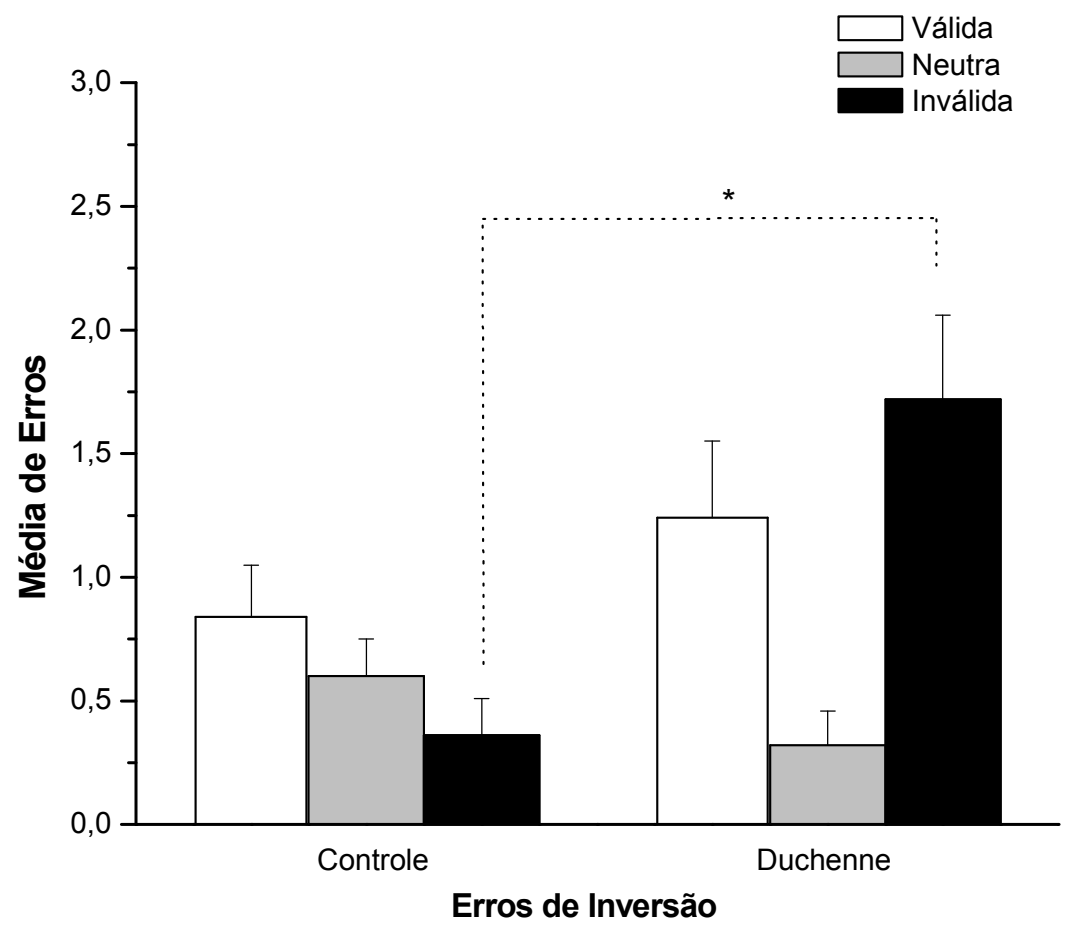

Figura 9. Número total de erros de inversão nas condições válida, neutra e inválida dos grupos Controle e Duchenne no teste de atenção voluntária; * $\mathrm{p}<0,001$.

\subsection{Correlação entre a idade e o efeito atencional nos meninos com DMD.}

Foi ainda realizada uma análise de correlação entre o efeito atencional (diferença entre os TR nas condições oposta/inválida e mesma/válida) tanto automático como voluntário e a idade dos meninos com DMD, de forma a verificar a evolução do comportamento atencional em relação à idade. Para isso foi utilizado o teste de correlação de Pearson, sendo adotado nível de significância de $\mathrm{p}<0,05$.

Não foi observada uma correlação significativa entre o efeito atencional no teste de atenção automática e a idade dos pacientes, com índice de correlação $\mathrm{r}=0,27, \mathrm{p}>0,05$ (veja figura 10). 


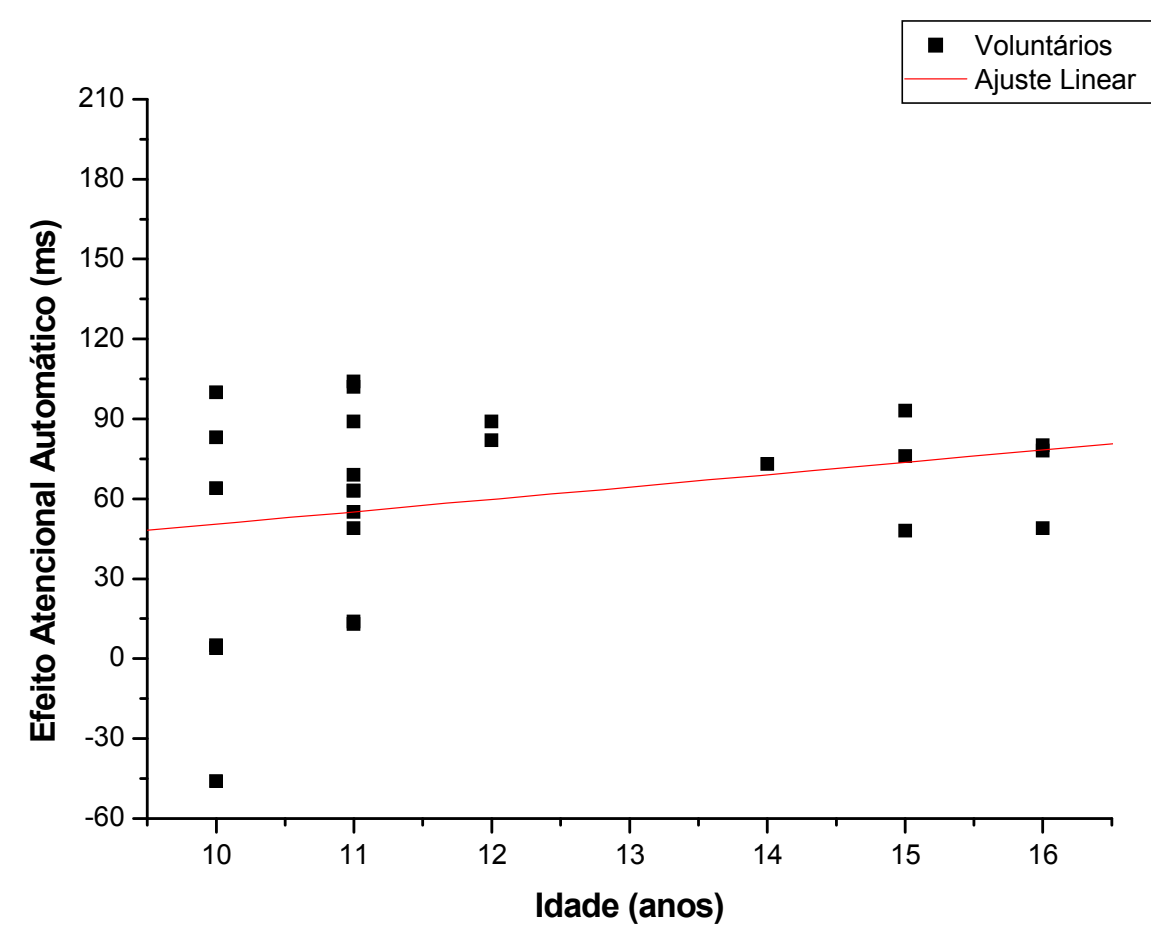

Figura 10. Correlação entre o efeito atencional automático e a idade para os meninos com DMD. $\mathrm{p}>0,05$.

Já o efeito atencional no teste de atenção voluntária apresentou uma correlação negativa com a idade dos pacientes, evidenciando uma diminuição do efeito atencional com o aumento da idade (indice de correlação $\mathrm{r}=-0,40, \mathrm{p}<0,05$ ). Apesar do "p" significativo, este apenas determina que há uma correlação entre os fatores que, no caso, foi negativa. Em análises de correlação, porém, o "r" é mais importante ppois é ele que determina a força da correlação, e $-0,40$ representa uma correlação apenas moderada. Assim, podemos interpretar este dado como uma tendência dos meninos mais velhos com DMD apresentarem um efeito atencional menor, aproximando-se dos dados apresentados pelo GC, e sugerindo uma melhora dos distúrbios atencionais com a idade. A figura 11 ilustra esses dados. 


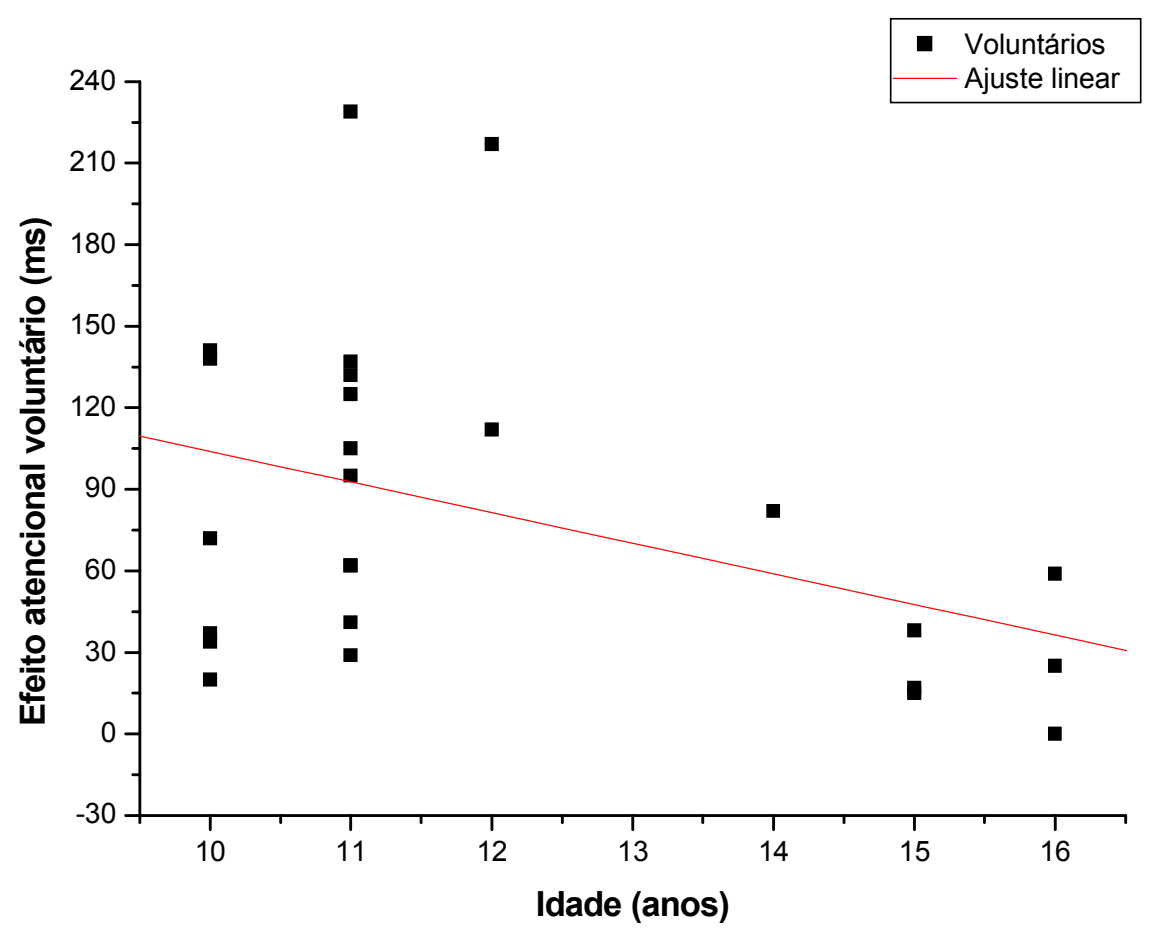

Figura 11. Correlação entre o efeito atencional voluntário e a idade para os meninos com DMD. $\mathrm{p}<0,05$. 


\section{DISCUSSÃO}

Pudemos observar em nossos resultados que o tempo de reação (TR) do grupo de meninos com DMD (GD) foi constantemente maior que o grupo controle (GC) tanto no teste de atenção automática como no teste de atenção voluntária, porém o efeito atencional (benefício mais custo) só diferiu do GC no teste de atenção voluntária. Além disso, o GD apresentou TR menores no teste de atenção voluntária em relação ao teste de atenção automática; o que não aconteceu com o GC.

Assim, não foram encontrados efeitos atencionais menores no GD nos testes como havíamos previsto em nossa hipótese inicial. Porém, nossos dados sugerem que os pacientes com Distrofia Muscular de Duchenne apresentam alteração no controle da alocação dos recursos atencionais, mais evidenciada no teste de atenção voluntária.

\subsection{Atenção automática}

No teste de atenção automática, o aumento dos TR com preservação do efeito atencional dos meninos com Duchenne em relação ao GC parece ser decorrente da falta de preparação motora adequada para a resposta ao alvo em um intervalo curto, de $100 \mathrm{~ms}$. Poderíamos pensar inicialmente que a lentificação decorreria apenas do retardo na execução do ato motor de pressionar as teclas, visto que na DMD o órgão efetor está comprovadamente comprometido. Ou ainda, conforme sugerimos na introdução, os TR poderiam ser mais altos devido a um prejuízo na percepção visual, já que pouco se sabe sobre as alterações na acuidade visual que a falta de distrofina provoca.

Contudo, ao analisarmos os TR na atenção voluntária, quando é possível uma melhor preparação motora (visto que há um intervalo longo, de $1000 \mathrm{~ms}$ ) temos os TR iguais na condição válida nos dois grupos. Assim, parece haver um prejuízo na preparação 
motora para a resposta nos meninos com DMD, sendo necessário um tempo maior para que eles consigam reagir de forma mais similar à dos sujeitos saudáveis. Visto que o efeito atencional na atenção automática foi idêntico para os dois grupos (benefício e custo iguais), a atenção espacial automática não estaria alterada nos meninos com DMD, mas os dados sugerem que poderia haver um distúrbio no que chamamos de atenção temporal.

A atenção temporal pode ser entendida como o preparo para perceber estímulos e/ou executar respostas em um momento particular. As expectativas sobre quando um evento deve ocorrer, analogamente às expectativas de onde o evento deve ocorrer, pode ser utilizado para otimizar as respostas comportamentais (Coull \& Nobre, 1998). As autoras encontraram uma rede comum em regiões frontoparietais tanto para a atenção espacial como temporal, porém, com lateralizações opostas (Coull e Nobre, 1998). Coull e col. (2000), registrando o potencial relacionado ao evento (PRE), mostraram ainda que em tarefas de baixa demanda perceptual, como em testes de detecção, a atenção temporal influencia basicamente os processos motores e não os processos perceptuais. Assim, haveria uma íntima relação entre a atenção temporal e o processamento motor para a resposta, com a atenção temporal facilitando a preparação motora (Coull et al., 2000).

Em nosso trabalho os testes utilizados foram de baixa demanda perceptual (detecção, com discriminação apenas de local, mas não de forma), e também em ambos os testes utilizamos apenas um intervalo entre os estímulos, sendo de $100 \mathrm{~ms}$ no teste de atenção automática e de $1000 \mathrm{~ms}$ no teste de atenção voluntária. Isto sugere que haja um forte componente de atenção temporal, ou seja, que haja um forte peso das pistas temporais para a programação das respostas ao alvo, já que a previsibilidade é máxima por haver apenas um intervalo em cada teste.

Assim, no teste de atenção automática, o curto intervalo foi insuficiente para o grupo GD obter uma preparação motora adequada, gerando uma lentificação nas respostas 
nas três condições quando comparadas às respostas do GC. Já no teste de atenção voluntária, no qual há intervalo longo entre os estímulos, apesar dos TR ainda mais altos, o GD conseguiu atingir um desempenho ótimo na condição válida, na qual os TR são iguais para os dois grupos. A facilitação dada pela informação temporal no teste de atenção voluntária para meninos com DMD fica mais evidente quando observamos a diminuição estatisticamente significante do TR do GD na condição bilateral no teste de atenção automática (389 ms) para a condição neutra no teste de atenção voluntária (362 ms). Já para o GC, quando comparamos as mesmas situações, observamos que os TR se mantiveram iguais nas condições neutras dos dois testes $(328 \mathrm{~ms}$ no teste de atenção automática e 327 ms no teste de atenção voluntária). Hackley e Valle-Inclán (2003) relatam que alterações no TR causadas por uma pista neutra (informação apenas temporal, visto que não há informação espacial) se devem principalmente por um efeito nãoespecífico no sistema motor, atuando em estágios precoces de seleção de resposta. Esses dados são ainda fortalecidos por trabalho recente, que evidenciou, por meio do potencial relacionado ao evento, que a atenção temporal influencia muito claramente os processos decisionais em tarefas de TR, e tem pouca atuação nos estágios mais precoces, de percepção do estímulo (Hackley et al, 2007).

Isto esugere que os meninos com Duchenne apresentam um comprometimento no uso da pista temporal como facilitadora da preparação motora. Enquanto o GC consegue utilizar a pista temporal preditiva de $100 \mathrm{~ms}$, o grupo GD consegue obter a facilitação para a resposta mais rápida ao alvo apenas quando a duração da pista é maior, no caso, 1000 ms. Assim, enquanto o processamento perceptual da pista espacial automática está preservado nos meninos com DMD, evidenciado pelo efeito similar com o GC do benefício e do custo da pista periférica, o processamento da pista temporal se mostra alterado. Isto gera uma 
lentificação na reposta pelo comprometimento da preparação motora à resposta ao alvo, levando ao aumento dos TR no teste de atenção automática.

Perchet \& Garcia-Larrea (2005) descrevem haver uma lentificação das respostas em crianças saudáveis quando comparadas com adultos que, pelos exames de PRE, está relacionada ao período entre a pista e o alvo, associado aos processos antecipatórios/ preparatórios à resposta. Os autores excluem que a lentificação seja devida à atenção espacial ou à identificação dos estímulos. Assim, isso seria o resultado da falha no desenvolvimento de estratégias antecipatórias às respostas a serem executadas. Estes dados vão de encontro com os nossos, pois parece que os meninos com DMD apresentam esse mesmo padrão de alterado no desenvolvimento destas estratégias antecipatórias, sendo que, ao compará-los com sujeitos da mesma faixa etária, sugere que seria decorrente de um atraso na aquisição deste controle. Como em nosso trabalho foram realizados dois testes com características temporais distintas, pudemos observar que a presença de mais condições informativas de tempo permite um melhor desempenho preparatório, algo que no trabalho de Perchet \& Garcia-Larrea (2005) não era possível observar. Assim, nossos dados sugerem que os meninos com DMD apresentam um comprometimento na capacidade de se prepararem adequadamente para responder a estímulos, como crianças mais novas, porém principalmente quando a pista temporal é curta, com melhora significativa deste padrão ao obterem mais condições temporais para responderem.

Além da possibilidade de haver um prejuízo na atenção temporal, outra possibilidade é a de que haja um atraso na maturação do sistema atencional, já que há uma diminuição nos TR em tarefas atencionais é diretamente proporcional ao aumento da idade na infância e na adolescência. Assim, crianças mais novas têm TR maiores que crianças mais velhas e que adolescentes, com a maturação cortical (em especial do córtex cingulado direito) levando a uma maior eficiência para realizar uma tarefa de atenção (Casey et al, 
1997). Temos, então, que os TR aumentados nos meninos com DMD podem expressar um prejuízo na atenção temporal ou um atraso em todo o sistema atencional. $\mathrm{O}$ comprometimento motor da doença, porém, dificulta a certeza em relação a este ponto. Testes futuros que excluam componentes motores pra resposta poderão elucidar mais precisamente estes achados.

Poderíamos, por fim, pensar ainda que a lentificação maior observada neste teste em relação ao teste de atenção voluntária deva-se ao comprometimento perceptual gerado pela alteração sensorial causada pela falta de distrofina nos fotorreceptores da retina (Schimtz and Drenckhahn, 1997), que poderia interferir na velocidade de processamento dos estímulos. No caso, o estímulo precedente muito rápido no teste de atenção automática (100 ms) poderia não ser processado adequadamente como o é no caso do teste de atenção voluntária, na presença de maior tempo de permanência do E1 na tela $(1000 \mathrm{~ms})$. Porém, caso isso fosse verdade, o que observaríamos seria uma alteração (ou até a ausência) de efeito do estímulo precedente sobre o estímulo alvo (efeito atencional) no teste de atenção automática, o que não foi o caso. $\mathrm{O}$ efeito atencional automático foi bastante robusto $\mathrm{e}$ muito similar ao apresentado pelo GC. Ou seja, o estímulo precedente foi processado facilitando adequadamente o processamento do alvo. E caso $100 \mathrm{~ms}$ fosse um tempo curto para permitir a percepção visual na ausência de distrofina, os alvos de ambos os testes também não seriam percebidos, já que eles têm a mesma duração, o que levaria a um número de erros extremamente alto, principalmente de omissão, o que também não ocorreu. Assim, mesmo a sugestão inicial de que a falta de distrofina na retina poderia interferir na velocidade de processamento do alvo elevando os TR, poderia ser refutada. Isto porque além do estímulo precedente ter sido processado (evidenciado pelo efeito atencional automático robusto), na condição válida do teste de atenção voluntária, o TR do 
GD foi extremamente baixo, igual ao do GC. Estes dados reforçam a idéia do papel das alterações atencionais sobre os TR aumentados dos meninos com DMD.

Além disso, dados recentes parecem sugerir que o tempo de resposta motora a estímulos supralimiares, como é o nosso caso, não difere entre meninos com DMD e saudáveis. Em uma tarefa de detecção com TR simples, os TR foram similares entre os grupos (Zachi, 2008). Isto sugere que realmente haja alguma alteração de processamento envolvendo as demandas atencionais na DMD, e que isto é que estaria levando aos TR significativamente mais altos.

\subsection{Atenção voluntária}

Com relação ao teste de atenção voluntária, enquanto o GC apresentou um efeito atencional muito pequeno, o GD apresentou um efeito atencional enorme, evidenciado pelo custo e benefício extremamente altos e significativamente maiores que o GC. Nós acreditamos que o motivo desta grande diferença de efeitos entre os grupos segue um padrão de maturação atrasado do sistema atencional. Perche e Garcia-Larrea (2005) evidenciaram numa tarefa de atenção voluntária um efeito muito maior em um grupo de crianças de faixa etária menor do que a envolvida neste trabalho (6 a 9 anos) quando comparado a um grupo adulto jovem. Suportados também pelos exames de PRE, os autores sugerem que as crianças confiam mais na informação espacial dada pela pista para realizar a preparação de uma resposta. Isto significaria que as crianças apresentariam uma menor capacidade de manter uma alocação atencional em todo o campo visual; algo que um adulto realiza de forma eficiente, mesmo com um dos hemicampos tendo uma carga atencional determinada pelo estímulo. Alguns trabalhos, inclusive, revelaram haver uma mudança no padrão de reorientação e realocação da atenção entre 10-12 anos, quando já se assume um padrão similar ao dos adultos. Os autores relatam que mudanças no 
desenvolvimento sugerem maturação do sistema sensorial e/ou do processamento atencional, sendo que a alocação da atenção muda não só quantitativa, mas qualitativamente (Wetzel et al., 2006, Wetzel e Schröger, 2007).

Podemos transportar esta idéia para os nossos grupos de voluntários com média de idade já na adolescência (12 anos). O GC já se comportaria como o esperado, de maneira similar à dos adultos, confiando menos na informação espacial da pista, enquanto os meninos com DMD ainda estariam atrasados no desenvolvimento das capacidades atencionais, demonstrando um comportamento similar ao de crianças menores do que nove anos (Perche e Garcia-Larrea, 2005).

Já foi também observado em trabalhos anteriores um característico atraso no desenvolvimento de funções cognitivas (Billard et al, 1998, Cyrulnik et al, 2008) e no comportamento social (Hinton et al, 2006) dos meninos com DMD. A imaturidade do sistema atencional então seguiria este mesmo padrão. Sollee e colaboradores (1985) relatam um comprometimento atencional mais evidente em crianças mais jovens (com média de idade de 7 anos e 8 meses), quando comparadas com meninos com média de 13 anos e 3 meses. Os autores sugerem duas possibilidades para esta mudança no padrão das habilidades atencionais. Para eles, isso poderia decorrer de um fator sócio-ambiental, no qual crianças mais velhas, já cadeirantes, teriam mais condições de explorar e atender ao ambiente já que não haveria mais necessidade de grande gasto de energia para controle do equilíbrio durante a marcha; ou ainda, a outra possibilidade seria justamente o processo de maturação dos sistemas fronto-parietais de controle da atenção (Sollee et al, 1985). Nós verificamos uma correlação inversamente proporcional entre idade dos meninos com DMD e o efeito atencional voluntário, evidenciando que há uma diminuição do efeito atencional com a maior maturidade dos pacientes. Isso favorece ainda mais a idéia de um atraso na maturação do sistema atencional, sendo que com a idade, os meninos com DMD vão 
adquirindo um maior controle atencional, mais similar àquele apresentado por adultos jovens, e já evidente em crianças saudáveis com média de 12 anos de idade.

A imaturidade do sistema atencional voluntário pode ainda ser suportada pelo papel da distrofina e de suas isoformas truncadas no processo de maturação do SNC. Trabalhos que avaliaram a expressão da distrofina completa durante a embriogênese relatam que o aumento dramático da proteína presente em astrócitos e neurônios antes da décima quinta semana de gestação, a sua ausência em células gliais, e sua associação com a densidade pós-sináptica neuronal suportam a idéia de que a distrofina esteja envolvida com o processo de sinaptogênese e/ou de maturação das sinapses neuronais (Kim et al., 1992; Sogos et al, 2002), mais especificamente na maturação ou estabilização das sinapses GABAérgicas durante a embriogênese (Sekiguchi, 2005). Visto que os meninos que participaram do nosso estudo não apresentam comprometimento intelectual severo, uma alteração apenas a nível sináptico poderia favorecer a idéia de que a ausência de distrofina no desenvolvimento do SNC levaria ao atraso na aquisição do controle atencional.

Temos assim que o GD quando apenas orienta a atenção de maneira automática, sem a necessidade de um julgamento referente à probabilidade de ocorrência, apresenta um controle da atenção espacial adequado, similar ao do GC. Já quando há o envolvimento das funções executivas para a alocação da atenção, os meninos com DMD demonstraram comprometimento no gerenciamento dos recursos atencionais, interferindo na eficiência da alocação voluntária da atenção.

Resultados muito similares aos nossos foram também encontrados por Wilson e colaboradores (1997) ao avaliarem crianças com Desordem do Desenvolvimento de Coordenação (DDC) comparadas a crianças saudáveis. Crianças com DDC apresentaram TR nas condições mesma e oposta maiores que o GC, mas com efeito atencional similar; já na tarefa de atenção voluntária com pista simbólica central encontraram TR na condição 
válida igual entre os grupos, porém com TR na condição inválida maior no grupo DDC, o que gerou um efeito atencional muito maior neste grupo. Não foram utilizadas pistas neutras nos testes, o que levou à argumentação de que o aumento do TR apenas na condição inválida seria decorrente de um comprometimento exclusivamente no processo inibitório, de desengajamento, da atenção endógena, enquanto a orientação exógena da atenção se encontrava preservada. Esta análise pode estar apenas parcialmente correta, pois como foi visto em nosso trabalho, com a introdução da pista neutra, todo o processo atencional poderia estar comprometido. Em nosso trabalho, os dados demonstraram que o efeito atencional está aumentado tanto por um custo, como também por um benefício maior, evidenciando que não é só o processo inibitório que se encontra alterado, mas também há uma exacerbação dos processos facilitatórios, gerando assim uma confiança excessiva na pista simbólica por um processo de imaturidade do controle do sistema atencional voluntário.

Posteriormente foi verificado em tarefa diferente de atenção visual que esse processo de desengajamento lentificado em crianças com DDC é similar ao apresentado por crianças muito mais novas com desenvolvimento típico. No caso, o grupo com DDC cuja idade era de sete anos apresentava um padrão de performance na atenção visual similar ao de crianças de 3 e 4 anos de idade (Wilmut, Brown \& Wann, 2007). Isto sugere que um atraso na maturação do sistema atencional geraria padrões alterados de alocação voluntária da atenção, expressa pelo aumento do efeito atencional, evidenciado em crianças com DDC e agora, em crianças com DMD.

Podemos observar então que, na atenção voluntária, os meninos com DMD apresentam um comprometimento da atenção visuoespacial, enquanto a atenção temporal parece estar intacta devido ao maior tempo de processamento da pista e conseqüente preparação motora. 
Com relação à acurácia, não encontramos trabalhos com crianças que fizeram análise de erros de inversão, visto que o teste era em geral de TR de escolha simples, com a resposta dada com apenas uma das mãos, independentemente do local de aparecimento do alvo. Mas diversos trabalhos com crianças diagnosticadas com TDAH descrevem um número maior de erros de antecipação quando comparadas com crianças saudáveis, assim como alguns trabalhos também encontraram um maior número de erros de omissão (para revisão, veja Huang-Pollock \& Nigg, 2003). Wetzel e Schröger (2007) descrevem que crianças saudáveis mais jovens (6-8 anos) apresentam mais erros nos testes do que crianças mais velhas (10 a 12 anos) e adolescentes (não especificado tipo de erro). Estes dados parecem favorecer a idéia de imaturidade do sistema atencional nos meninos com DMD, que, como as crianças mais novas, também apresentaram mais erros, sendo que no nosso caso, foram erros de inversão.

Observamos ainda que apesar do GC ter apresentado TRs na condição válida menores que na condição inválida, essa diferença não foi significativa. Geralmente este teste gera um efeito atencional robusto, mesmo em adultos, e acreditamos que isto pode ser devido à baixa taxa de validade da pista no teste utilizado. Resolvemos utilizar uma taxa menor do que a descrita na literatura para que pudéssemos ter um número significativo de tentativas nas três condições, mesmo na presença de um número alto de erros (ambos os grupos apresentaram muitos voluntários com mais de 10\% de erros). Optamos por manter um número baixo de tentativas no teste (120 tentativas no total) para evitar que o teste ficasse extremamente longo e cansativo, evitando a falta de motivação e a fadiga muscular nos meninos com DMD. Porém, para possuirmos um número adequado de tentativas corretas nas três condições, formulamos o teste com $60 \%$ de tentativas válidas, $20 \%$ de tentativas neutras e $20 \%$ de tentativas inválidas. Excluindo-se as tentativas neutras, ainda mantivemos $75 \%$ das tentativas válidas e apenas $25 \%$ das tentativas inválidas, o que segue 
a validade da pista nos trabalhos sem presença da condição neutra. Contudo, esta relação talvez não tenha sido suficiente para o GC confiar e seguir totalmente a orientação da atenção à pista central; já o GD, mesmo com esta menor validade, adotou uma estratégia de seguir fortemente a orientação da pista, ao ponto de obter um benefício quase quatro vezes maior, porém ao custo de um prejuízo também enorme (mais de seis vezes maior que o GC). Outros autores também fizeram uso de proporcionalidade menor quando na presença de pistas neutras ao avaliarem pacientes (Pollux e Robertson, 2001).

Outra possibilidade que poderia ser pensada para a ausência de efeito atencional voluntário significativo do GC, inversa a esta apresentada anteriormente, seria uma dificuldade de adolescentes e pré-adolescentes saudáveis em controlarem a atenção voluntária, deixando-a menos eficiente. Esta idéia parece menos aceitável visto que alguns trabalhos demonstraram que crianças saudáveis com idade entre 6 e 9 anos já apresentam um efeito atencional significativo (Perchet e García-Larrea, 2000, 2005).

Assim, comparando os dois grupos, podemos observar que os pacientes com DMD apresentam uma função atencional alterada. $\mathrm{Na}$ presença de estímulos exógenos, há um comprometimento da preparação motora dada pela alteração do processamento temporal da pista, enquanto a orientação espacial da atenção se encontra preservada. Já na presença de estímulos endógenos, a atenção temporal está adequada, visto que há mais tempo para preparação à resposta ao alvo. Por outro lado a orientação espacial voluntária se mostra alterada, evidenciada pelo custo e benefício maiores no GD do que no GC, sugestivos de uma imaturidade do sistema atencional.

\subsection{Possíveis bases neurais das alterações atencionais observadas}

Para entendermos melhor os processos envolvidos na alteração atencional dos meninos com DMD, podemos tentar correlacionar as alterações já evidenciadas no SNC 
nesta patologia com os circuitos envolvidos no processo atencional de indivíduos saudáveis. As áreas descritas como ativas durante a orientação espacial da atenção são principalmente o córtex parietal posterior, ao redor do sulco intraparietal, o campo ocular frontal, lateral e medialmente ao córtex pré-motor, o giro cingulado, o tálamo e o colículo superior (Corbetta et al., 1993; Rosen et al., 1999; Kanwisher e Wojciulik, 2000; Corbetta e Shulman, 2002; Kincade et al., 2005). Além destas, o cerebelo tem sido descrito como tendo forte relação com as funções cognitivas além da função motora, com uma especial atuação sobre a função atencional (Daum et al., 1993; Allen et al., 1997; Townsend et al., 1999; Gottwald et al., 2003; Schoch et al., 2004).

Especificamente com relação às formas de orientação espacial da atenção avaliadas neste trabalho, Kincade et al. (2005) descrevem que existiriam algumas diferenças entre as áreas ativas durante a alocação voluntária e a alocação involuntária da atenção. A orientação voluntária da atenção produz uma maior ativação preparatória em áreas como o campo ocular frontal (COF, na junção dos sulcos frontal superior e pré-central) e o sulco intraparietal, regiões estas centrais para o controle do que eles denominam de rede frontoparietal dorsal. Já a junção têmporo-parietal, pertencente à chamada rede fronto-parietal ventral, juntamente com áreas occipitais e mesmo o COF da rede fronto-parietal dorsal, parecem estar mais ativas durante a orientação exógena da atenção espacial. Kim e colaboradores (1999) descrevem que diversas áreas são ativadas nos dois tipos de tarefa, porém a magnitude da ativação é maior na tarefa de orientação voluntária da atenção.

Já a atenção temporal envolve muitas áreas similares à atenção espacial, mas duas áreas estão mais ativas na atenção temporal: o sulco intraparietal esquerdo e o cerebelo esquerdo. O córtex pré-motor ventral esquerdo, na região genérica da área de Broca, também está ativo durante tarefa de atenção temporal (Coull e Nobre, 1998) 
Poderíamos pensar, então, numa relação possível entre algumas destas áreas, responsáveis pela geração de sinais atencionais, e os achados anatômicos e funcionais relacionados à concentração de distrofina no SNC saudável, e sua ausência em ratos mdx (Kamakura et al., 1994, Lidov et al., 1993) e em meninos com DMD (Uchino et al., 1996; para resumo, veja Anderson et al., 2002). Lidov et al. (1990) descrevem que a distrofina é abundante especialmente nos córtices cerebral e cerebelar, localizada na densidade da membrana pós-sináptica. Estudos com PET descrevem áreas específicas com hipometabolismo em meninos com DMD. Bresolin e colaboradores (1994) encontraram padrão variado de redução metábolica entre os pacientes estudados (estudos de casos isolados), com o cortex cerebelar bilateral e áreas de todas as regiões do córtex cerebral apresentando algum acometimento. Já trabalho mais controlado descreve que as áreas funcionalmente alteradas na DMD seriam as estruturas médio-temporais, córtex temporallateral direito, córtex sensoriomotor e cerebelo bilateral (Lee et al, 2002). Ambos os trabalhos sugerem que o cerebelo $\mathrm{e}$ as áreas corticais temporais poderiam estar relacionados ao comprometimento cognitivo, intelectual e comportamental evidenciados pelos pacientes. As alterações cerebelares, inclusive, parecem ter papel ainda mais relevante sobre os déficits cognitivos na DMD, seja pela sua própria função, ou pelas relações que estabelece com outras regiões corticais, principalmente frontais (Cyrulnik \& Hinton, 2008).

Com estes dados anátomo-funcionais, podemos fazer uma analogia com as alterações evidenciadas nos pacientes com DMD. Apesar de pouco se saber sobre as áreas possivelmente comprometidas na doença, algumas regiões como os córtices frontal, temporal e o cerebelo que estão hipofuncionantes na DMD são importantes na rede neural ligada à atenção tanto espacial como temporal. No caso, estas áreas poderiam apresentar 
um atraso no processo de maturação devido à falta de distrofina levando ao comprometimento da sua atuação no controle atencional (Felisari et al., 2000).

Como as alterações não foram observadas no teste de atenção automática, o atraso na maturação do SNC parece estar mais relacionado com as áreas responsáveis pelo controle voluntário da atenção. Diversos trabalhos sugerem que o córtex pré-frontal é determinante pro controle endógeno da atenção (Rosen et al, 1999; Corbetta \& Shulman, 2002; Kincade et al, 2005), cuja maturação só se completa por volta dos 18 anos (GómezPèrez et al, 2003; Kanemura et al, 2003; Tsujimoto, 2008) e, segundo Lidov et al. (2000), o cortex frontal é justamente uma área rica em distrofina nos cérebros saudáveis. Esse parece ser mais um dado sugestivo do papel que a deficiência de distrofina teria sobre o desenvolvimento cerebral e sua relação com o déficit cognitivo na DMD.

Coull e Nobre (1998) descrevem haver uma assimetria entre as formas de orientação da atenção. Enquanto a orientação temporal ativa áreas preferencialmente do hemisfério esquerdo, a atenção espacial apresenta uma lateralização com ativação preferencial do hemisfério direito. A atenção espacial teria maior foco no hemisfério direito, sendo que o hemisfério esquerdo direcionaria atenção predominantemente para o hemicampo direito, enquanto o hemisfério direito é ativado na orientação da atenção para os dois lados do espaço (Kim et al., 1999). Apesar de ter sido verificado que crianças com DMD apresentam uma ausência de assimetria/especialização hemisférica no repouso, durante a realização de tarefas elas evidenciaram uma ativação cortical assimétrica como esperada (Chiron et al, 1999). Nós também não encontramos diferenças na assimetria atencional nos meninos com DMD, nem durante o teste de atenção automática nem no teste de atenção voluntária, o que poderia sugerir que as alterações encontradas são mais globais, comprometendo a funcionalidade de ambos os hemisférios igualmente, e 
mantendo as assimetrias fisiológicas da atenção (Mesulam, 1999; Castro-Barros et al, 2008).

\subsection{Alterações atencionais e suas implicações na vida diária dos portadores de DMD.}

Problemas atencionais têm sido clinicamente descritos dentro do diagnóstico de Transtorno de Déficit de Atenção/ Hiperatividade (TDAH). Na DMD, apenas recentemente esta desordem psiquiátrica começou a ser investigada. Hendriksen \& Vles (2008) descreveram que, dentre os 351 meninos investigados através de questionário com os pais, 11,7\% apresentam diagnóstico médico de TDAH. Já Steele e colaboradores (2008) avaliaram diretamente a saúde mental de 10 meninos com DMD, sendo que metade deles foi então diagnosticado como possuindo TDAH. A incidência encontrada, ainda que em dados preliminares, é ainda mais alarmante. Como o trabalho de Hendriksen \& Vles (2008) foi feito por meio de questionário, a avaliação indireta permite que haja dados subestimados, além de haver critérios diagnósticos variados, como colocado pelos próprios autores. De qualquer modo, ambos os trabalhos apontam uma incidência muito maior do que a descrita para crianças em idade escolar (Schneider \& Eisenberg, 2006).

A TDAH é o distúrbio de maior impacto emocional, cognitivo e comportamental tratado na infância (Spencer, Biederman \& Mick, 2007), além de afetar também os componentes social e motor da criança (Poeta \& Rosa-Neto, 2007), possuindo um custo social significativamente alto e associado a um prejuízo importante na qualidade de vida das crianças (Hakkaart-van Roijen et al., 2007). Esta doença já foi amplamente estudada através dos testes de Posner de atenção encoberta visuoespacial (para revisão, veja HuangPollock \& Nigg, 2003) e, apesar da associação entre a DMD e a TDAH ainda ser pouco investigada, nossos dados contribuem para a idéia de haver um comprometimento 
significativo da atenção visuoespacial nos pacientes com DMD, cujo impacto social deve ser considerado.

O impacto funcional do comprometimento cognitivo na DMD também tem sido explorado. Hendriksen \& Vles (2006) observaram sério comprometimento do processamento seqüencial de informações entre os pacientes de 8 a 12 anos, sendo que 40\% deles apresentou déficit de leitura, com um coeficiente de $70 \%$ (índice muito baixo, indicativo de sérios problemas de leitura), sugerindo um alto risco de distúrbios de leitura nesta população. Marini e colabradores (2007) encontraram correlação positiva entre o comprometimento em alguns componentes de produção narrativa e déficits de atenção visuoespacial e de memória operacional. Os autores sugerem que a quantidade e a qualidade das descrições narrativas poderiam estar prejudicadas pelo comprometimento da acurácia na inspeção visual (Marini et al, 2007). Billard e col. (1998) não avaliaram diretamente a atenção, mas sugerem que o déficit no processamento fonológico observado por eles poderia ser decorrente de uma alteração atencional. Os autores encontraram comprometimento significativo nos componentes de leitura nos pacientes com DMD, sugerindo quadro similar à dislexia disfonética (Billard et al., 1998).

Assim, mesmo em pacientes cuja inteligência estaria normal, uma dificuldade de leitura e comprometimento no aprendizado declarativo poderia estar presente em grande parte dos meninos com DMD (Hinton et al, 2004). E os déficits de atenção parecem ser determinantes para esse quadro. Isso já foi observado na Distrofia Muscular de Becker (DMB), doença que acomete o mesmo gene da DMD, porém com quadro clínico em geral mais brando. Foi observado que, apesar do QI estar preservado na comparação com sujeitos normais, os meninos com DMB apresentaram uma alta freqüência de dificuldades de aprendizagem e uma significativa incidência de problemas atencionais $(36 \%$ dos sujeitos apresentou índice para diagnóstico de TDAH) (Young et al, 2008), o que sugere 
que mesmo entre aqueles com inteligência normal a atenção pode estar comprometida e interferir no desempenho escolar.

Torna-se então muito importante a avaliação neuropsicológica e do comportamento dos meninos com DMD, pois déficits de atenção podem permear mesmo aqueles com inteligência normal, e interferir no desempenho escolar e no desenvolvimento das habilidades de linguagem, da leitura e da escrita.

Uma das comorbidades mais freqüentes associadas à TDAH são as alterações na coordenação motora que pioram ainda mais a aprendizagem escolar e as atividades cotidianas destes pacientes. Foi observado que 55,2\% dos pacientes com TDAH apresentam Distúrbio do desenvolvimento da coordenação (DDC), sendo que principalmente os domínios de organização temporal, organização espacial e equilíbrio dos pacientes com TDAH estão piores do que os de crianças saudáveis. Inclusive a intervenção fisioterapêutica sobre essas crianças melhorou significativamente a performance motora. Acredita-se que seria o comprometimento na capacidade de manter a atenção que prejudicaria o controle da força e do movimento (Poeta \& Rosa-Neto, 2007, Watemberg et al, 2007). Assim, soma-se ainda um possível comprometimento central do controle do movimento, fator este muito agravante para o quadro de distrofia muscular, que já possui déficits motores de base. Os dados encontrados por Poeta \& Rosa-Neto (2007) vão ainda de encontro com os dados encontrados por nós, pois justamente os domínios de organização temporal e espacial estariam comprometidos e prejudicando o controle do movimento naqueles meninos com déficit primariamente de atenção dentro do grupo da TDAH.

Diversos trabalhos vêm mostrando o papel fundamental da atenção tanto sobre a aprendizagem de habilidades motoras (McNevin, Wulf \& Carlson, 2000; Wulf, McNevin, Shea, 2001) como nas correções necessárias durante a execução de movimentos 
(Boulinguez \& Nougier, 1999). Woollacott \& Shumway-Cook (2002) relatam uma série de experimentos que evidenciam a interferência da atenção nas atividades ditas automáticas, e sobre o controle da postura em pé e da marcha. A capacidade limitada de recursos neurais para processamento de informações compromete o desempenho de uma ou de duas atividades realizadas simultaneamente. As autoras demonstraram que, no caso dos idosos, os déficits no equilíbrio postural apresentados por eles seriam decorrentes não só da deterioração dos sistemas motores e sensoriais, mas também de déficits de alocação atencional. No caso, ao executarem uma tarefa de alta demanda cognitiva associada à necessidade de manter o equilíbrio em pé ou a marcha, a tarefa mais prejudicada é a motora, o que leva às típicas quedas apresentadas nessa faixa etária (Woollacott \& Shumway-Cook, 2002). Dados recentes evidenciaram o atraso nas aquisições de marcos motores nos meninos com Duchenne, incluindo a capacidade de engatinhar e andar, sendo que o atraso na marcha está relacionado ao comprometimento em demandas visuoespaciais (Cyrulnik et al., 2007). Não foram avaliados especificamente componentes atencionais, mas o atraso no desenvolvimento da atenção observado por nós poderia justificar, pelo menos em parte, o atraso no desenvolvimento de habilidades motoras descrito pelos autores. Além disso, o comprometimento acadêmico apresentado pelos meninos com DMD (Hinton et al., 2004) poderia ainda ser justificado pela dificuldade que teriam em alocar atenção em duas tarefas simultâneas, como atender ao professor e anotar as informações, já que, conforme observamos, eles depositam muita atenção para um local e têm um sério prejuízo ao alternarem o foco atencional para outro local. Assim, torna-se então essencial que outros trabalhos sejam realizados para verificar o impacto que esta imaturidade do sistema atencional dos meninos com DMD observada por nós teria tanto sobre componentes posturais e na marcha, como na leitura e desempenho escolar. E podemos pensar que não só o tratamento dos componentes motores deve ser considerado, mas 
também o cuidado aos aspectos atencionais poderiam atuar favorecendo a qualidade de vida desses pacientes. 


\section{CONCLUSÃO}

Os resultados deste trabalho nos permitem concluir que os meninos com DMD apresentam um prejuízo no controle do sistema atencional tanto temporal como espacial, respectivamente evidenciados por um déficit de preparação motora relacionada a pistas exógenas e pelo maior custo e benefício à pista endógena. 


\section{REFERÊNCIAS BIBLIOGRÁFICAS}

Allen G, Buxton RB, Wong EC, Courchesne E. Attentional activation of the cerebellum independent of motor involvement. Science. 1997; 275(5308):1940-3.

al-Qudah AA, Kobayashi J, Chuang S, Dennis M, Ray P. Etiology of intellectual impairment in Duchenne muscular dystrophy. Pedriatr Neurol. 1990; 6(1):57-59.

Anderson JL, Head SI, Rae C, Morley JW. Brain function in Duchenne muscular dystrophy. Brain. 2002; 125(Pt 1):4-13.

Anderson JL, Head SI, Morley JW. Long-term depression is reduced in cerebellar Purkinje cells of dystrophin-deficient mdx mice. Brain Res. 2004;1019(1-2):289-92.

Arrington CM, Carr TH, Mayer AR, Rao SM. Neural mechanisms of visual attention: object-based selection of a region in space. J Cogn Neurosci. 2000;12 Suppl 2:106-17.

Austin RC, Morris GE, Howard PL, Klamut HJ, Ray PN. Expression and synthesis of alternatively spliced variants of Dp71 in adult human brain. Neuromuscul Disord. 2000; 10(3):187-93.

Bach JR. Guia de exame e tratamento das doenças neuromusculares. São Paulo: Livraria e Editora Santos; 2004.

Bardoni A, Felisari G, Sironi M, Comi G, Lai M, Robotti M, Bresolin N. Loss of Dp140 regulatory sequences is associated with cognitive impairment in dystrophinopathies. Neuromuscul Disord. 2000; 10(3):194-9

Billard C, Gillet P, Signoret JL, Uicaut E, Bertrand P, Fardeau M, Barthez-Carpentier MA, Santini JJ. Cognitive functions in Duchenne muscular dystrophy: a reappraisal and comparison with spinal muscular atrophy. Neuromuscul Disord. 1992; 2(5-6):371-8.

Billard C, Gillet P, Barthez M, Hommet C, Bertrand P. Reading ability and processing in Duchenne muscular dystrophy and spinal muscular atrophy. Dev Med Child Neurol. 1998; 40(1):12-20.

Blake DJ, Kröger S. The neurobiology of Duchenne muscular dystrophy: learning from muscle? Trends Neurosci. 2000;23(3):92-99.

Boulinguez P, Nougier V. Control of goal-directed movements: the contribution of orienting of visual attention and motor preparation. Acta Psychol. 1999; 103(1-2):21-45. 
Bresolin N, Castelli E, Comi GP, Felisari G, Bardoni A, Perani D, Grassi F, Turconi A, Mazzucchelli F, Gallotti D, et al. Cognitive impairment in Duchenne muscular dystrophy. Neuromuscul Disord. 1994; 4(4):359-69.

Bushby KM. Genetic and clinical Correlations of Xp21 muscular dystrophy. J Inherit Metab Dis. 1992; 15(4):551-64.

Bushby KM, Appleton R, Anderson LV, Welch JL, Kelly P, Gardner-Medwin D. Deletion status and intellectual impairment in Duchenne muscular dystrophy. Dev Med Child Neurol. 1995; 37(3):260-9.

Casey BJ, Trainor R, Giedd J, Vauss Y, Vaituzis CK, Hamburger S, et al. The role of the anterior cingulate in automatic and controlled processes: a developmental neuroanatomical study. Dev Psychobiol. 1997; 30(1):61-9.

Castro-Barros BA, Righi LL, Grechi G, Ribeiro-do-Valle LE. Interlateral asymmetry in the time course of the effect of a peripheral prime stimulus. Brain Cogn. 2008 Apr;66(3):265-79.

Chiron C, Pinton F, Masure MC, Duvelleroy-Hommet C, Leon F, Billard C. Hemispheric specialization using SPECT and stimulation tasks in children with dysphasia and dystrophia. Dev Med Child Neurol. 1999; 41(8):512-20.

Corbetta M, Miezin FM, Shulman GL, Petersen SE. A PET study of visuospatial attention. J Neurosci. 1993;13(3):1202-26

Corbetta M, Shulman GL. Control of goal-directed and stimulus-driven attention in the brain. Nat Rev Neurosci. 2002; 3(3):201-15.

Costa MF, Oliveira AG, Feitosa-Santana C, Zatz M, Ventura DF. Red-green color vision impairment in Duchenne muscular dystrophy. Am J Hum Genet. 2007 Jun;80(6):1064-75.

Cotton S, Crowe SF, Voudouris N. Neuropsychological profile of Duchenne muscular dystrophy. Child Neuropsychol. 1998; 4(2):110-7.

Cotton S, Voudouris NJ, Greenwood KM. Intelligence and Duchenne muscular dystrophy: full scale, verbal, and performance intelligence quotients. Dev Med Child Neurol. 2001; 43(7):497-501. 
Cotton SM, Voudouris NJ, Greenwood KM. Association between intellectual functioning and age in children and young adults with Duchenne muscular dystrophy: further results from a meta-analysis. Dev Med Child Neurol. 2005; 47(4):257-65.

Coull JT. Neural correlates of attention and arousal: insights from electrophysiology, functional neuroimaging and psychopharmacology. Prog Neurobiol. 1998; 55(4):34361.

Coull JT, Nobre AC. Where and when to pay attention: the neural systems for directing attention to spatial locations and to time intervals as reveled by both PET and fMRI. J Neurosc. 1998; 18(18):7426-35.

Coull JT, Frith CD, Büchel C, Nobre AC. Orienting attention in time: behavioral and neuroanatomical distinction between exogenous and endogenous shifts. Neuropsychologia. 2000; 38(6):808-19.

Culligan K, Ohlendieck K. Diversity of the brain dystrophin-glycoprotein complex. J Biomed Biotechnol. 2002;2(1):31-36.

Cyrulnik SE, Fee RJ, De Vivo DC, Goldstein E, Hinton VJ. Delayed developmental language milestones in children with Duchenne's muscular dystrophy. J Pediatr. 2007; 150(5):474-8.

Cyrulnik SE, Hinton VJ. Duchenne muscular dystrophy: A cerebellar disorder? Neurosci Biobehav Rev. 2008; 32(3):486-96.

Cyrulnik SE, Fee RJ, Batchelder A, Kiefel J, Goldstein E, Hinton VJ. Cognitive and adaptive deficits in young children with Duchenne muscular dystrophy (DMD). J Int Neuropsychol Soc. 2008;14(5):853-61.

D'Mello GD, Steckler T. Animal models in cognitive behavioral pharmacology: an overview. Brain Res Cogn Brain Res. 1996; 3(3-4):345-52.

Daum I, Ackermann H, Schugens MM, Reimold C, Dichgans J, Birbaumer N. The cerebellum and cognitive functions in humans. Behav Neurosci. 1993; 107(3):411-9.

den Dunnen JT, Casula L, Makover A, et al. Mapping of dystrophin brain promoter: a deletion of this region is compatible with normal intellect. Neuromuscul Disord. 1991; $1: 327-331$ 
Dennis M, Edelstein K, Copeland K, Frederick J, Francis DJ, Hetherington R, Blaser SE, Kramer LA, Drake JM, Brandt ME, Fletcher JM. Covert orienting to exogenous and endogenous cues in children with spina bifida. Neuropsychologia. 2005; 43(6):976-87.

Di Lazzaro V, Restuccia D, Servidei S, Nardone R, Oliviero A, Profice P, Mangiola F, Tonali P, Rothwell JC. Functional involvement of cerebral cortex in Duchenne muscular dystrophy. Muscle Nerve. 1998; 21(5):662-4.

Dubowitz V, Crome L. The central nervous system in Duchenne muscular dystrophy. Brain. 1969; 92(4):805-8.

Emery AH. Population frequencies of inherited neuromuscular diseases - a world survey. Neuromuscul Disord. 1991; 1(1):19-29.

Felisari G, Martinelli Boneschi F, Bardoni A, Sironi M, Comi GP, Robotti M, Turconi AC, Lai M, Corrao G, Bresolin N. Loss of Dp140 dystrophin isoform and intellectual impairment in Duchenne dystrophy. Neurology. 2000; 55(4):559-64.

Figueiredo, VLM. Uma adaptação brasileira do teste de inteligência WISCIII. 230p. Tese de doutorado. Instituto de Psicologia, Universidade de Brasília, Brasília, 2001.

Gazzaniga MS. Atenção seletiva e Orientação. In: Gazzaniga MS, Ivry RB, Mangun GR, editors. Neurociência cognitiva. A biologia da mente. Porto Alegre: Artmed. 2006. p. 262-318.

Giliberto F, Ferreiro V, Dalamon V, Szijan I. Dystrophin deletions and cognitive impairment in Duchenne/Becker muscular dystrophy. Neurol Res. 2004; 26(1):83-7.

Girlanda P, Quartarone A, Buceti R, Sinicropi S, Macaione V, Saad FA, Messina L, Danieli GA, Ferreri G, Vita G. Extra-muscle involvement in dystrophinopathies: an electroretinography and evoked potential study. J Neurol Sci. 1997;146(2):127-32.

Goméz-Pérez E, Ostrosky-Solís F, Própero-García. Desarrollo de la atención, la memoria y los procesos inhibitorios: relación temporal con la maduración de la estructura y función cerebral. Revista de neurologia. 2003; 37(6), 561-7.

Gottwald B, Mihajlovic Z, Wilde B, Mehdorn HM. Does the cerebellum contribute to specific aspects of attention? Neuropsychologia. 2003; 41(11):1452-60.

Hackley SA, Valle-Inclán F. Which stages of processing are speeded by a warning signal? Biol Psychol. 2003; 64(1-2):27-45. 
Hackley SA, Schankin A, Wohlschlaeger A, Wascher E. Localization of temporal preparation effects via trisected reaction time. Psychophysiology. 2007; 44(2):334-8.

Hakkaart-van Roijen L, Zwirs BW, Bouwmans C, Tan SS, Schulpen TW, Vlasveld L, Buitelaar JK. Societal costs and quality of life of children suffering from attention deficient hyperactivity disorder (ADHD). Eur Child Adolesc Psychiatry. 2007; 16(5):316-26.

Helene AF, Xavier, GF. A construção da atenção a partir da memória. Revista Brasileira de Psiquiatria. 2003; 25 (Supl. II):12-20.

Hendriksen JGM, Vles JSH. Are males with Duchenne Muscular Dystrophy at risk for reading disabilities? Pediatr Neurol. 2006;34(4):296-300.

Hendriksen JG, Vles JS. Neuropsychiatric disorders in males with Duchenne muscular dystrophy: frequency rate of attention-deficit hyperactivity disorder (ADHD), autism spectrum disorder, and obsessive--compulsive disorder. $J$ Child Neurol. 2008;23(5):477-81.

Hinton VJ, De Vivo DC, Nereo NE. Poor verbal working memory across intellectual level in boys with Duchenne dystrophy. Neurology. 2000; 54(11):2127-32.

Hinton VJ, De Vivo DC, Nereo NE, Goldstein E, Stern Y. Selective deficits in verbal working memory associated with known genetic etiology: The neuropsychological profile of Duchenne muscular dystrophy. J Int Neuropsychol Soc. 2001; 7(1): 45-54.

Hinton VJ, De Vivo DC, Fee R, Goldstein E, Stern Y. Investigation of Poor Academic Achievement in Children with Duchenne Muscular Dystrophy. Learn Disabil Res Pract. 2004; 19(3):146-154.

Hinton VJ, Nereo NE, Fee RJ, Cyrulnik SE. Social behavior problems in boys with Duchenne muscular dystrophy. J Dev Behav Pediatr. 2006 Dec;27(6):470-6.

Hinton VJ, Fee RJ, Goldstein EM, De Vivo DC. Verbal and memory skills in males with Duchenne muscular dystrophy. Dev Med Child Neurol. 2007; 49(2):123-8.

Hodgson SV, Abbs S, Clark S, Manzur A, Heckmatt JZ, Dubowitz V, Bobrow M. Correlation of clinical and deletion data in Duchenne and Becker muscular dystrophy, with special reference to mental ability. Neuromuscul Disord. 1992;2(4):269-76. 
Huang-Pollock CL, Nigg JT. Searching for the attention deficit in attention deficit hyperactivity disorder: The case of visuoespatial orienting. Clin Psychol Rev. 2003; 23(6):801-30.

James W. The principles of psychology. Vol. 1. Dover publications, Nova Iorque, $1890 / 1950$

Jolas T, Zhang XS, Zhang Q, Wong G, Del Vecchio R, Gold L, Priestley T. Long-term potentiation is increased in the CA1 area of the hippocampus of APP (swe/ind) CRND8 mice. Neurobiol Dis. 2002; 11(3):394-409.

Jung D, Filliol D, Metz-Boutigue MH, Rendon A. Characterization and subcellular localization of the dystrophin-protein 71 (Dp71) from brain. Neuromuscul Disord. 1993; $3(5-6): 515-8$.

Kamakura K, Tadano Y, Kawai M, Ishiura S, Nakamura R, Miyamoto K, Sugita H. Dystrophin-related protein is found in the central nervous system of mice at various developmental stages, specially at the postsynaptic membrane. J Neurosci Res. 1994;37(6):728-34.

Kanemura H, Aihara M, Aoki S, Araki T, Nakazawa S. Development of the prefrontal lobe in infants and children: a three-dimensional magnetic resonance volumetric study. Brain Dev. 2003; 25(3):195-9.

Kanwisher N, Wojciulik E. Visual attention: insights from brain imaging. Nat Rev Neurosci. 2000;1(2):91-100.

Kato T, Nishina M, Matsushita K, Hori E, Akaboshi S, Takashima S. Increased cerebral choline-compounds in Duchenne muscular dystrophy. Neuroreport. 1997; 8(6):1435-7.

Kim TW, Wu K, Xu JL, Black IB. Detection of dystrophin in the postsynaptic density of rat brain and deficiency in a mouse model of Duchenne muscular dystrophy. Proc Natl Acad Sci U S A. 1992; 89(23):11642-4.

Kim TW, Wu K, Black IB. Deficiency of brain synaptic dystrophin in human Duchenne muscular dystrophy. Ann Neurol. 1995; 38(3):446-49.

Kim YH, Gitelman DR, Nobre AC, Parrish TB, LaBar KS, Mesulam MM. The largescale neural network for spatial attention displays multifunctional overlap but differential asymmetry. Neuroimage. 1999; 9(3):269-77. 
Kincade JM, Abrams RA, Astafiev SV, Shulman GL, Corbetta M. An event-related functional magnetic resonance imaging study of voluntary and stimulus-driven orienting of attention. J Neurosci. 2005; 25(18):4593-604.

Knudsen EI. Fundamental components of attention. Annu Rev Neurosci. 2007, 30:5778 .

Knuesel I, Mastrocola M, Zuellig RA, Bornhauser B, Schaub MC, Fritschy JM. Short communication: altered synaptic clustering of GABAA receptors in mice lacking dystrophin (mdx mice). Eur J Neurosci. 1999;11(12):4457-62.

Korkman M, Kemp SL, Kirk U. Effects of age on neurocognitive measures of children ages 5 to 12: a cross-sectional study on 800 children from the United States. Dev Neuropsychol. 2001;20(1):331-54.

Kueh SL, Head SI, Morley JW. GABA(A) receptor expression and inhibitory postsynaptic currents in cerebellar Purkinje cells in dystrophin-deficient mdx mice. Clin Exp Pharmacol Physiol. 2008;35(2):207-10.

LaBar KS, Gitelman DR, Parrish TB, Mesulan MM. Neuroanatomic overlap of working memory and spatial attention networks: A functional MRI comparison within subjects. Neuroimage. 1999; 10(6):695-704.

Lee JS, Pfund Z, Juhász C, Behen ME, Muzik O, Chugani DC, Nigro MA, Chugani HT. Altered regional brain metabolism in Duchenne Muscular Dystrophy: a PET study. Muscle Nerve. 2002; 26(4):506-12.

Lezak MD. Neuropsychological Assessment. Nova York: Oxford University Press; 1995.

Li ZH, Sun XW, Wang ZX, Zhang XC, Zhang DR, He S, Hu XP. Behavioral and functional MRI study of attention shift in human verbal working memory. Neuroimage. 2004; 21(1): 181-91.

Li Z, Bao M, Chen X, Zhang D, Han S, He S, Hu X. Attention shift in human verbal working memory: priming contribution and dynamic brain activation. Brain Res. 2006; 1078(1):131-42.

Lidov HG, Byers TJ, Watkins SC, Kunkel LM. Localization of dystrophin to postsynaptic regions of central nervous system cortical neurons. Nature. 1990; 348(6303):725-8. 
Lidov HG, Byers TJ, Kunkel LM. The distribution of dystrophin in the murine central nervous system: an immunocytochemical study. Neuroscience. 1993; 54(1):167-87.

Lidov HG, Selig S, Kunkel LM. Dp140: a novel $140 \mathrm{kDa}$ CNS transcript from the dystrophin locus. Hum Mol Genet. 1995; 4(3):329-35.

Lidov HG. The molecular neuropathology of the muscular dystrophies: a review and update. J Neuropathol Exp Neurol. 2000; 59(12):1019-30.

Lumeng CN, Hauser M, Brown V, Chamberlain JS. Expression of the $71 \mathrm{kDa}$ dystrophin isoform (Dp71) evaluated by gene targeting. Brain Res. 1999; 29;830(1):174-8.

Mandich A, Buckolz E, Polatajko H. Children with developmental coordination disorder (DCD) and their ability to disengage ongoing attentional focus: More on inhibitory function. Brain Cogn. 2003; 51(3):346-56.

Marini A, Lorusso ML, D'Angelo MG, Civati F, Turconi AC, Fabbro F, Bresolin N. Evaluation of narrative abilities in patients suffering from Duchenne Muscular Dystrophy. Brain Lang. 2007 Jul;102(1):1-12.

Marquez FG, Cisneros B, Garcia F, Ceja V, Velázquez F, Depardón F, Cervantes L, Rendón A, Mornet D, Rosas-vargas H, Mustre M, Montañez C. Differential expression and subcellular distribution of dystrophin Dp71 isoforms during differentiation process. Neuroscience. 2003;118(4):957-66.

McNevin NH, Wulf G, Carlson C. Effects of attentional focus, self-control, and dyad training on motor learning: implications for physical rehabilitation. Phys Ther. 2000; 80(4):373-85.

Mehler MF. Brain dystrophin, neurogenetics and mental retardation. Brain Res Brain Res Rev. 2000; 32(1):277-307.

Mesulam MM. Spatial attention and neglect: parietal, frontal and cingulate contributions to the mental representation and attentional targeting of salient extrapersonal events. Philos Trans R Soc Lond B Biol Sci. 1999; 354(1387):1325-46.

Miller J. A worning about median reaction time. J Exp Psychol Hum Percept Perform. 1988; 14(3):539-43. 
Moizard MP, Billard C, Toutain, A, Berret F, Marmin N, Moraine C. Are Dp71 and Dp140 brain dystrophin isoforms related to cognitive impairment in Duchenne muscular dystrophy? Am J Med Gen. 1998; 80(1): 32-41.

Moizard MP, Toutain A, Fournier D, Berret F, Raynaud M, Billard C, Andres C, Moraine C. Severe cognitive impairment in DMD: obvious clinical indication for Dp71 isoform point mutation screening. Eur J Hum Genet. 2000; 8(7): 552-6.

Morris GE, Simmons C, Nguyen TM. Apo-dystrophins (Dp140 and Dp71) and dystrophin splicing isoforms in developing brain. Biochem Biophys Res Commun. $1995 ; 215(1): 361-7$.

Muir JL. Attention and stimulus processing in the rat. Brain Res Cogn Brain Res. 1996; $3(3-4): 215-25$.

Muntoni F, Mateddu A, Serra G. Passive avoidance behaviour deficit in mdx mouse. Neuromuscul Disord. 1991; 1(2): 121-3

Muntoni F, Torelli S, Ferlini A. Dystrophin and mutations: one gene, several proteins, multiple phenotypes. Lancet Neurol. 2003; 2(12):731-40.

Nahas TR, Xavier GF. Atenção. In Andrade VM, Santos FH, Bueno OFA, editors. Neuropsicologia hoje. São Paulo, SP: Artes Médicas; 2004. p. 77-99.

Nicholson LV, Johnson MA, Bushby KMD, Gardner-Medwin D, Curtis A, Ginjaar IB, den Dunnen JT, Welch JL, Butler TJ, Bakker E, et al. Integrated study of 100 patients with Xp21 linked muscular dystrophy using clinical, genetic, immunochemical, and histopathological data. Part 2. Correlations within individual patients. J Med Genet. 1993; 30(9): 737-44.

Ogasawara A. Downward shift in IQ in persons with Duchenne muscular dystrophy compared to those with spinal muscular atrophy. Am J Ment Retard. 1989; 93(5): 544547.

Oldfield, RC. The assessment and analysis of handedness: the Edinburgh inventory. Neuropsychologia. 1971; 9(1):97-113. 
Pascual Pascual SI, Molano J, Pascual-Castroviejo I. Electroretinogram in Duchenne/Becker muscular dystrophy. Pediatr Neurol. 1998 Apr;18(4):315-20.

Perchet C, Garcia-Larrea L. Visuospatial attention and motor reaction in children: An electrophysiological study of the "Posner" paradigm. Psychophysiology. 2000; 37(2): 231-41.

Perchet C, Garcia-Larrea L. Learning to react: anticipatory mechanisms in children and adults during a visuospatial attention task. Clin Neurophysiol. 2005; 116(8): 1906-17.

Poeta LS, Rosa-Neto F. Motor assessment in school-aged children with indicators of the attention deficit/hyperactivity disorder. Rev Neurol. 2007; 1-15;44(3):146-9.

Polux PMJ, Robertson C. Voluntary and automatic visual spatial shifts of attention in Parkinson's Disease: An analysis of costs and benefits. J Clin Exp Neuropsychol. 2001: 23(5) 662-670.

Posner MI. Orienting of attention. Q J Exp Psychol. 1980: 32(1):3-25.

Poysky J; Behavior in DMD Study Group. Behavior patterns in Duchenne muscular dystrophy: report on the Parent Project Muscular Dystrophy behavior workshop 8-9 of December 2006, Philadelphia, USA. Neuromuscul Disord. 2007;17(11-12):986-94.

Rae C, Scott RB, Thompson CH, Dixon RM, Dumughn I, Kemp GJ, Male A, Pike M, Styles P, Radda GK. Brain biochemistry in Duchenne muscular dystrophy: a ${ }^{1} \mathrm{H}$ magnetic resonance and neuropsychological study. J Neurol Sci. 1998; 160(2):148-57

Rapaport D, Passos-Bueno MR, Brandão L, Love D, Vainzof M, Zatz M. Apparent association of mental retardation and specific patterns of deletions screened with probes Cf56a and Cf23a in Duchenne muscular dystrophy. Am J Med Genet. 1991; 39(4):43741

Ravizza SM, McCormick CA, Schlerf JE, Justus T, Ivry RB, Fiez JA. Cerebellar damage produces selective deficits in verbal working memory. Brain. 2006; 129 (Pt 2): 306-20.

Riggio L, Kirsner K. The relationship between central cues and peripheral cues in covert visual orientation. Percept Psychophys. 1997; 59(6):885-99.

Rosen AC, Rao SM, Caffarra P, Scaglioni A, Bobholz JA, Woodley SJ, Hammeke TA, Cunningham JM, Prieto TE, Binder JR. Neural basis of endogenous and exogenous spatial orienting. A functional MRI study. J Cogn Neurosci. 1999; 11(2):135-52. 
Sheliga BM, Riggio L, Rizzolatti G. Orienting of attention and eye movements. Exp Brain Res. 1994; 98(3):507-22.

Sheliga BM, Riggio L, Rizzolatti G. Spatial attention and eye movements. Exp Brain Res. 1995; 105(2):261-75.

Schmitz F, Drenckhahn D. Dystrophin in the retina. Prog Neurobiol. 1997; 53(5):54760 .

Schneider H, Eisenberg D. Who receives a diagnosis of attention-deficit/ hyperactivity disorder in the United States elementary school population? Pediatrics. 2006 Apr; 117(4):e601-9.

Schoch B, Gorissen B, Richter S, et al.. Do children with focal cerebellar lesions show deficits in shifting attention? J Neurophysiol. 2004; 92(3):1856-66.

Sekiguchi M. The role of dystrophin in the central nervous system: a mini review. Acta Myol. 2005; 24(2):93-7.

Sigesmund DA, Weleber RG, Pillers DA, et al. Characterization of the ocular phenotype of Duchenne and Becker muscular dystrophy. Ophthalmology. 1994; 101(5):856-65.

Sogos V, Curto M, Reali C, Gremo F. Developmentally regulated expression and localization of dystrophin and utrophin in the human fetal brain. Mech Ageing Dev. 2002; 123(5):455-62.

Sollee ND, Lathan EE, Kindlon DJ, Bresnan MJ. Neuropsychological impairment in Duchenne muscular dystrophy. J Clin Exp Neuropsychol. 1985; 7(5):486-96.

Spencer TJ, Biederman J, Mick E. Attention-deficit/hyperactivity disorder: diagnosis, lifespan, comorbidities, and neurobiology. J Pediatr Psychol. 2007 Jul;32(6):631-42.

Steele M, Taylor E, Young C, McGrath P, Lyttle BD, Davidson B. Mental health of children and adolescents with Duchenne muscular dystrophy. Dev Med Child Neurol. 2008;50(8):638-9.

Townsend J, Courchesne E, Covington J, Westerfield M, Harris NS, Lyden P, Lowry TP, Press GA. Spatial attention deficits in patients with acquired or developmental cerebellar abnormality. J Neurosci. 1999; 19(13):5632-43. 
Tracey I, Scott RB, Thompson CH, Dunn JF, Barnes PR, Styles P, Kemp GJ, Rae CD, Pike M, Radda GK. Brain abnormalities in Duchenne muscular dystrophy: prosphorus31 magnetic resonance spectroscopy and neuropsychological study. Lancet. 1995; 345(8960):1260-4.

Tsujimoto S. The prefrontal cortex: functional neural development during early childhood. Neuroscientist. 2008; 14(4):345-58.

Uchino M, Hara A, Mizuno Y, Fujiki M, Nakamura T, Tokunaga M, Hirano T, Yamashita T, Uyama E, Ando Y, Mita S, Ando M. Distribution of dystrophin and dystrophin-associated protein 43DAG (beta-dystroglycan) in the central nervous system of normal controls and patients with Duchenne muscular dystrophy. Intern Med. 1996;35(3):189-94.

Vaillend C, Rendon A, Misslin R, Ungerer A. Influence of dystrophin-gene mutation on mdx mouse behavior. Retention deficits at long delays in spontaneous alteration and bar-pressing tasks. Behavior Genetics. 1995; 25(6): 569-79.

Vaillend C, Billard JM. Facilitated CA1 hippocampal synaptic plasticity in dystrophindeficient mice: role for GABAA receptors? Hippocampus. 2002;12(6):713-7

Vaillend C, Billard JM, Laroche S. Impaired long-term spatial and recognition memory and enhanced CA1 hippocampal LTP in the dystrophin-deficient Dmd(mdx) mouse. Neurobiol Dis. 2004;17(1):10-20.

Watemberg N, Waiserberg N, Zuk L, Lerman-Sagie T. Developmental coordination disorder in children with attention-deficit-hyperactivity disorder and physical therapy intervention. Dev Med Child Neurol. 2007;49(12):920-5.

Wetzel N, Widmann A, Berti S, Schröger E. The development of involuntary and voluntary attention from childhood to adulthood: a combined behavioral and eventrelated potential study. Clin Neurophysiol. 2006; 117(10):2191-203.

Wetzel N, Schröger E. Cognitive control of involuntary attention and distraction in children and adolescents. Brain Res. 2007; 1155:134-46.

Whelan TB. Neuropsychological performance of children with Duchenne muscular dystrophy and spinal muscle atrophy. Dev Med Child Neurol. 1987; 29(2):212-20.

Wicksell RK, Kihlgren M, Melin L, Eeg-Olofsson O. Specific cognitive deficits are common in children with Duchenne muscular dystrophy. Dev Med Child Neurol. 2004; 46(3):154-9. 
Wijers AA, Been PH, Romkes KS. Dyslexics show a deviant lateralization on attentional control: a brain potential study. Neurosci Lett. 2005; 374(2):87-91.

Wilmut K, Brown JH, Wann JP. Attention disengagement in children with developmental coordination disorder. Disabil Rehabil. 2007; 29(1):47-55.

Wilson PH, Maruff P, McKenzie BE. Covert orienting of visuospatial attention in children with developmental coordination disorder. Dev Med Child Neurol. 1997;39(11):736-45.

Woollacott M, Shumway-Cook A. Attention and the control of posture and gait: a review of an emerging area of research. Gait Posture. 2002; 16(1):1-14.

Wulf G, McNevin N, Shea $\mathrm{CH}$. The automaticity of complex motor skill learning as a function of attentional focus. Q J Exp Psychol A. 2001; 54(4):1143-54.

Yaffe D, Makover A, Lederfein D, Rapaport D, Bar S, Barnea E, Nudel U. Multiple products of the Duchenne muscular dystrophy gene. Symp Soc Exp Biol. 1992; 46:17988 .

Yayla V, Oge AE, Deymeer F, Gurvit H, Akca-Kalem S, Parman Y, Oflazer P. Cortical excitability in Duchenne muscular dystrophy. Clin Neurophysiol. 2008; 119(2):459-65.

Young HK, Barton BA, Waisbren S, Portales Dale L, Ryan MM, Webster RI, North KN. Cognitive and psychological profile of males with Becker muscular dystrophy. J Child Neurol. 2008; 23(2):155-62.

Yoshioka M, Okuno T, Honda Y, Nakano Y. Central nervous system involvement in progressive muscular dystrophy. Arch Dis Child. 1980; 55(8): 589-94.

Zachi EC. Avaliação Neuropsciológica de pacientes com Distrofia Muscular de Duchenne. Tese apresentada para exame de qualificação pelo Programa de Neurociência e Comportamento, Instituto de Psicologia, USP. 2008. 


\section{ANEXOS}

\section{Anexo 1 - Questionário de Edinburg}

NOME

IDADE

Você já teve alguma tendência a ser canhoto?

Existe algum canhoto na sua família?

Indicar a preferência manual nas seguintes atividades, assinalando + na coluna apropriada, quando a preferência for tão forte de modo a você não ser capaz de usar a outra mão assinale ++ . Se não existir preferência, assinale + nas duas colunas.

\begin{tabular}{|l|l|l|}
\hline & DIREITA & ESQUERDA \\
\hline 1) Escrever & & \\
\hline 2) Desenhar & & \\
\hline 3) Jogar uma pedra & & \\
\hline 4) Usar uma tesoura & & \\
\hline 5) Usar um pente & & \\
\hline 6) Usar uma escova de dentes & & \\
\hline 7) Usar uma faca (sem o uso do garfo) & & \\
\hline 8) Usar uma colher & & \\
\hline 9) Usar um martelo & & \\
\hline 10) Usar uma chave de fendas & & \\
\hline 11) Usar uma raquete de tênis & & \\
\hline 12) Usar uma faca (com garfo) & & \\
\hline 13) Usar uma vassoura (mão superior) & & \\
\hline 14) Usar um ancinho (mão superior) & & \\
\hline 15) Acender um fósforo & & \\
\hline 16) Abrir um vidro com tampa(mão que segura a tampa) & & \\
\hline 17) Distribuir cartas & & \\
\hline 18) Enfiar a linha na agulha(mão que segura o que se move) & & \\
\hline 19) Com que pé você prefere chutar? & & \\
\hline
\end{tabular}

Total

QUOCIENTE DE LATERALIDADE

ACUIDADE VISUAL/ OD $\mathrm{OE}$ BIN 
Anexo 2 - Teste de acuidade visual

\begin{tabular}{|c|c|c|c|c|c|c|c|c|c|c|}
\hline \multicolumn{11}{|c|}{ TABELA DE LEITURA PARA PERTO } \\
\hline $0.37 \mathrm{~m}$ & & & 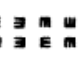 & & & $\begin{array}{ll}2 & 3 \\
6 & 4\end{array}$ & ${ }_{5}^{5}$ & & & J 1 \\
\hline $0.50 \mathrm{~m}$ & & E & $\begin{array}{lll}W & \Xi & \pi \\
E & m & \mu\end{array}$ & & $\begin{array}{l}3 \\
9\end{array}$ & & 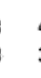 & $\begin{array}{l}9 \\
2\end{array}$ & & J 2 \\
\hline $0.62 \mathrm{~m}$ & & $\begin{array}{ll}\exists & E \\
E & E\end{array}$ & $\begin{array}{ll}\exists & \pi \\
m & \end{array}$ & $\begin{array}{l}\exists \\
E\end{array}$ & $\begin{array}{l}7 \\
6\end{array}$ & $\begin{array}{l}8 \\
9\end{array}$ & $\begin{array}{l}3 \\
7\end{array}$ & $\begin{array}{l}4 \\
5\end{array}$ & $\begin{array}{l}7 \\
2\end{array}$ & J 3 \\
\hline $0.75 \mathrm{~m}$ & $\begin{array}{l}\text { E } \\
\text { WI }\end{array}$ & $\begin{array}{l}\mathrm{w} \\
\mathrm{m}\end{array}$ & $\begin{array}{l}E \\
\mathbf{m}\end{array}$ & $\begin{array}{l}\mathrm{m} \\
\mathrm{E}\end{array}$ & $\begin{array}{l}8 \\
3\end{array}$ & $\begin{array}{l}5 \\
2\end{array}$ & & 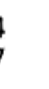 & $\begin{array}{l}9 \\
6\end{array}$ & J 4 \\
\hline $1.00 \mathrm{~m}$ & & $\begin{array}{l}\exists \\
E\end{array}$ & $\begin{array}{l}m \\
w\end{array}$ & $\begin{array}{l}\mathrm{E} \\
\mathrm{m}\end{array}$ & $\begin{array}{l}6 \\
1\end{array}$ & $\begin{array}{l}7 \\
8\end{array}$ & & $\begin{array}{l}2 \\
5\end{array}$ & $\begin{array}{l}6 \\
9\end{array}$ & J 5 \\
\hline $1.25 \mathrm{~m}$ & $\begin{array}{l}\mathbf{m} \\
\mathbf{m}\end{array}$ & $\begin{array}{l}\mathbf{E} \\
\Xi\end{array}$ & $\begin{array}{l}\boldsymbol{W} \\
\mathbf{E}\end{array}$ & $\begin{array}{l}\exists \\
\boldsymbol{\omega}\end{array}$ & $\begin{array}{l}8 \\
7\end{array}$ & & 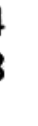 & $\begin{array}{l}6 \\
8\end{array}$ & $\begin{array}{l}2 \\
6\end{array}$ & J 6 \\
\hline
\end{tabular}




\section{Anexo 3 - Termo de Consentimento Livre e Esclarecido}

HOSPITAL DAS CLÍNICAS

DA

FACULDADE DE MEDICINA DA UNIVERSIDADE DE SÃO PAULO

TERMO DE CONSENTIMENTO LIVRE E ESCLARECIDO

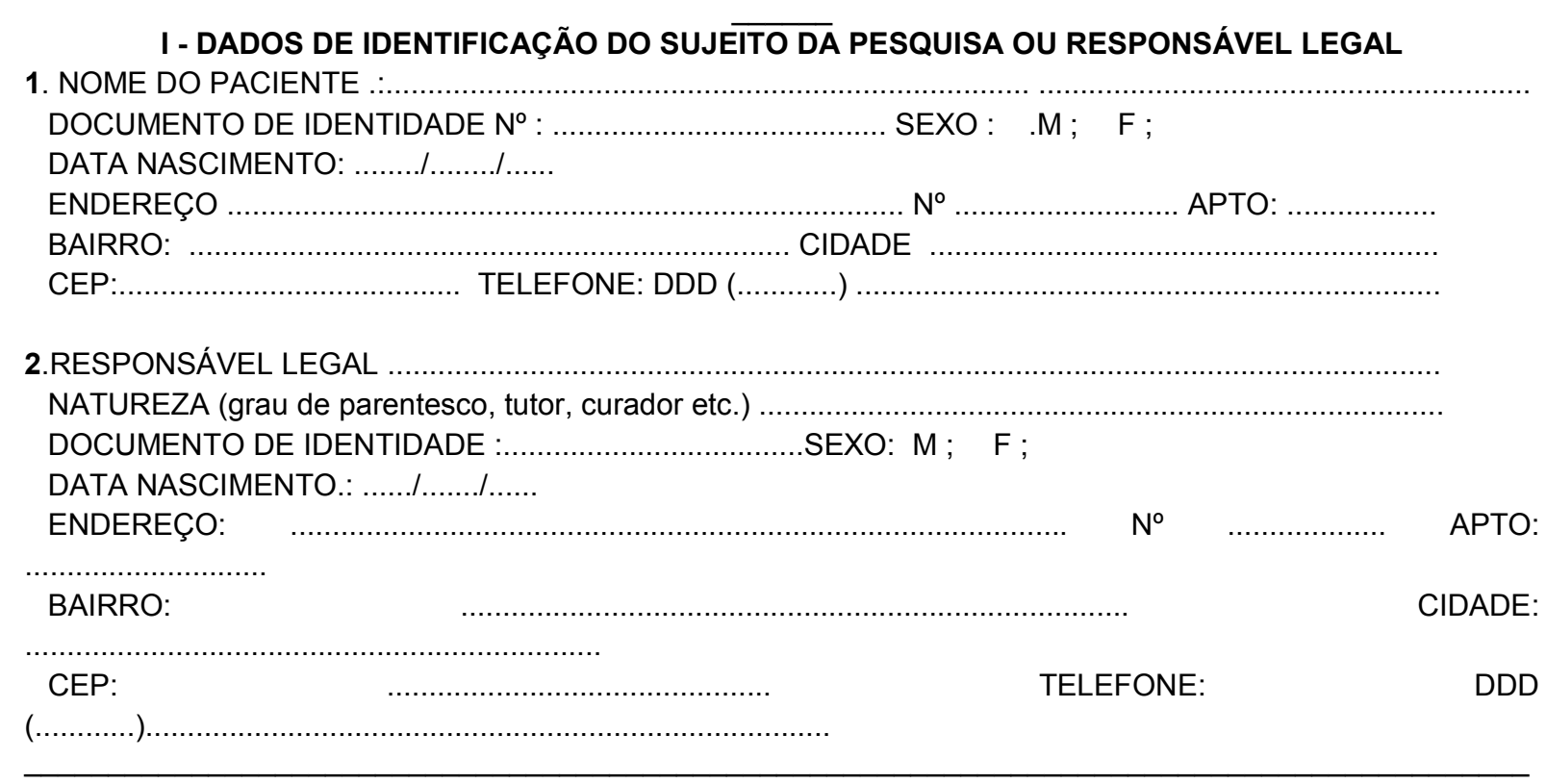

\section{II - DADOS SOBRE A PESQUISA CIENTÍFICA}

1. TÍTULO DO PROTOCOLO DE PESQUISA: Estudo do desempenho sensório-motor frente a estímulos visuais em Distrofia Muscular de Duchenne.

PESQUISADOR: Maria Clara Drummond Soares de Moura

CARGO/FUNÇÃO: Fisioterapeuta

INSCRIÇÃO CONSELHO REGIONAL No: 52371-F

UNIDADE DO HCFMUSP: Departamento de Neurologia Infantil

3. AVALIAÇÃO DO RISCO DA PESQUISA:

$\begin{array}{llll}\text { SEM RISCO } & \text { RISCO MÍNIMO } & X & \text { RISCO MÉDIO } \\ \text { RISCO BAIXO } & \text { RISCO MAIOR } \quad \square\end{array}$

(probabilidade de que o indivíduo sofra algum dano como consequência imediata ou tardia do estudo)

4.DURAÇÃO DA PESQUISA : 2 sessões de aproximadamente 1 hora com intervalo máximo de 7 dias entre elas

\section{III - REGISTRO DAS EXPLICAÇÕES DO PESQUISADOR AO PACIENTE OU SEU REPRESENTANTE LEGAL SOBRE A PESQUISA CONSIGNANDO:}

1. justificativa e os objetivos da pesquisa: Como alguns pacientes com Distrofia Muscular de Duchenne, apresentam distúrbios sensório-motores e desempenho prejudicado na escola, o objetivo deste trabalho é empregar diferentes testes, a serem realizadas em computador, e comparar o seu desempenho com crianças sem a doença com idade e sexo semelhantes.

2. procedimentos que serão utilizados e propósitos, incluindo a identificação dos procedimentos que são experimentais: Em uma sala escura, isolada de estímulos do ambiente, os pacientes deverão responder, apertando as teclas de um "mouse", quando aparecerem na tela do computador quatro tipos diferentes de estímulos visuais. Os quatro testes são simples, não envolvem qualquer risco ou perigo para o 
participante e serão aplicados em dois dias, sendo dois testes a cada dia, com intervalo máximo de uma semana entre eles. Cada sessão de testes terá duração de aproximadamente 45 minutos a uma hora, e haverá intervalos para descanso entre os testes.

3. desconfortos e riscos esperados: Os pacientes poderão apresentar leve cansaço físico durante os testes, podendo ser aumentado o tempo de descanso entre eles. Os testes em si não apresentarão risco algum.

4. benefícios que poderão ser obtidos: O conhecimento do tipo de déficit avaliado poderá auxiliar no relacionamento com os fisioterapeutas que explicam os tipos de exercícios usados na reabilitação e auxiliar os professores das escolas, assim como psicopedagogos, quando houver, a fim de melhorar o desempenho dos pacientes e o rendimento nas atividades escolares ou outras atividades intelectuias.

5. procedimentos alternativos que possam ser vantajosos para o indivíduo: Após a conclusão do estudo, as escolas serão contactadas para maiores esclarecimentos sobre os resultados, que ajudem a aplicar métodos de ensino adequados aos distúrbios avaliados de cada paciente. Quando o paciente mostrar nível normal, isso orientará os professores a terem as mesmas exigências, expectativas e formas de estímulo que têm com os alunos normais, embora, obviamente, levando em conta a limitação motora do paciente.

\section{IV - ESCLARECIMENTOS DADOS PELO PESQUISADOR SOBRE GARANTIAS DO SUJEITO DA PESQUISA CONSIGNANDO:}

1. acesso, a qualquer tempo, às informações sobre procedimentos, riscos e benefícios relacionados à pesquisa, inclusive para dirimir eventuais dúvidas.

Sim. O paciente ou seus familiares poderão contactar a Fisioterapeuta Maria Clara sempre que tiverem dúvidas ou precisarem de maiores esclarecimentos sobre os testes ou o trabalho em si.

2. liberdade de retirar seu consentimento a qualquer momento e de deixar de participar do estudo, sem que isto traga prejuízo à continuidade da assistência.

Sim. Se o paciente ou seus familiares quiserem interromper a participação no trabalho, poderão fazê-lo livremente e continuarão normalmente o seguimento médico.

3. salvaguarda da confidencialidade, sigilo e privacidade.

Os dados obtidos somente serão divulgados ao médico e à equipe de reabilitação que lida com o paciente, bem como aos professores da escola se os pais autorizarem.

4. disponibilidade de assistência no HCFMUSP, por eventuais danos à saúde, decorrentes da pesquisa.

Não há nenhum risco e o o atendimento médico no HC estará disponível da forma costumeira.

5. viabilidade de indenização por eventuais danos à saúde decorrentes da pesquisa.

Não há riscos ou danos.

\section{INFORMAÇÕES DE NOMES, ENDEREÇOS E TELEFONES DOS RESPONSÁVEIS PELO ACOMPANHAMENTO DA PESQUISA, PARA CONTATO EM CASO DE INTERCORRÊNCIAS CLÍNICAS E REAÇÕES ADVERSAS.}

Pesquisadora: Maria Clara Drummond Soares de Moura

Endereço: Instituto de Ciência Biomédicas/USP

Av. Prof. Lineu Prestes 1524, Sala 238. Cidade Universitária - São Paulo

Fone: 3091-7364/ 99507711

\section{VI - CONSENTIMENTO PÓS-ESCLARECIDO}

Declaro que, após convenientemente esclarecido pelo pesquisador e ter entendido o que me foi explicado, consinto em participar do presente Protocolo de Pesquisa

São Paulo, de de 2006.

assinatura do sujeito da pesquisa ou responsável legal

assinatura do pesquisador (carimbo ou nome Legível) 


\section{Anexo 4 - Descrição do Teste de Atenção Automática}

1. Você será testado em uma sala com iluminação reduzida de modo a reduzir interferências do ambiente.

2. Você vai realizar o teste sentado a frente de uma mesa sobre a qual apoiará seus braços.

3. Sua tarefa será manter sempre o olhar numa pequena cruz no centro da tela de um monitor de vídeo e pressionar, o mais rápido possível, uma tecla do mesmo lado em que aparecer uma linha vertical.

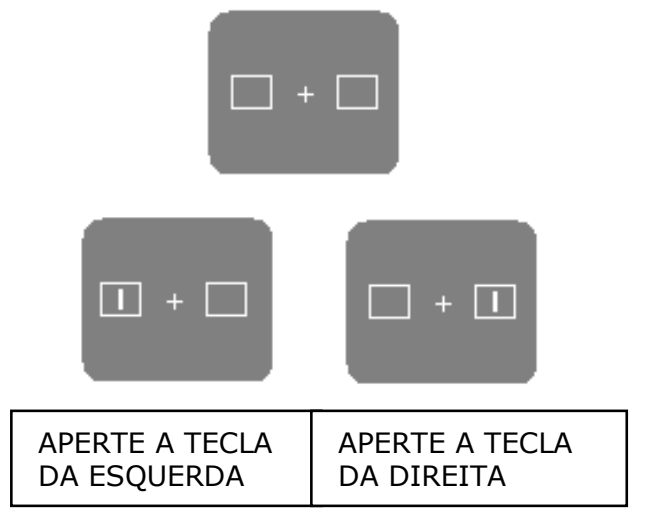

4. Ao fim de cada tentativa, uma mensagem aparecerá no centro da tela indicando se você acertou ou errou a tentativa. 


\section{Anexo 5 - Descrição do Teste de Atenção Voluntária}

1. Você será testado em uma sala com iluminação reduzida de modo a reduzir interferências do ambiente.

2. Você vai realizar o teste sentadoa frente de uma mesa sobre a qual apoiará os braços.

3. Sua tarefa será manter sempre o olhar numa pequena cruz no centro da tela de um monitor de vídeo.

4. A seguir aparecerá no centro da tela uma seta voltada para a direita ou para a esquerda e você deverá direcionar sua atenção para o lado indicado na seta, sem mover os olhos do centro da tela. Poderá ainda aparecer duas setas ao mesmo tempo, quando você deverá manter sua atenção difusa.
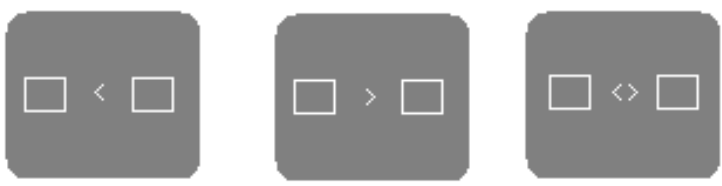

5. A seguir, você deverá pressionar, o mais rápido possível, uma tecla do mesmo lado em que aparecer uma linha vertical.

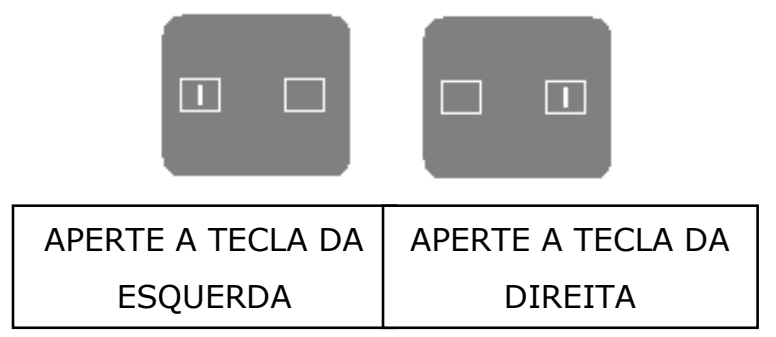

9. Ao fim de cada tentativa, uma mensagem aparecerá no centro da tela indicando se você acertou ou errou a tentativa. 


\section{Anexo 6 - Tabelas de dados}

Tabela 6.1. Tempos de reação no teste de atenção automática para o Grupo controle (GC) e Grupo Duchenne (GD).

\begin{tabular}{ccccccc} 
Tempo de Reação & \multicolumn{3}{c}{ Controle (GC) } & \multicolumn{3}{c}{ Duchenne (GD) } \\
\hline $\begin{array}{c}\text { Atenção } \\
\text { Automática }\end{array}$ & Mesma & Oposta & Bilateral & Mesma & Oposta & Bilateral \\
\hline 1 & 299 & 363 & 327 & 383 & 487 & 433 \\
2 & 271 & 346 & 334 & 348 & 430 & 333 \\
3 & 291 & 404 & 339 & 383 & 472 & 408 \\
4 & 260 & 312 & 277 & 275 & 324 & 293 \\
5 & 370 & 392 & 353 & 574 & 623 & 557 \\
6 & 376 & 402 & 351 & 586 & 591 & 548 \\
7 & 273 & 336 & 290 & 275 & 338 & 309 \\
8 & 245 & 312 & 296 & 509 & 463 & 509 \\
9 & 231 & 322 & 268 & 308 & 401 & 349 \\
10 & 257 & 333 & 289 & 247 & 325 & 266 \\
11 & 377 & 420 & 361 & 440 & 452 & 402 \\
12 & 265 & 334 & 292 & 369 & 424 & 381 \\
13 & 392 & 425 & 354 & 361 & 434 & 387 \\
14 & 336 & 374 & 331 & 425 & 439 & 438 \\
15 & 363 & 457 & 396 & 309 & 409 & 352 \\
16 & 276 & 342 & 318 & 333 & 381 & 357 \\
17 & 452 & 473 & 431 & 252 & 332 & 292 \\
18 & 282 & 338 & 301 & 467 & 530 & 439 \\
19 & 245 & 339 & 293 & 271 & 360 & 319 \\
20 & 239 & 279 & 258 & 309 & 386 & 324 \\
21 & 332 & 373 & 313 & 354 & 437 & 390 \\
22 & 403 & 433 & 417 & 344 & 408 & 393 \\
23 & 313 & 387 & 320 & 447 & 452 & 470 \\
24 & 367 & 409 & 397 & 340 & 442 & 410 \\
25 & 288 & 331 & 307 & 365 & 434 & 370 \\
\hline Média & $\mathbf{3 1 2}$ & $\mathbf{3 6 9}$ & $\mathbf{3 2 8}$ & $\mathbf{3 7 1}$ & $\mathbf{4 3 1}$ & $\mathbf{3 8 9}$ \\
E.p.m. & $\mathbf{1 2}$ & $\mathbf{1 0}$ & $\mathbf{9}$ & $\mathbf{1 8}$ & $\mathbf{1 5}$ & $\mathbf{1 5}$ \\
\hline & & & & & &
\end{tabular}


Tabela 6.2. Tempos de reação no teste de atenção voluntária para o Grupo controle (GC) e Grupo Duchenne (GD).

\begin{tabular}{|c|c|c|c|c|c|c|}
\hline Tempo de Reação & \multicolumn{3}{|c|}{ Controle (GC) } & \multicolumn{3}{|c|}{ Duchenne (GD) } \\
\hline $\begin{array}{c}\text { Atenção } \\
\text { Voluntária }\end{array}$ & Válida & Inválida & Neutra & Válida & Inválida & Neutra \\
\hline 1 & 301 & 304 & 312 & 300 & 405 & 355 \\
\hline 2 & 290 & 351 & 350 & 259 & 476 & 279 \\
\hline 3 & 344 & 373 & 329 & 301 & 432 & 361 \\
\hline 4 & 262 & 281 & 277 & 251 & 276 & 270 \\
\hline 5 & 363 & 344 & 312 & 383 & 445 & 426 \\
\hline 6 & 356 & 401 & 388 & 436 & 574 & 521 \\
\hline 7 & 302 & 309 & 323 & 294 & 356 & 359 \\
\hline 8 & 264 & 268 & 263 & 490 & 562 & 486 \\
\hline 9 & 295 & 252 & 284 & 301 & 339 & 359 \\
\hline 10 & 401 & 393 & 376 & 240 & 300 & 265 \\
\hline 11 & 362 & 410 & 404 & 405 & 499 & 473 \\
\hline 12 & 288 & 323 & 311 & 301 & 438 & 373 \\
\hline 13 & 295 & 368 & 360 & 356 & 438 & 378 \\
\hline 14 & 337 & 354 & 370 & 342 & 572 & 363 \\
\hline 15 & 350 & 320 & 324 & 298 & 332 & 304 \\
\hline 16 & 273 & 313 & 297 & 335 & 352 & 336 \\
\hline 17 & 378 & 417 & 425 & 233 & 233 & 246 \\
\hline 18 & 308 & 310 & 310 & 371 & 400 & 377 \\
\hline 19 & 309 & 296 & 279 & 291 & 403 & 325 \\
\hline 20 & 253 & 272 & 246 & 311 & 326 & 345 \\
\hline 21 & 319 & 356 & 394 & 404 & 441 & 465 \\
\hline 22 & 320 & 353 & 320 & 289 & 309 & 314 \\
\hline 23 & 315 & 348 & 332 & 336 & 477 & 394 \\
\hline 24 & 382 & 363 & 320 & 346 & 386 & 376 \\
\hline 25 & 241 & 287 & 273 & 261 & 385 & 312 \\
\hline Média & 316 & 334 & 327 & 325 & 406 & 362 \\
\hline E.p.m. & 9 & 9 & 9 & 13 & 18 & 14 \\
\hline
\end{tabular}


Tabela 6.3. Efeitos atenção automática (benefício, custo e efeito atencional total) para o Grupo controle (GC) e Grupo Duchenne (GD).

\begin{tabular}{|c|c|c|c|c|c|c|}
\hline \multirow{2}{*}{$\begin{array}{c}\text { Efeito da Atenção } \\
\text { Automática } \\
\end{array}$} & \multicolumn{3}{|c|}{ Controle (GC) } & \multicolumn{3}{|c|}{ Duchenne (GD) } \\
\hline & Benefício & Custo & Efeito & Benefício & Custo & Efeito \\
\hline 1 & 28 & 36 & 64 & 50 & 54 & 104 \\
\hline 2 & 63 & 12 & 75 & -15 & 97 & 82 \\
\hline 3 & 49 & 65 & 114 & 26 & 64 & 89 \\
\hline 4 & 17 & 35 & 52 & 18 & 31 & 49 \\
\hline 5 & -17 & 39 & 22 & -17 & 66 & 49 \\
\hline 6 & -25 & 52 & 26 & -39 & 43 & 4 \\
\hline 7 & 18 & 46 & 63 & 34 & 29 & 63 \\
\hline 8 & 52 & 16 & 68 & 0 & -46 & -46 \\
\hline 9 & 38 & 54 & 92 & 41 & 52 & 93 \\
\hline 10 & 32 & 44 & 76 & 20 & 59 & 78 \\
\hline 11 & -16 & 59 & 43 & -37 & 50 & 13 \\
\hline 12 & 27 & 42 & 69 & 12 & 43 & 55 \\
\hline 13 & -38 & 71 & 33 & 26 & 47 & 73 \\
\hline 14 & -5 & 43 & 38 & 13 & 1 & 14 \\
\hline 15 & 33 & 61 & 94 & 43 & 57 & 100 \\
\hline 16 & 42 & 25 & 67 & 24 & 24 & 48 \\
\hline 17 & -21 & 42 & 22 & 39 & 41 & 80 \\
\hline 18 & 19 & 38 & 57 & -28 & 91 & 63 \\
\hline 19 & 48 & 46 & 94 & 49 & 41 & 89 \\
\hline 20 & 20 & 21 & 41 & 15 & 62 & 76 \\
\hline 21 & -20 & 61 & 41 & 36 & 47 & 83 \\
\hline 22 & 14 & 16 & 30 & 49 & 15 & 64 \\
\hline 23 & 7 & 67 & 74 & 23 & -18 & 5 \\
\hline 24 & 30 & 12 & 42 & 70 & 32 & 102 \\
\hline 25 & 18 & 24 & 42 & 5 & 64 & 69 \\
\hline Média & 16 & 41 & 57 & 18 & 42 & 60 \\
\hline E.p.m. & 5 & 4 & 5 & 6 & 6 & 7 \\
\hline
\end{tabular}


Tabela 6.4. Efeitos atenção voluntária (benefício, custo e efeito atencional total) para o Grupo controle (GC) e Grupo Duchenne (GD).

\begin{tabular}{|c|c|c|c|c|c|c|}
\hline \multirow{2}{*}{$\begin{array}{c}\text { Efeito da Atenção } \\
\text { Voluntária }\end{array}$} & \multicolumn{3}{|c|}{ Controle (GC) } & \multicolumn{3}{|c|}{ Duchenne (GD) } \\
\hline & Benefício & Custo & Efeito & Benefício & Custo & Efeito \\
\hline 1 & 11 & -8 & 3 & 55 & 50 & 105 \\
\hline 2 & 61 & 1 & 61 & 21 & 197 & 217 \\
\hline 3 & -15 & 43 & 29 & 60 & 71 & 132 \\
\hline 4 & 15 & 4 & 19 & 19 & 6 & 25 \\
\hline 5 & -51 & 32 & -19 & 44 & 19 & 62 \\
\hline 6 & 32 & 13 & 45 & 85 & 53 & 138 \\
\hline 7 & 21 & -14 & 7 & 66 & -3 & 62 \\
\hline 8 & -1 & 5 & 4 & -4 & 76 & 72 \\
\hline 9 & -11 & -32 & -43 & 58 & -20 & 38 \\
\hline 10 & -26 & 17 & -9 & 25 & 35 & 59 \\
\hline 11 & 42 & 6 & 48 & 68 & 27 & 95 \\
\hline 12 & 24 & 12 & 35 & 72 & 64 & 137 \\
\hline 13 & 66 & 8 & 73 & 21 & 61 & 82 \\
\hline 14 & 34 & -17 & 17 & 21 & 208 & 229 \\
\hline 15 & -26 & -5 & -30 & 6 & 28 & 34 \\
\hline 16 & 24 & 16 & 40 & 0 & 17 & 17 \\
\hline 17 & 47 & -8 & 39 & 13 & -13 & 0 \\
\hline 18 & 2 & 0 & 2 & 6 & 23 & 29 \\
\hline 19 & -30 & 17 & -14 & 34 & 78 & 112 \\
\hline 20 & -7 & 26 & 19 & 34 & -19 & 15 \\
\hline 21 & 75 & -37 & 38 & 61 & -24 & 37 \\
\hline 22 & 0 & 33 & 33 & 25 & -5 & 20 \\
\hline 23 & 17 & 17 & 33 & 58 & 83 & 141 \\
\hline 24 & -62 & 43 & -19 & 31 & 10 & 41 \\
\hline 25 & 32 & 14 & 46 & 52 & 73 & 125 \\
\hline Média & 11 & 7 & 18 & 37 & 44 & 81 \\
\hline E.p.m. & 7 & 4 & 6 & 5 & 12 & 12 \\
\hline
\end{tabular}


Tabela 6.5. Erros de antecipação nos testes de atenção automática e atenção voluntária para o Grupo controle (GC) e Grupo Duchenne (GD).

\begin{tabular}{|c|c|c|c|c|}
\hline \multirow{2}{*}{$\begin{array}{c}\text { Erros de } \\
\text { antecipação }\end{array}$} & \multicolumn{2}{|c|}{ Atenção Automática } & \multicolumn{2}{|c|}{ Atenção Voluntária } \\
\hline & Controle (GC) & $\begin{array}{c}\text { Duchenne } \\
\text { (GD) }\end{array}$ & $\begin{array}{c}\begin{array}{c}\text { Controle } \\
\text { (GC) }\end{array} \\
\end{array}$ & $\begin{array}{c}\text { Duchenne } \\
\text { (GD) }\end{array}$ \\
\hline 1 & 1 & 2 & 3 & 2 \\
\hline 2 & 8 & 7 & 5 & 15 \\
\hline 3 & 3 & 1 & 0 & 16 \\
\hline 4 & 2 & 1 & 2 & 1 \\
\hline 5 & 3 & 0 & 3 & 2 \\
\hline 6 & 1 & 0 & 8 & 5 \\
\hline 7 & 0 & 7 & 0 & 2 \\
\hline 8 & 15 & 10 & 2 & 11 \\
\hline 9 & 9 & 2 & 8 & 6 \\
\hline 10 & 4 & 16 & 0 & 4 \\
\hline 11 & 2 & 1 & 7 & 9 \\
\hline 12 & 5 & 0 & 8 & 2 \\
\hline 13 & 1 & 0 & 6 & 3 \\
\hline 14 & 1 & 0 & 2 & 7 \\
\hline 15 & 0 & 0 & 4 & 1 \\
\hline 16 & 4 & 2 & 3 & 2 \\
\hline 17 & 3 & 3 & 5 & 5 \\
\hline 18 & 1 & 1 & 2 & 2 \\
\hline 19 & 0 & 8 & 3 & 7 \\
\hline 20 & 5 & 1 & 4 & 1 \\
\hline 21 & 1 & 5 & 3 & 6 \\
\hline 22 & 2 & 0 & 9 & 2 \\
\hline 23 & 3 & 4 & 4 & 15 \\
\hline 24 & 1 & 3 & 9 & 3 \\
\hline 25 & 0 & 0 & 2 & 3 \\
\hline Total & 75 & 74 & 102 & 132 \\
\hline Média & 3 & 2,96 & 4,08 & 5,28 \\
\hline E.p.m. & 0,69 & 0,79 & 0,56 & 0,92 \\
\hline
\end{tabular}


Tabela 6.6. Erros de omissão nos testes de atenção automática e atenção voluntária para o Grupo controle (GC) e Grupo Duchenne (GD).

\begin{tabular}{|c|c|c|c|c|}
\hline \multirow{2}{*}{$\begin{array}{l}\text { Erros de } \\
\text { omissão }\end{array}$} & \multicolumn{2}{|c|}{ Atenção Automática } & \multicolumn{2}{|c|}{ Atenção Voluntária } \\
\hline & $\begin{array}{c}\text { Controle } \\
\text { (GC) }\end{array}$ & Duchenne (GD) & Controle (GC) & Duchenne (GD) \\
\hline 1 & 0 & 1 & 0 & 0 \\
\hline 2 & 1 & 2 & 0 & 1 \\
\hline 3 & 0 & 0 & 2 & 2 \\
\hline 4 & 1 & 0 & 0 & 0 \\
\hline 5 & 1 & 1 & 1 & 0 \\
\hline 6 & 1 & 4 & 2 & 2 \\
\hline 7 & 0 & 0 & 0 & 1 \\
\hline 8 & 0 & 0 & 1 & 3 \\
\hline 9 & 0 & 2 & 0 & 0 \\
\hline 10 & 1 & 0 & 1 & 0 \\
\hline 11 & 0 & 1 & 4 & 10 \\
\hline 12 & 0 & 0 & 0 & 1 \\
\hline 13 & 1 & 1 & 0 & 1 \\
\hline 14 & 2 & 0 & 1 & 2 \\
\hline 15 & 0 & 0 & 1 & 0 \\
\hline 16 & 0 & 3 & 0 & 1 \\
\hline 17 & 1 & 1 & 0 & 0 \\
\hline 18 & 1 & 0 & 2 & 4 \\
\hline 19 & 2 & 6 & 0 & 0 \\
\hline 20 & 0 & 0 & 0 & 0 \\
\hline 21 & 1 & 0 & 1 & 1 \\
\hline 22 & 0 & 2 & 0 & 0 \\
\hline 23 & 1 & 1 & 4 & 3 \\
\hline 24 & 0 & 0 & 0 & 0 \\
\hline 25 & 0 & 0 & 0 & 2 \\
\hline Total & 14 & 25 & 20 & 34 \\
\hline Média & 0,56 & 1 & 0,8 & 1,36 \\
\hline E.p.m. & 0,13 & 0,3 & 0,24 & 0,43 \\
\hline
\end{tabular}


Tabela 6.7. Erros de inversão no teste de atenção automática para o Grupo controle (GC) e Grupo Duchenne (GD).

Erros de inversão Controle (GC)

Duchenne (GD)

Atenção Automática

Mesma Oposta Bilateral Total Mesma Oposta Bilateral Total

\begin{tabular}{|c|c|c|c|c|c|c|c|c|}
\hline 1 & 1 & 2 & 1 & 4 & 2 & 2 & 1 & 5 \\
\hline 2 & 1 & 4 & 1 & 6 & 1 & 2 & 1 & 4 \\
\hline 3 & 1 & 5 & 0 & 6 & 1 & 4 & 1 & 6 \\
\hline 4 & 0 & 3 & 0 & 3 & 0 & 0 & 0 & $\mathbf{0}$ \\
\hline 5 & 5 & 6 & 1 & 12 & 0 & 1 & 0 & 1 \\
\hline 6 & 0 & 1 & 0 & 1 & 0 & 1 & 1 & 2 \\
\hline 7 & 0 & 3 & 1 & 4 & 0 & 6 & 1 & 7 \\
\hline 8 & 0 & 4 & 3 & 7 & 0 & 3 & 1 & 4 \\
\hline 9 & 0 & 2 & 2 & 4 & 0 & 2 & 0 & 2 \\
\hline 10 & 0 & 4 & 0 & 4 & 0 & 9 & 2 & 11 \\
\hline 11 & 0 & 2 & 1 & 3 & 3 & 2 & 4 & 9 \\
\hline 12 & 0 & 3 & 1 & 4 & 2 & 2 & 1 & 5 \\
\hline 13 & 0 & 2 & 3 & 5 & 0 & 0 & 0 & 0 \\
\hline 14 & 3 & 6 & 7 & 16 & 2 & 3 & 2 & 7 \\
\hline 15 & 0 & 0 & 2 & 2 & 3 & 5 & 2 & 10 \\
\hline 16 & 0 & 2 & 2 & 4 & 0 & 2 & 0 & 2 \\
\hline 17 & 2 & 0 & 0 & 2 & 0 & 4 & 1 & 5 \\
\hline 18 & 0 & 2 & 2 & 4 & 0 & 3 & 0 & 3 \\
\hline 19 & 0 & 5 & 0 & 5 & 0 & 3 & 1 & 4 \\
\hline 20 & 0 & 0 & 0 & 0 & 0 & 3 & 0 & 3 \\
\hline 21 & 1 & 5 & 3 & 9 & 3 & 1 & 1 & 5 \\
\hline 22 & 1 & 0 & 0 & 1 & 0 & 2 & 1 & 3 \\
\hline 23 & 3 & 4 & 1 & 8 & 0 & 3 & 2 & 5 \\
\hline 24 & 0 & 0 & 0 & $\mathbf{0}$ & 0 & 3 & 0 & 3 \\
\hline 25 & 0 & 2 & 1 & 3 & 0 & 5 & 1 & 6 \\
\hline Total & 18 & 67 & 32 & 117 & 17 & 71 & 24 & 112 \\
\hline Média & 0,72 & 2,68 & 1,28 & 4,68 & 0,68 & 2,84 & 0,96 & 4,48 \\
\hline E.p.m. & 0,26 & 0,38 & 0,31 & $\mathbf{0 , 7 3}$ & 0,22 & 0,39 & 0,19 & $\mathbf{0 , 5 7}$ \\
\hline
\end{tabular}


Tabela 6.8. Erros de inversão no teste de atenção voluntária para o Grupo controle (GC) e Grupo Duchenne (GD).

Erros de inversão

Controle (GC)

Duchenne (GD)

\begin{tabular}{ccccccccc} 
atenção voluntária & Válida & Inválida & Neutra & Total & Válida & Inválida & Neutra & Total \\
\hline $\mathbf{1}$ & 0 & 0 & 1 & $\mathbf{1}$ & 2 & 1 & 0 & $\mathbf{3}$ \\
$\mathbf{2}$ & 2 & 1 & 1 & $\mathbf{4}$ & 1 & 3 & 1 & $\mathbf{5}$ \\
$\mathbf{3}$ & 0 & 0 & 0 & $\mathbf{0}$ & 0 & 1 & 0 & $\mathbf{1}$ \\
$\mathbf{4}$ & 0 & 0 & 0 & $\mathbf{0}$ & 0 & 3 & 0 & $\mathbf{3}$ \\
$\mathbf{5}$ & 0 & 0 & 0 & $\mathbf{0}$ & 3 & 1 & 0 & $\mathbf{4}$ \\
$\mathbf{6}$ & 0 & 0 & 2 & $\mathbf{2}$ & 1 & 1 & 0 & $\mathbf{2}$ \\
$\mathbf{7}$ & 0 & 0 & 0 & $\mathbf{0}$ & 1 & 2 & 0 & $\mathbf{3}$ \\
$\mathbf{8}$ & 0 & 0 & 0 & $\mathbf{0}$ & 1 & 0 & 0 & $\mathbf{1}$ \\
$\mathbf{9}$ & 3 & 0 & 1 & $\mathbf{4}$ & 0 & 7 & 0 & $\mathbf{7}$ \\
$\mathbf{1 0}$ & 0 & 0 & 0 & $\mathbf{0}$ & 2 & 2 & 1 & $\mathbf{5}$ \\
$\mathbf{1 1}$ & 0 & 1 & 0 & $\mathbf{1}$ & 3 & 3 & 3 & $\mathbf{9}$ \\
$\mathbf{1 2}$ & 1 & 1 & 0 & $\mathbf{2}$ & 3 & 1 & 0 & $\mathbf{4}$ \\
$\mathbf{1 3}$ & 0 & 0 & 1 & $\mathbf{1}$ & 0 & 1 & 0 & $\mathbf{1}$ \\
$\mathbf{1 4}$ & 2 & 2 & 0 & $\mathbf{4}$ & 4 & 6 & 1 & $\mathbf{1 1}$ \\
$\mathbf{1 5}$ & 3 & 0 & 1 & $\mathbf{4}$ & 0 & 0 & 0 & $\mathbf{0}$ \\
$\mathbf{1 6}$ & 1 & 0 & 1 & $\mathbf{2}$ & 1 & 1 & 0 & $\mathbf{2}$ \\
$\mathbf{1 7}$ & 1 & 0 & 2 & $\mathbf{3}$ & 0 & 1 & 0 & $\mathbf{1}$ \\
$\mathbf{1 8}$ & 1 & 1 & 0 & $\mathbf{2}$ & 1 & 2 & 0 & $\mathbf{3}$ \\
$\mathbf{1 9}$ & 0 & 0 & 0 & $\mathbf{0}$ & 0 & 2 & 0 & $\mathbf{2}$ \\
$\mathbf{2 0}$ & 0 & 0 & 1 & $\mathbf{1}$ & 0 & 1 & 0 & $\mathbf{1}$ \\
$\mathbf{2 1}$ & 2 & 0 & 0 & $\mathbf{2}$ & 6 & 0 & 0 & $\mathbf{6}$ \\
$\mathbf{2 2}$ & 1 & 0 & 2 & $\mathbf{3}$ & 0 & 1 & 0 & $\mathbf{1}$ \\
$\mathbf{2 3}$ & 2 & 0 & 0 & $\mathbf{2}$ & 1 & 1 & 1 & $\mathbf{3}$ \\
$\mathbf{2 4}$ & 2 & 3 & 2 & $\mathbf{7}$ & 0 & 0 & 0 & $\mathbf{0}$ \\
$\mathbf{2 5}$ & 0 & 0 & 0 & $\mathbf{0}$ & 1 & 2 & 1 & $\mathbf{4}$ \\
\hline Total & 21 & 9 & 15 & $\mathbf{4 5}$ & 31 & 43 & 8 & $\mathbf{8 2}$ \\
\hline Média & 0,84 & 0,36 & 0,6 & $\mathbf{1 , 8}$ & 1,24 & 1,72 & 0,32 & $\mathbf{3 , 2 8}$ \\
E.p.m. & 0,21 & 0,15 & 0,15 & $\mathbf{0 , 3 6}$ & 0,31 & 0,34 & 0,14 & $\mathbf{0 , 5 5}$ \\
\hline & & & & & & & & \\
\hline
\end{tabular}


Tabela 6.9. Idades e efeito atencional no teste de atenção voluntária para o Grupo Duchenne (GD).

\section{Efeito Atencional}

\begin{tabular}{cccc} 
DMD & Idade & Automático & Voluntário \\
\hline $\mathbf{1}$ & 11 & 104 & 105 \\
$\mathbf{2}$ & 12 & 82 & 217 \\
$\mathbf{3}$ & 11 & 89 & 132 \\
$\mathbf{4}$ & 16 & 49 & 25 \\
$\mathbf{5}$ & 11 & 49 & 62 \\
$\mathbf{6}$ & 10 & 4 & 138 \\
$\mathbf{7}$ & 11 & 63 & 62 \\
$\mathbf{8}$ & 10 & -46 & 72 \\
$\mathbf{9}$ & 15 & 93 & 38 \\
$\mathbf{1 0}$ & 16 & 78 & 59 \\
$\mathbf{1 1}$ & 11 & 13 & 95 \\
$\mathbf{1 2}$ & 11 & 55 & 137 \\
$\mathbf{1 3}$ & 14 & 73 & 82 \\
$\mathbf{1 4}$ & 11 & 14 & 229 \\
$\mathbf{1 5}$ & 10 & 100 & 34 \\
$\mathbf{1 6}$ & 15 & 48 & 17 \\
$\mathbf{1 7}$ & 16 & 80 & 0 \\
$\mathbf{1 8}$ & 11 & 63 & 29 \\
$\mathbf{1 9}$ & 12 & 89 & 112 \\
$\mathbf{2 0}$ & 15 & 76 & 15 \\
$\mathbf{2 1}$ & 10 & 83 & 37 \\
$\mathbf{2 2}$ & 10 & 64 & 20 \\
$\mathbf{2 3}$ & 10 & 5 & 141 \\
$\mathbf{2 4}$ & 11 & 102 & 41 \\
$\mathbf{2 5}$ & 11 & 69 & 125 \\
\hline & & &
\end{tabular}

